\title{
CENOMANIAN AMMONITES FROM THE CONDENSED DEPOSITS OF THE HELVETIC DOMAIN (WESTERN ALPS, FRANCE AND SWITZERLAND)
}

\author{
M. DELAMETTE AND W. J. KENNEDY \\ Institut de Géologie, Université de Fribourg, Pérolles, 1700 Fribourg, Switzerland and \\ Geological Collections, University Museum, Parks Road, Oxford OX1 3PR, United Kingdom
}

\begin{abstract}
The Cenomanian ammonites of the Helvetic Domain (French-Swiss Western Alps) are revised and illustrated for the first time since the middle of the Nineteenth Century. The faunas occur in remarkable condensed hemipelagic glauconite-rich biomicrites that also contain planktic foraminifera and small stromatolites. Thirty-three ammonite species referred to 15 genera are described; the assemblage extends from the lower part of the Lower Cenomanian Mantelliceras mantelli Zone (Neostlingoceras carcitanense Subzone) to the lower part of the Middle Cenomanian Acanthoceras rhotomagense Zone (Turrilites costatus Subzone). The assemblage comprises 57 percent trachyostracous forms, 41 percent heteromorphs of the standard N.W. European sequence, and 2 percent leiostracous forms, which inhabited an external shelf biome. The biogeographic affinity of this fauna is essentially cosmopolitan (69 percent), but 31 percent of the specimens belong to the European Boreal biota, with no Tethyan taxa.
\end{abstract}

\section{INTRODUCTION}

$T^{1}$ HE AIM of the present paper is to describe the results of reinvestigation of the Cenomanian deposits of the Western External Alps between Chambéry (Savoie, France) and Sion (Valais, Switzerland) (Figure 1) in the southern part of the Helvetic Zone. During the Cretaceous, the Helvetic Domain connected the Jura Platform to the west to the Ultrahelvetic Basin to the east. From late Aptian to mid Cenomanian, thin (5-50 $\mathrm{m})$ siliciclastic and carbonate sediments, rich in glauconite and phosphorites, were deposited in the Helvetic area. These condensed deposits overlie shallow-water Urgonian Limestones (Barremian to early Aptian), and are overlain by the late Cenomanian to Santonian pelagic biomicrites of the Seewen Limestones. The Cenomanian deposits described here form the transition between the Albian phosphate-rich greensands (Lindars sandstones: Delamette, 1988) and the Turonian biomicrites.

\section{PREVIOUS WORKS}

The Cenomanian deposits of the Helvetic Domain were first mentioned by Brongniart (1822). On the basis of phosphatized faunas collected from the "Rochers des Fiz" (Plate Massif, HauteSavoie), he recognized Ammonites varians, now known to be a Lower Cenomanian Schloenbachia species. But the earliest illustrations of Cenomanian ammonites from the region were given twenty-five years later in the classic monographs of Pictet and Campiche (1858-1860) and Pictet and Renevier (1866). Most came from the famous outcrop at Cheville (Morcles Massif, Valais), described by Renevier (1866). At this time, the anomalous occurrence of Cenomanian ammonites mixed up with Upper Albian ones was the point of origin of a lengthy dispute about the stratigraphical position of the "Vraconian" faunas of early workers (see discussion in Breistroffer, 1940).

In spite of these early publications, the Cenomanian deposits in the Helvetic domain sank into oblivion for about half a century. During this time, a number of authors, probably misled by the thinness and patchy distribution of these deposits, introduced the concept of a Senonian transgression in the area, above Albian deposits (e.g., Revil, 1910-1913). In later publications (e.g., Tolun, 1948; Carozzi, 1951; Rosset, 1957; Charollais, 1966), Cenomanian planktonic foraminifers were identified together with ammonites, but no illustrations were given. Indeed, no general study of the Helvetic Cenomanian deposits and their faunas has been published this century.

\section{CHARACTERISTICS OF HELVETIC CENOMANIAN}

The Cenomanian of the Helvetic Zone is characterized by hemipelagic glauconitic biomicrites with phosphatic nodules, passing upwards into pelagic biomicrites rich in globotruncanids and calcisphaerulids. This succession is frequently interrupted by gaps and erosional unconformities extending from the early Cenomanian to the late Turonian. Three main facies can be recognized: 1) fossiliferous condensed glauconitic limestones: the Fiz Limestones (Delamette, 1988); 2) remanié conglomerates with a Cenomanian micritic matrix enclosing Albian ammonites as clasts: the Bargy Conglomerate; and 3) foraminiferal biomicrites without glauconite or phosphorite: the Cushmani Biomicrites.

The Fiz Limestones. - This facies ranges from a few centimeters up to three meters in thickness, and is biomicrite rich in coarse grains of black glauconite and sparse quartz grains (Figure 6.1). The biophase comprises calcisphaerulids (e.g., Bonetocardiella conoidea), globotruncanids, sparse benthic foraminifera (e.g., Lenticulina, Marsonella), and fragments of echinoderms. The macrofauna, more-or-less phosphatized, includes ammonites as described below, semi-infaunal echinoids ( $\mathrm{Ho}$ laster), rare unidentified belemnites, and the hydrozoan Parkeria (Delamette et al., 1983).

In most outcrops, the Fiz Limestones yield only Lower Cenomanian ammonites and overlie a phosphatic conglomerate yielding a condensed Upper Albian ammonite assemblage (Mortoniceras inflatum Zone and part of the Stoliczkaia dispar Zone; Figure 5.1). In the south of the Platé Massif (see Rochers des Fiz in Figure 2), however, they begin with a highly glauconitic biomicrite containing uppermost Albian ammonites such as Mariella bergeri (Brongniart, 1822) and Stoliczkaia of the dorsetensis group, mixed in with lowermost Cenomanian ammonites (Figure 5.2).

The Fiz Limestones are only present in an area comprising the massifs of Morcles, Dents du Midi, Haut-Giffre, Platé, and Aravis (Figure 1). Even within this area, these limestones have a patchy distribution because of local gaps. In fact, detailed correlation between outcrops show that these gaps represent no more than the ultimate evolution of increasing condensation. This lateral evolution is recorded by a progressive reduction of the thickness of the glauconitic biomicrites and the development of small stromatolites (Figure 5.3). In some outcrops, these microbial build-ups may characterize nearly all the Cenomanian 


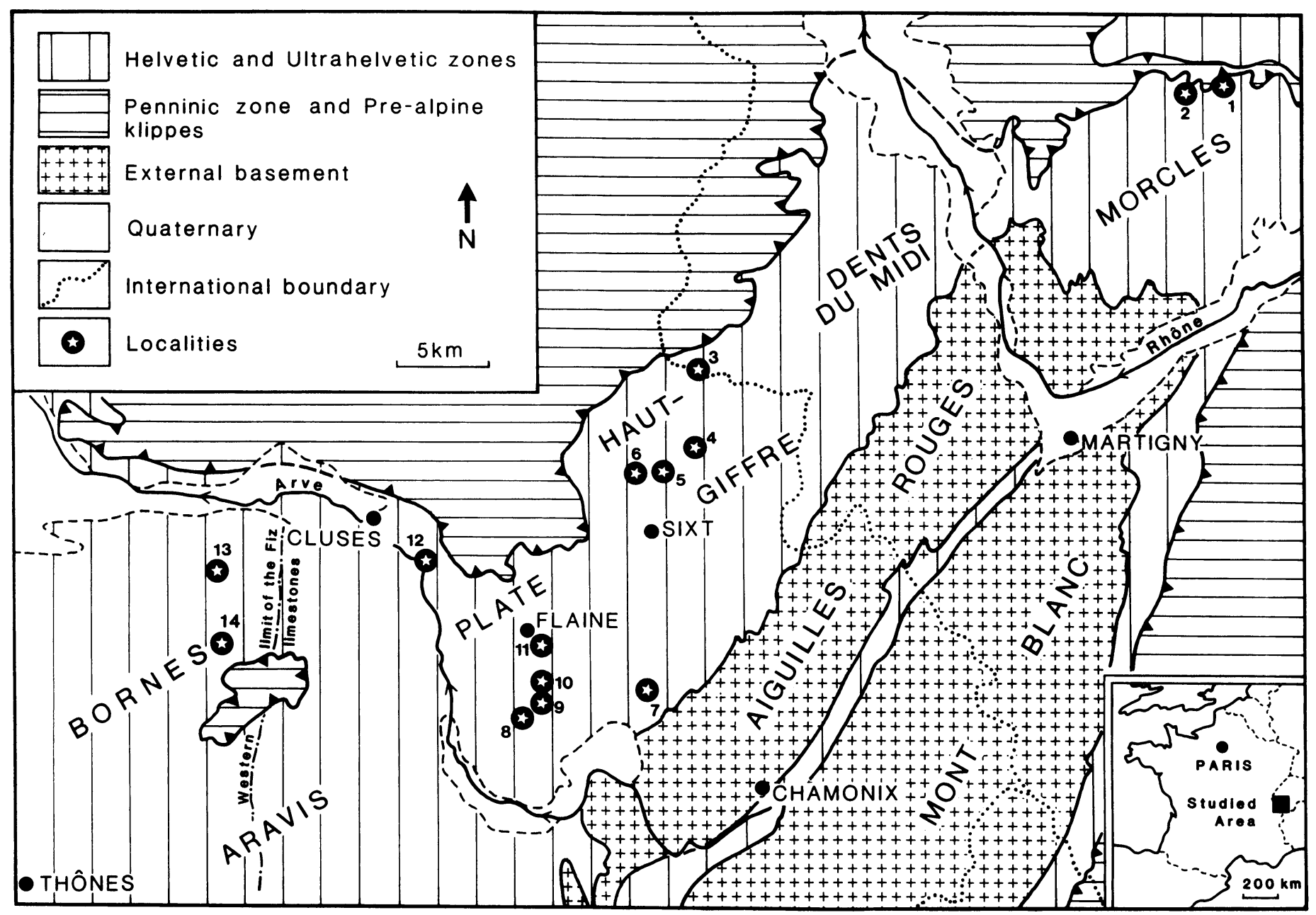

FIGURE $1-$ Geological sketch map of the study area, adapted from Gidon (1979), showing the location of the main Cenomanian fossiliferous sections mentioned in the text. 1, Cheville; 2, Ecuelle; 3, Lanche des Aux (=Bossetan of authors); 4, Avoudrues; 5, Pointe de l'Ecorchoir; 6, Chalets de Criou; 7, Rochers des Fiz; 8, Barmerousse; 9, Sautet; 10, Lindars; 11, Flaine; 12, Arberroz; 13, Bourgets (=Mt Saxonnet of authors); 14, Colombiere.

deposits (Figure 3). The ultimate expression of this condensation is recorded by the trapping of the Cenomanian biomicrites in Upper Albian cavernous phosphorites that are immediately overlain by Turonian biomicrites (Figures 4, 5.4).

The Bargy Conglomerate. - West towards Aravis, the Fiz Limestones disappear (see Figure 1), and the top of the midCretaceous deposits, overlain by Turonian biomicrites, is a polyzonal phosphatic conglomerate. This is usually highly fossiliferous, containing reworked Lower, Middle, and Upper Albian ammonites set in an uppermost Albian to Upper Cenomanian micritic matrix (Figure 5.5). Most of the fossils illustrated in the classic work of Pictet and Roux (1847-1854) were extracted from this conglomerate (e.g., the outcrops of Mont Saxonnet, Gaudonière, Reposoir). Detailed study shows that the passage from the Fiz Limestones to the Bargy Conglomerate is due to erosional unconformities cutting down into the Lindars Sandstones (see the Colombière section in Figure 2). On the basis of the microfaunal content of the matrix, the first reworking of Albian phosphatic sediment took place at the end of the Albian (top of the appenninica Zone) and persisted in some places until the Turonian (helvetica Zone).

The Cushmani Biomicrites. - The mid-Cretaceous glauconitic and phosphatic deposits are usually overlain by the Turonian biomicrites of the Seewen Limestones. But in some places (especially in the northeastern part of the area studied here) the base of the Seewen Limestones is older and belongs to the cushmani Zone (Figure 6.5). The distribution of these biomicrites is very patchy. No logical sedimentary framework can be detected except for a better development from SW to NE, i.e., from the proximal to distal parts of the shelf.

\section{AMMONITE FAUNAS}

Age.-Ammonites from the Helvetic Cenomanian can be dated in terms of the standard zonation developed for the Anglo-Paris Basin, including the type area around Le Mans in Sarthe, France (Kennedy, 1984; Wright and Kennedy, 1984), as shown in Figure 7. Lower Cenomanian elements of the assemblage are generally phosphatized, and include indices of both the lower and upper subzones of the Mantelliceras mantelli Zone, as well as of the succeeding Mantelliceras dixoni Zone. At two outcrops, Cheville in the Morcles Massif and Arberroz in the Platé Massif, there are also unphosphatized representatives of the Middle Cenomanian, including the index and other member species of the lower Turrilites costatus Subzone of the Acanthoceras rhotomagense Zone. Tolun (1948) identified Middle to Upper Cenomanian ammonites, but we have seen no evidence for any 


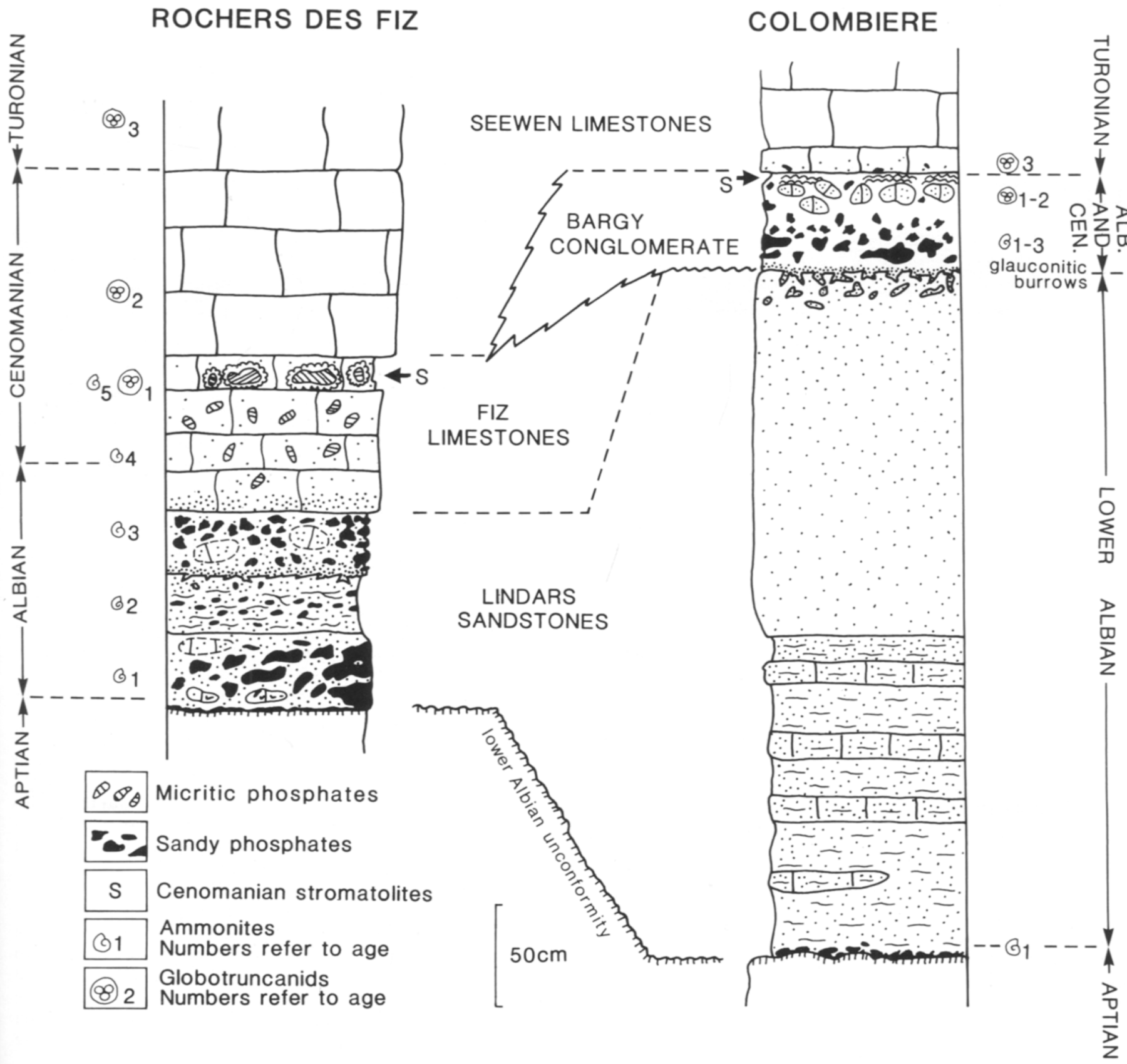

FIGURE 2-Two examples of the mid-Cretaceous succession in the Helvetic domain to show the position and facies of the Cenomanian deposits. With respect to ammonites, 1 = late jacobi(?) and tardefurcata Zones, $2=$ late mammillatum and early dentatus Zones, $3=$ inflatum and part of dispar Zones, 4 = late dispar and mantelli-dixoni Zones, $5=$ dixoni Zone (?). With respect to globotruncanids, $1=$ brotzeni and reicheli Zones, 2 = cushmani Zone, 3 = helvetica Zone.

ammonites younger than the costatus Subzone. The Fiz Limestones therefore represent, when complete, a highly condensed unit extending from Upper Albian Stoliczkaia dispar Zone (Rochers de Fiz) to the lower part of the Middle Cenomanian Acanthoceras rhotomagense Zone (Cheville, Arberroz). At most outcrops, however, it yields only Lower Cenomanian ammonites resting on, and terminated by, unconformities. The fauna described below is: Puzosia (Puzosia) mayoriana (d'Orbigny, 1841), Hyphoplites curvatus curvatus (Mantell, 1822), H. curvatus pseudofalcatus (Semenov, 1899), Hyphoplites curvatus ar- ausionensis (Hébert and Munier-Chalmas, 1875), Schloenbachia varians (J. Sowerby, 1817), Forbesiceras largilliertianum (d'Orbigny, 1841), Forbesiceras beaumontianum (d'Orbigny, 1841), Forbesiceras chevillei (Pictet and Renevier, 1866), Mantelliceras mantelli (J. Sowerby, 1814), Mantelliceras cantianum Spath, 1926a, Mantelliceras picteti Hyatt, 1903, Mantelliceras couloni (d'Orbigny, 1850), Mantelliceras saxbii (Sharpe, 1857), Mantelliceras lymense (Spath, 1926b) Mantelliceras dixoni Spath, 1926b, Sharpeiceras laticlavium (Sharpe, 1855), Sharpeiceras schlueteri (Hyatt, 1903), Acompsoceras sp., Acanthoceras rho- 


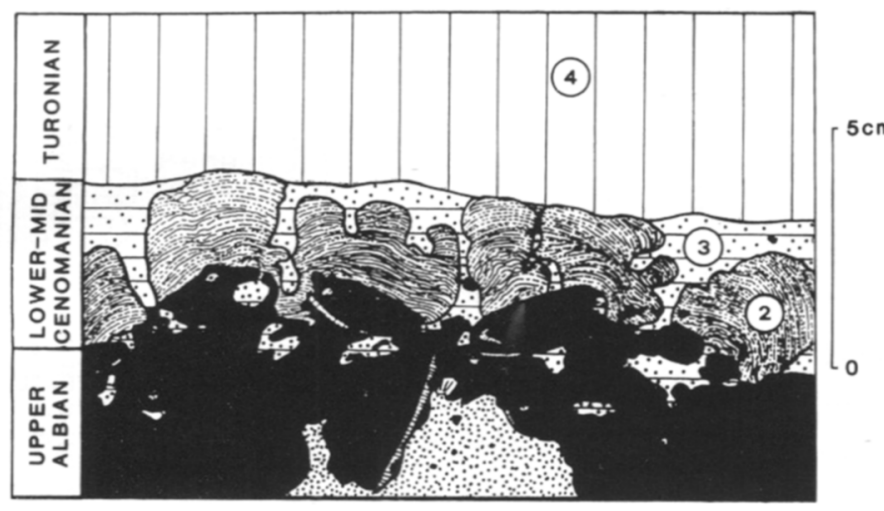

FIGURE 3-Highly condensed Cenomanian deposits (2, 3) lying between Upper Albian phosphatic conglomerate (1) and Turonian pelagic biomicrite (4). 2, small stromatolites encrusting the bioeroded top of the Albian phosphorites and 3, a glauconitic biomicrite with Lower Cenomanian globotruncanids (e.g., Rotalipora brotzeni) (drawn from a polished slab from Grandes-Platières in the Platé Massif).

tomagense (Brongniart, 1822), Cunningtoniceras cunningtoni (Sharpe, 1855), Cunningtoniceras inerme (Pervinquière, 1907), Anisoceras cf. perarmatum Pictet and Campiche, 1861, Anisoceras cherixi Pictet and Renevier, 1866, Turrilites (Turrilites) costatus Lamarck, 1801, Turrilites (Turrilites) scheuchzerianus Bosc, 1801, Neostlingoceras carcitanense (Matheron, 1842), $\mathrm{Hy}$ poturrilites gravesianus (d'Orbigny, 1842), $H$. gravesianus betaitraensis Collignon, 1964, Hypoturrilites sp., Mariella (Mariella) cf. gallienii (Boule, Lemoine and Thévenin, 1906), M. (M.) sp. a, Sciponoceras roto Cieśliński, 1959, S. baculoide (Mantell, 1822), and Scaphites (Scaphites) obliquus J. Sowerby, 1813.

Biogeographic affinities. - More than 300 specimens were identified during the course of this study, and these form the basis for the quantitative generic composition given in Table 1 .

The Cenomanian ammonite assemblage of the Helvetic domain is thus dominated by trachyostracous forms (57 percent) and heteromorphs (41 percent), whereas leiostracous forms are practically missing ( 2 percent, exclusively desmoceratids). Taking into account the accompanying faunas (virtually monospecific macrobenthos, pelagic hydrozoans), the ammonite assemblage is clearly related to an external shelf biome. It has a distinctive composition characterized by the abundance of heteromorphs, especially turrilitids (17.6 percent) and baculitids (12.7 percent). The same trend was noted by Juignet and Kennedy (1976) in Cenomanian condensed levels in the Anglo-Paris Basin.

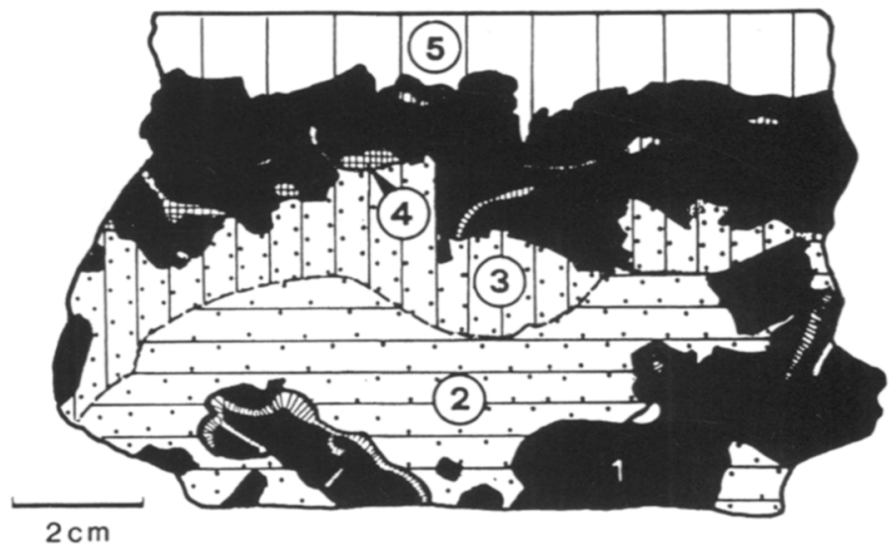

FIGURE 4-Cenomanian internal sediments (2-4) trapped in an Upper Albian phosphatic crust (1) immediately overlain by Turonian biomicrite (5). 2, 3, glauconitic biomicrites with different phosphate contents; 4 , void-filling sparry calcite at the top of the cavernous phosphorite. (Drawn from a polished slab from Grand-Grenier in the Platé Massif.)

In terms of biogeographic affinities, abundance of Schloenbachia ( 28 percent) places the fauna within the northwest European hoplitid province, with strong links with faunas of the Anglo-Paris Basin, the Germanies, the southern USSR and northern Iran (Juignet and Kennedy, 1976, fig. 20). During the Cenomanian, the Helvetic area was thus located in the southern part of the European Boreal Realm. Mediterranean influences, although well marked in the Upper Albian ammonite assemblages of the area (Delamette, 1988), are weak in the Cenomanian (few desmoceratids and a lack of phylloceratids, gaudryceratids, and tetragonitids). This Boreal Cenomanian ammonite influx could be related to the cooling phase at the end of the Albian indicated by isotopic analyses from the Briançonnais domain (Bourbon, 1980), as could the post-Albian decline of presumably stenothermal Mediterranean ammonites in the Cenomanian assemblage of the Helvetic Domain.

\section{PLANKTIC FORAMINIFERA}

In contrast to ammonites, which are only preserved in the Fiz Limestones, planktic foraminifera are present in all three facies recognized, and include indices of the standard zonal scheme (Figure 7). Because of the strong condensation of the Cenomanian deposits in the Helvetic Domain, the distinction between brotzeni and reicheli Zones was not possible because

FIGURE 5-Facies of the Cenomanian deposits in the southern part of the Helvetic Domain. 1, stratigraphic position of the Fiz Limestones (D) at Lindars in the Plate Massif, Haute-Savoie. A = Middle Albian argillaceous sandstones. B = Upper Albian sandstones with glauconitic Thalassinoides. $\mathrm{C}=$ polyzonal phosphatic conglomerate (Mortoniceras inflatum and Stoliczkaia dispar Zones). D = Fiz Limestones: glauconitic biomicrites with stromatolites at the top (Mantelliceras mantelli and $M$. dixoni Zones). $\mathrm{E}=$ Turonian pelagic biomicrites (Helvetoglobotruncana helvetica Zone). Note the lack of Rotalipora cushmani Zone fossils between bed D and bed E. Scale given by the altimeter, which is $5 \mathrm{~cm}$ in diameter. 2, base of the Fiz Limestones at the type-locality, the Rochers des Fiz in the Plate Massif, Haute-Savoie: glauconitic biomicrites with phosphatized ammonites of the uppermost Albian $(\mathrm{A}=$ Stoliczkaia $\mathrm{sp}$.) and of the Lower Cenomanian $(\mathrm{B}=S$ chloenbachia varians $)$. Lens cap is $5 \mathrm{~cm}$ in diameter. 3, top of the Fiz Limestones at the type-locality: an accumulation of phosphatized ammonites (mainly Mantelliceras) is encrusted by stromatolites. View parallel to the stratification. 4, highly condensed Cenomanian deposits at Flaine in the Platé Massif, HauteSavoie. These deposits are represented by small stromatolites (black arrows) encrusting the irregular top of the Upper Albian phosphatic crust and by biomicrites trapped in the cavities of the phosphatic crust (white arrows). The uppermost white level is Turonian pelagic biomicrite. 5. Bargy Conglomerate at La Gaudinière in the Bornes Massif, Haute-Savoie. A = Lower to Upper Albian phosphatic nodules, B = Upper Albian lag-nodules, $\mathrm{C}=$ Cenomanian glauconitic biomicrites, $\mathrm{D}=$ overturned Cenomanian stromatolites, $\mathrm{E}=$ Turonian pelagic biomicrites. Bar scale is $10 \mathrm{~cm}$. 

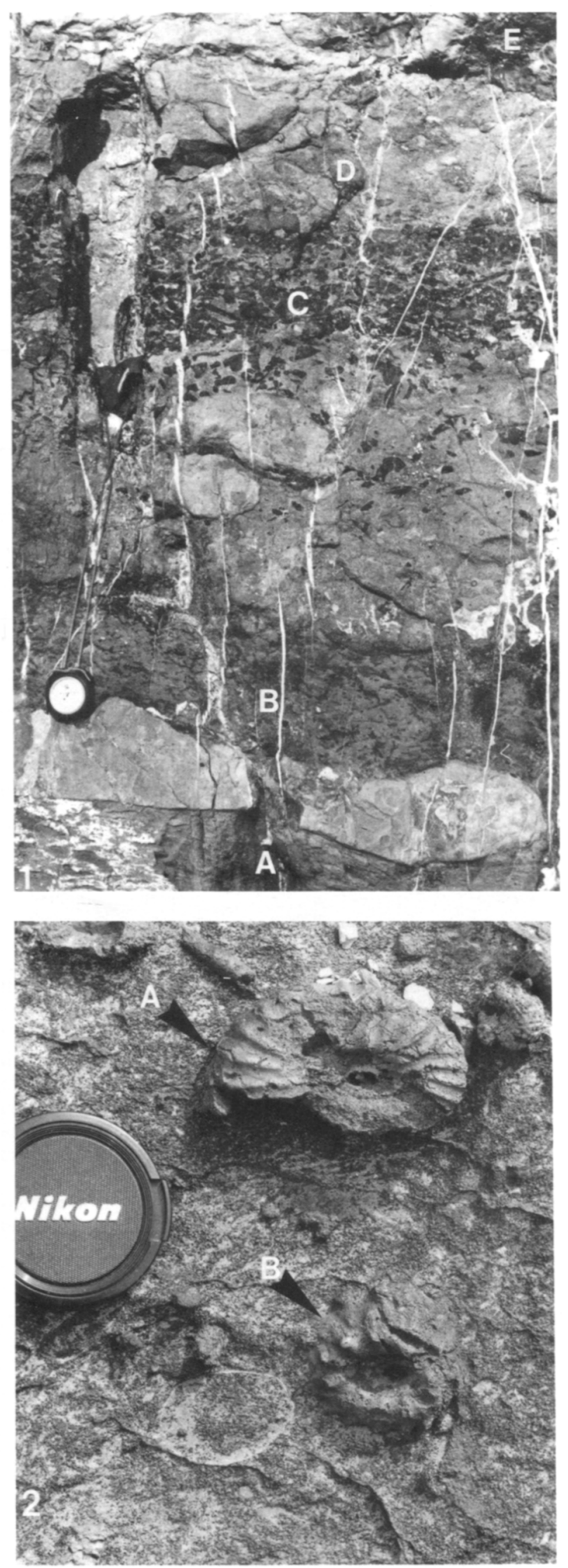
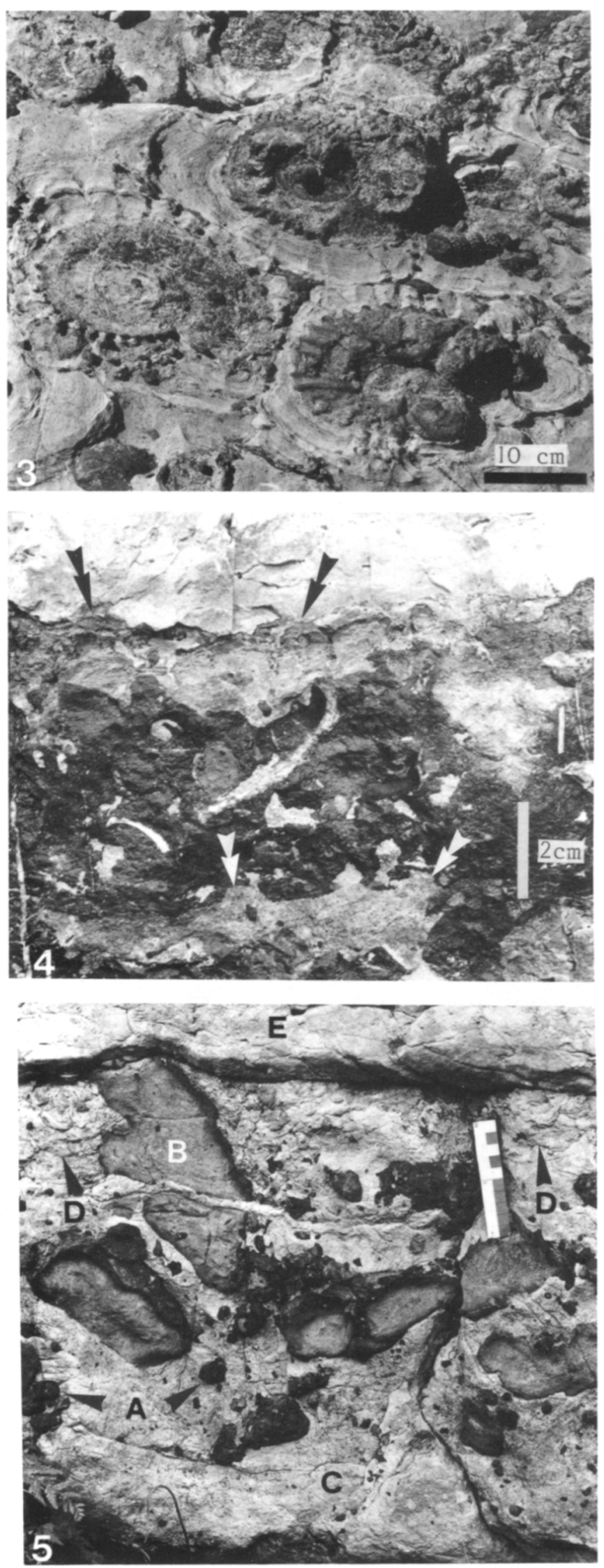

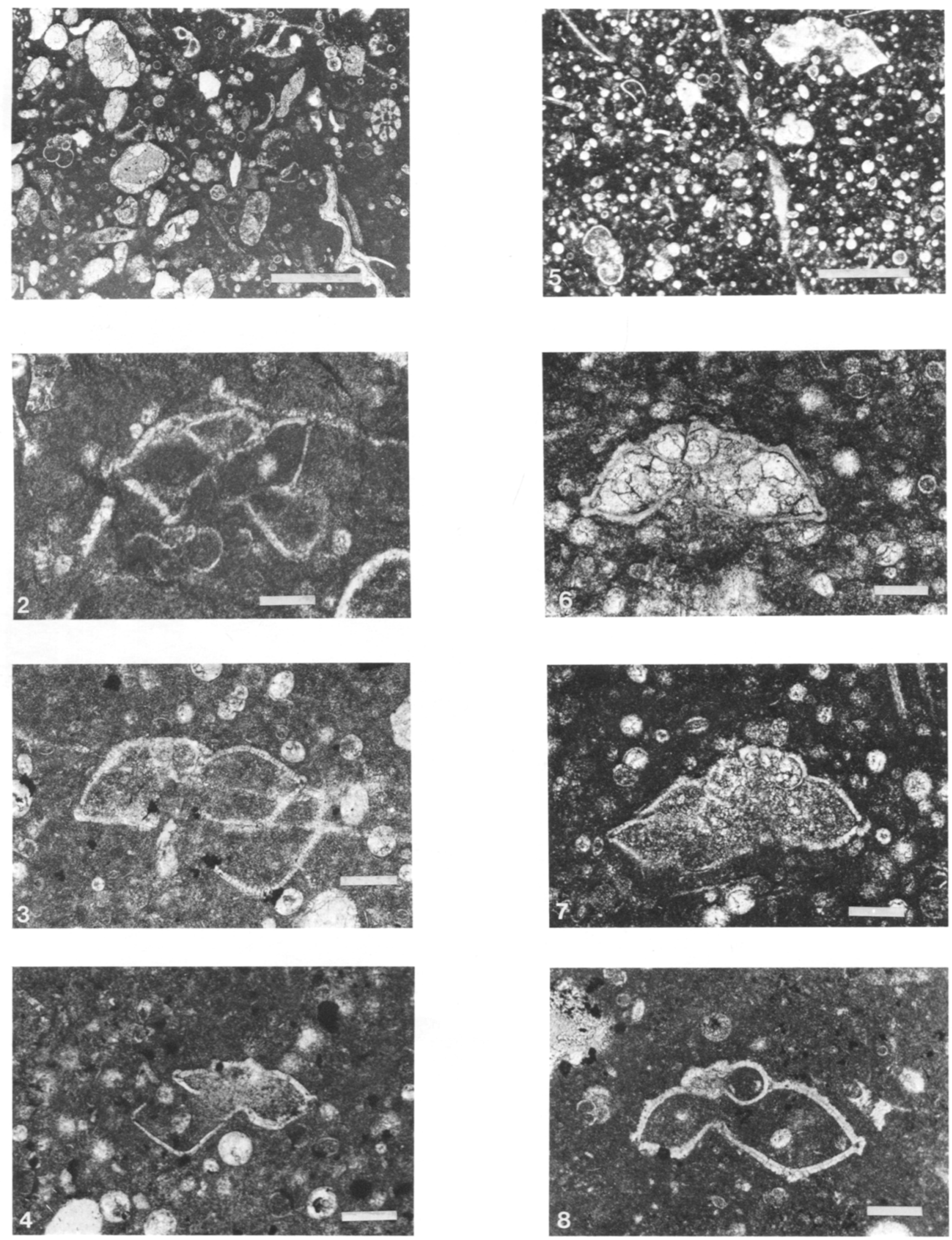


\begin{tabular}{|c|c|c|c|}
\hline $\begin{array}{l}\text { SUB- } \\
\text { STAGE }\end{array}$ & AMMONITE ZONE & AMMONITE SUBZONE & GLOBOTRUNCANID ZONE \\
\hline \multirow{2}{*}{ 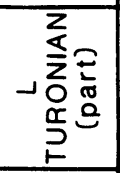 } & \multirow{2}{*}{ Watinoceras coloradoense } & & $\begin{array}{c}\text { Praeglobotruncana helvetica } \\
\text { (part) }\end{array}$ \\
\hline & & & \multirow[b]{2}{*}{ Whiteinella archaeocretacea } \\
\hline \multirow{3}{*}{ 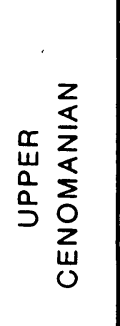 } & Neocardioceras juddii & & \\
\hline & Metoicoceras geslinianum & & \multirow{4}{*}{ Rotalipora cushmani } \\
\hline & Calycoceras guerangeri & & \\
\hline \multirow{3}{*}{ 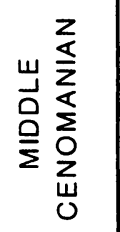 } & Acanthoceras jukesbrownei & & \\
\hline & \multirow{2}{*}{ Acanthoceras rhotomagense } & Turrilites acutus & \\
\hline & & Turrilites costatus & Rotalipora reicheli \\
\hline \multirow{3}{*}{ 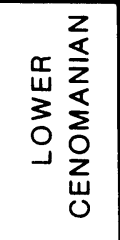 } & Mantelliceras dixoni & & \multirow{3}{*}{ Rotalipora brotzeni } \\
\hline & \multirow{2}{*}{ Mantelliceras mantelli } & Mantelliceras saxbii & \\
\hline & & Neostlingoceras carcitanense & \\
\hline 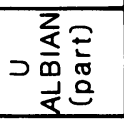 & Stoliczkaia dispar & & \\
\hline
\end{tabular}

FIGURE 7-Ammonite zones and subzones and globotruncanid zones applied in the Helvetic Domain.

the diagnostic species of these two zones are always mixed together. In the Bargy Conglomerate, marker species of all the Cenomanian globotruncanid zones may co-occur (Figure 2), although cushmani and archaeocretacea Zone forms are often absent. In some outcrops (Rochers de Fiz: see Figure 2) the cushmani biomicrites form the base of the Seewen Limestones and overlie the condensed brotzeni-reicheli glauconitic biomicrites.

Where planktic forams were identified in the infillings of ammonite phragmocones, the age given by these microfaunal markers is the same as that of the ammonites. For instance, Rotalipo- ra reicheli was identified in the matrix of a Cunnintoniceras (Figure 6.2).

\section{ACKNOWLEDGMENTS}

The authors offer sincere thanks to D. Decrouez (Museum of Natural History of Geneva) and to S. M. Weidmann and A. Baud (Geological Museum of Lausanne) who have allowed us to study the old collections. Special thanks are due to M. Caron (University of Fribourg) for her help in the determination of the planktic foraminifers. For one of us (M.D.) this paper has been written under a research agreement of the Swiss Science

FIGURE 6-Microfacies and planktic foraminifers of the Cenomanian in the southern part of the Helvetic Domain. 1, microfacies of the Fiz Limestones: slightly phosphatized biomicrites with more-or-less calcitized coarse glauconite grains, calcisphaerulids, globotruncanids, and echinoderm debris. Bar scale is $1 \mathrm{~mm}$. Thin section MD 2158a, from the Montagne de Chérente, Aravais Massif, Haute-Savoie. 2-4, rotaliporids from the Fiz Limestones (bar scales are $100 \mu \mathrm{m}) .2$, Rotalipora cf. reicheli trapped in the phosphatized infill of a Middle Cenomanian ammonite (Cunningtoniceras inerme, from the Acanthoceras rhotomagense Zone). Thin section MD 1336, from Cheville, Morcles Massif, Valais. 3, Rotalipora cf. montsalvensis trapped in a stromatolite. Thin section MD 2988, from Arberroz, in the Platé Massif, Haute-Savoie. 4, Rotalipora appenninica, locality as for 3. 5, microfacies of the Cushmani Biomicrites: calcisphaerulid-rich biomicrites with Rotalipora cushmani. Bar scale is $100 \mu \mathrm{m}$. Thin section MD 2306 from the Combes aux Puaires, Haut-Giffre Massif, Haute-Savoie. 6-8, rotaliporids from the Cushmani Biomicrites (bar scales are $100 \mu \mathrm{m}$ ). 6, Rotalipora cushmani, thin section MD 2303, locality as for 5. 7, Rotalipora cf. gandolfi, thin section MD 2683, from the Fenêtres à Grappins, Haut-Giffre Massif, Haute-Savoie. 8, Rotalipora cf. montsalvensis, thin section MD 3082, from the Montagne de Foillis, Haut-Giffre Massif, Haute-Savoie. 
TABLE 1-Composition, in percent, of Helvetic Domain Cenomanian ammonite faunas.

\begin{tabular}{lr}
\hline \hline Hyphoplites: & \\
Schloenbachia: & 2.5 \\
Mantelliceras: & 28.5 \\
Sharpeiceras: & 16.5 \\
Acanthoceras: & 0.9 \\
Cunningtoniceras: & 0.3 \\
Acompsoceras: & 6.2 \\
Forbesiceras: & 0.3 \\
Puzosia: & 0.9 \\
Mariella: & 1.9 \\
Hypoturrilites: & 4.0 \\
Neostlingoceras: & 7.1 \\
Turrilites: & 6.2 \\
Scaphites: & 10.3 \\
Sciponoceras: & 0.6 \\
\hline
\end{tabular}

Foundation, project $N^{\circ} 2.408 .0-84$. Kennedy acknowledges the financial support of the Natural Environment Research Council (U.K.), and the technical assistance of the staff of the Geological Collections, Oxford University Museum and Department of Earth Sciences, Oxford.

\section{REPOSITORIES OF SPECIMENS}

BMNH: British Museum (Natural History), London; EMP: collections of the École des Mines, Paris, now in the Universite Claude Bernard, Lyon; GSM: British Geological Survey and Museum collections, Keyworth; MGL: Musée de Géologie, Lausanne (Renevier and Collet collections); MHNG: Muséum d'Histoire Naturelle, Geneva (Pictet, Favre, Tolun, Jayet, and Delamette collections); MNHP: Muséum National d'Histoire Naturelle, Paris; SP: collections of the Sorbonne, now in the Université Pierre et Marie Curie, Paris.

\section{SYSTEMATIC PALEONTOLOGY}

Superfamily DESMOCERATACEAE Zittel, 1895

Family DeSMOCERATIDAE Zittel, 1895

Family Puzosinae Spath, 1922a

Genus Puzosia Bayle, 1878

Subgenus Puzosia (Puzosia) Bayle, 1878

Type species. - Ammonites planulatus J. de C. Sowerby, 1827 , p. 134, Pl. 570, fig. 5, non Schlotheim, 1820, p. $59=$ Ammonites mayorianus d'Orbigny, 1841 , p. $267, \mathrm{Pl}$. 79, figs. 1-3. Wright and Kennedy $(1984$, p. 54) clarified the name of the type species.

Puzosia (Puzosia) mayoriana (d'Orbigny, 1841) Figure 8.26

Ammonites planulatus J. DE C. SOWERBY, 1827, p. 597, Pl. 570, fig. 5 (non Schlotheim, 1820, p. 59).

Ammonites Mayorianus D'OrBIGNY, 1841, p. 267, PI. 79, figs. 1-3.

Puzosia (Puzosia) mayoriana (d’Orbigny). WRIGHT AND KENNEDY, 1984, p. 55, Pl. 3, figs. 1, 2, 4, 6, 9-12, Pl. 4, figs. 1, 2, 5-7, text-figs. 1A, $\mathrm{B}, 2 \mathrm{C}, \mathrm{H}, \mathrm{M}, 3 \mathrm{~N}-\mathrm{R}, 4 \mathrm{~A}-\mathrm{E}$ (with full synonymy); COOPER AND KENNEDY, 1987, p. 106, figs. 1-7, 9, 10.

Puzosia (Puzosia) cf. subplanulata (Schlüter, 1871). IMMEL AND SEYEDEMAMI, 1985, p. 91.
Lectotype.-By the subsequent designation of Wright and Wright (1951, p. 35): BMNH C9381, from the Lower Chalk of Hamsey near Lewes, Sussex. This specimen was designated lectotype of planulatus of J. de. C. Sowerby for which d'Orbigny proposed mayorianus as replacement name. See Wright and Kennedy $(1984$, p. 56) for clarification.

Collection. - Two specimens, MGL 42895, the original of Pictet and Renevier (1866, Pl. 4, fig. 1) and MGL 42894, both from Cheville.

Discussion. - Both specimens are distorted, but show coiling, whorl section, constrictions and ribbing typical of this species. Both appear to be incomplete macroconchs. Differences from other species are given by Wright and Kennedy (1984, p. 57).

Occurrence.-Upper Albian to Upper Cenomanian. In the Cenomanian there are records from many parts of Europe, Africa, southern India, and Japan.

\section{Superfamily Hoplitaceae H. Douvillé, 1890}

Family HoplitidaE H. Douvillé, 1890

Subfamily Hoplitinae H. Douvillé, 1890

Genus HYPHOPLITES Spath, 1922b

Type species. - By original designation: Ammonites falcatus Mantell, 1822, p. 117, Pl. 21 figs. 6, 12.

\section{HYPHOPLITES CURVATUS CURVATUS (Mantell, 1822)} Figures 8.1-8.5

Ammonites curvatus MANTEll, 1822, p. 118, Pl. 12, fig. 18; Pictet AND CAMPICHE, $1858-1860$ p. 210 (pars), Pl. 27, fig. 11 only.

Hyphoplites curvatus curvatus (Mantell). KENNEDY AND JUIGNET, 1984, p. 117, figs. 8k-n, 10a-c, 11 a-c; WrIGHT AND KENNEDY, 1984, p. 71, Pl. 7, figs. 1, 5, 6, 8-10, Pl. 18, figs. 2, 4, 8, 12, 14; text-figs. 6F-L, 9F-H (with full synonymy).

Hyphoplites curvatus (Mantell). IMMEL AND SEYED-EMANI, 1985, p. 93, Pl. 1, fig. 8.

Holotype. - By monotypy BMNH 5739, from the Lower Cenomanian Chalk Marl of Hamsey, near Lewes, Sussex, the original of Mantell, 1822, p. 118, Pl. 21, fig. 18.

Collections. - Four specimens: MHNG 19305 from the Rochers des Fiz, the original of Pictet and Campiche, 1858-1860, Pl. 27, fig. 11; MHNG 1295 from Arberroz, both in the Platé Massif, Haute-Savoie; MGL 42880 and 42881 , both from Cheville, Morcles Massif, Valais.

Discussion. - Hyphoplites curvatus curvatus is compressed and involute with prominent umbilical and inner and outer ventrolateral tubercles. Fine ribs link the umbilical bullae to the inner ventrolaterals, with some ribs extending into the interspaces between the inner ventrolaterals. It is easily separated from other members of the genus: $\boldsymbol{H}$. curvatus arausionensis (Hébert and Munier-Chalmas, 1875) is much more compressed, lacks prominent umbilical bullae, and has weak or no inner ventrolateral tubercles.

Occurrence.-The subspecies ranges throughout the Lower Cenomanian. It occurs widely in southern England, from Devon, Dorset, and Somerset to Kent and the Chilterns. In France it is known from the Boulonnais and Haute Normandie to Cassis (Bouches-du-Rhône). There are also records from the Germa-

FiguRE 8-1-5, Hyphoplites curvatus curvatus (Mantell, 1822). 1, 2, MHNG 1295; 3-5, MHNG 19305, the original of Pictet and Campiche, 1858-1860, Pl. 27, fig. 11. 6, Hyphoplites curvatus pseudofalcatus (Semenov, 1899), MHNG 1276. 7-20, 23, 24, 27-30, Schloenbachia varians (J. Sowerby, 1817). 7, 8, MHNG 1234; 9, MHNG 1245; 10, 11, MHNG 1248; 12, MHNG 1244; 13, 14, MHNG 1231; 15, 16, MHNG 19442, the holotype of Ammonites tollotianus Pictet, 1847, p. 109, Pl. 10, fig. 5; 17, MHNG 1246; 18, MHNG 1247; 19, 20, MHNG 1232; 23, 24, MHNG 1264; 27, 28, MHNG 1230; 29, 30, MHNG 1269. 21, 22, Forbesiceras beaumontianum (d'Orbigny, 1841), MHNG 1271. 25, Forbesiceras largilliertianum (d'Orbigny, 1841), MHNG 1270. 26, Puzosia (Puzosia) mayoriana (d’Orbigny, 1841), MLG 42895. All figures are natural size. 





nies, Transcaspia, the Crimea, and Kopet-Dag in the U.S.S.R. and Iran north of the Zagros.

\section{HYPHOPLITES CURVATUS PSEUDOFALCATUS \\ (Semenov, 1899)}

Figure 8.6

Hoplites pseudofalcatus SemENov, 1899, p. 129.

Hyphoplites curvatus pseudofalcatus (Semenov). KENNEDY AND JUIGNET, 1984, p. 118, figs. 3k-m, 8a, b, d-f; WRIGHT AND KENNEDY, 1984, p. 72, Pl. 6, fig. 7, Pl. 7, figs. 4, 7, 11, 13, Pl. 8, figs. 3, 5, 9, text-figs. 6A-E, 7A-D, 8C, 9K (with full synonymy).

Hyphoplites pseudofalcatus (Semenov). IMMEL AND SEYED-EMAMI, 1985, p. 91 , Pl. 1, fig. 3.

Lectotype.-By the subsequent designation of Wright and Wright, 1949 , p. 486 , the original of Sharpe, 1853, Pl. 7, fig. 5, from the Lower Cenomanian Chalk Marl of the Clayton Tunnel, Sussex. The original specimen is in the Brighton Museum (see Wright and Kennedy, 1984, Pl. 6, fig. 7).

Collection.-One specimen, MHNG 1276 from the Rochers des Fiz, Platé Massif, Haute-Savoie.

Discussion. - Although distorted, this specimen clearly belongs to the subspecies pseudofalcatus. It is much more compressed than $H$. curvatus curvatus, has much weaker umbilical bullae, and lacks an inner ventrolateral tubercle. The presence of an outer ventrolateral tubercle linking several of the fine falcoid ribs differentiates it from Hyphoplites costosus Wright and Wright, 1949.

Occurrence. - Rare in the Mantelliceras mantelli Zone of Devon, Dorset, the Isle of Wight, Wiltshire, Hampshire, Sussex, and Kent in England, Sarthe in France, Transcaspia and Kopet-Dag in the U.S.S.R., and Iran north of the Zagros.

\section{HYPHOPLITES CURVATUS ARAUSIONENSIS}

(Hébert and Munier-Chalmas, 1875)

Ammonites arausionensis Hébert AND MunIER-ChAlmAS, 1875, p. 115 , pars, Pl. 4, fig. 5 only.

Hyphoplites curvatus arausionensis (Hébert and Munier-Chalmas). Wright AND KENNEDY, 1984, p. 72, Pl. 8, figs. 1, 6, 7, 10, 11, 13 , 15,16 , Pl. 19, figs. 1-14, text-figs. $7 \mathrm{~L}-\mathrm{N}, 8 \mathrm{D}, 9 \mathrm{E}, \mathrm{J}, \mathrm{L}, \mathrm{M}$ (with full synonymy).

Hyphoplites arausionensis arausionensis (Semenov, 1899). IMMEL AND Seyed-Emani, 1985, p. 92, Pl. 1, fig. 5.

Hyphoplites arausionensis crassofalcatus (Semenov, 1899). IMMEL AND SeYed-EMAMI, 1985, p. 92, Pl. 1, fig. 6.

Hyphoplites arausionensis horridus Wright and Wright, 1951. IMMEL AND SeYed-EMami, p. 93, Pl. 1, fig. 7.

Lectotype. - The original of Hébert and Munier-Chalmas 1875 , Pl. 4, fig. 5, by the subsequent designation of Wright and Wright, 1949 , p. 491 , an unregistered specimen in the Sorbonne Collections, now in the Université Pierre et Marie Curie, Paris. From Gacé, Orne, France.

Collections. - Two specimens: MHNG 52474 from the Roches de Fiz and MHNG 52486 from Arberroz, both in the Platé Massif, Haute-Savoie.

Discussion. - Although too poorly preserved for illustration, these specimens show an ornament of strong umbilical tubercles, inner and outer ventrolateral clavi, linked by broad single ribs. Absence of fine ribs on the flank of the phragmocone readily distinguishes them from $H$. c. curvatus and $H$. c. pseudofalcatus, described above.
Occurrence. - This subspecies ranges throughout the Lower Cenomanian and has a wide geographic range, from Devon to Kent and the Chilterns in southern England to the Boulonnais, Normandie, Sarthe, Maine, and Provence in France, Transcaspia and the Kopet-Dag in the U.S.S.R., and Iran north of the Zagros.

\section{Family SchloENBACHIIDAE}

Parona and Bonarelli, 1897

Remarks. -For discussion see Kennedy et al., 1979, p. 28.

$$
\begin{gathered}
\text { Genus SCHLOENBACHIA Neumayr, } 1875 \\
\text { (=Hystrichoceras Hyatt, 1900; } \\
\text { Saltericeras Atabekian, 1960) }
\end{gathered}
$$

Type species. - By the subsequent designation of $\mathrm{H}$. Douvillé, 1890 (p. 290): Ammonites varians J. Sowerby, 1817, p. 169, Pl. 176.

Discussion. - The wide intraspecific variation shown by species of this genus is well known, following discussions by Juignet and Kennedy (1976), Kennedy et al. (1979), Marcinowski (1980), Hiss (1982), and Kennedy and Juignet (1984). Following these authors, only one species is recognized among the present collection: the Lower Cenomanian S. varians (J. Sowerby, 1817).

SCHLOENBaChIA VARIANS (J. Sowerby, 1817)

Figures 8.18-8.20, 8.23, 8.24, 8.27-8.30, 9.22

Ammonites varians J. SOWERBY, p. 169 (pars), Pl. 176, uppermost figure, figure in row below, right-hand figure in row below.

Ammonites varians var. subplana MANTELL, 1822, p. 166, Pl. 21 , fig. 2.

Ammonites varians var. intermedia MANTEl, 1822, p. 166, Pl. 21, figs. $5,7$.

Ammonites varians var. tettramata J. DE C. SOWERBY, 1828, p. 166, PI. 587, fig. 2.

Ammonites tollotianus Pictet, 1847, p. 109, Pl. 10, fig. 5.

Ammonites coupei var. inflata SHARPE, 1853 , p. 24 , Pl. 8 , fig. 1 (=S. ventriosa Stieler, 1922).

Schloenbachia ventriosa Stieler, 1922, p. 31.

Schloenbachia subvarians SPATH, 1926a, p. 81

Schloenbachia subvarians aperta SPATH, 1926b, p. 430.

Schloenbachia subvarians densicostata SPATH, 1926b, p. 430.

Schloenbachia ecarinata SPATH, 1928, p. 241.

Schloenbachia varians (J. Sowerby). KENNEDY AND JUIGNET, 1984, p. 123, figs. $11 \mathrm{k}, 1,12 \mathrm{a}-1,14 \mathrm{a}-\mathrm{g}, 15 \mathrm{a}-\mathrm{k}, 16 \mathrm{a}-\mathrm{l}, 17 \mathrm{a}-\mathrm{f}, 18 \mathrm{a}, \mathrm{b}$ (with full synonymy).

Lectotype. - by the subsequent designation of Spath, 1939, p. 544 , BMNH 43962b, the original of J. Sowerby, 1817, Pl. 176, top figure, reillustrated by Kennedy and Hancock, 1978, Pl. 3, fig. 1 .

Collections. - Seventy-three phosphatized specimens: MGL $8345 a, b, 8355 a, b, 8366,8368,43005,43006 a-e, 43007 a-c$, 43008a-d and MHNG 1244-1249, 19335a-d from Cheville, Morcles Massif, Valais; MHNG 1266, 1267, 1288, 19338 from the Chalets de Criou, Haute Giffre Massif, Haute-Savoie and MHNG 1272, 1273 from Barmerousse; MHNG 1230, 1232, 1234, 1254-1264 from Arberroz; MHNG 19336a, b, 1280, 1282, $1285,1328 \mathrm{a}, \mathrm{b}, 1333,1335,1339 \mathrm{a}-\mathrm{f}$ from the Rochers des Fiz; MHNG 1265, 1268, 1269, 1331 from Lindars; MHNG 19442, the holotype of Ammonites tollotianus Pictet, 1847, p. 109, Pl. 10, fig. 5, from Flaine, Platé Massif, Haute-Savoie.

FIGURE 9-1-3, Forbesiceras chevillei (Pictet and Renevier, 1866), holotype, MGL 8402. 4-6, 19-21, Mantelliceras mantelli (J. Sowerby, 1814). 4-6, MHNG 1240; 19, MHNG 19379; 20, 21, MHNG 19401. 7, 8, 11-18, Mantelliceras couloni (d'Orbigny, 1850). 7, 8, MHNG 1239; 11, 12, 18, MHNG 1322; 13, 14, MHNG 1238; 15-17, MHNG 1237.9, 10, Sharpeiceras laticlavium(Sharpe, 1855), MHNG 1222. 22, Schloenbachia varians (J. Sowerby, 1817), MHNG 1268. All figures are natural size. 


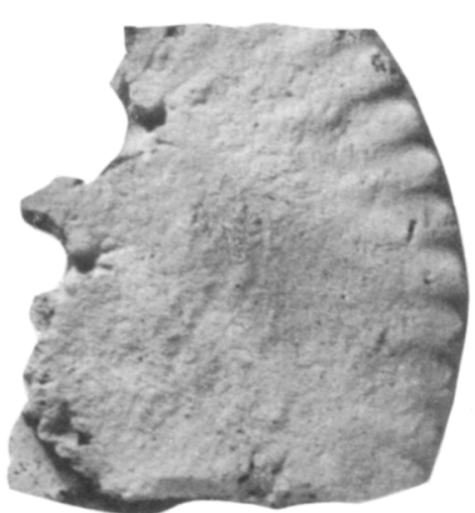

1

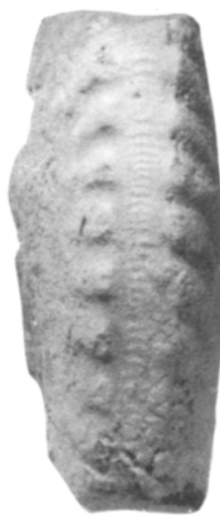

2
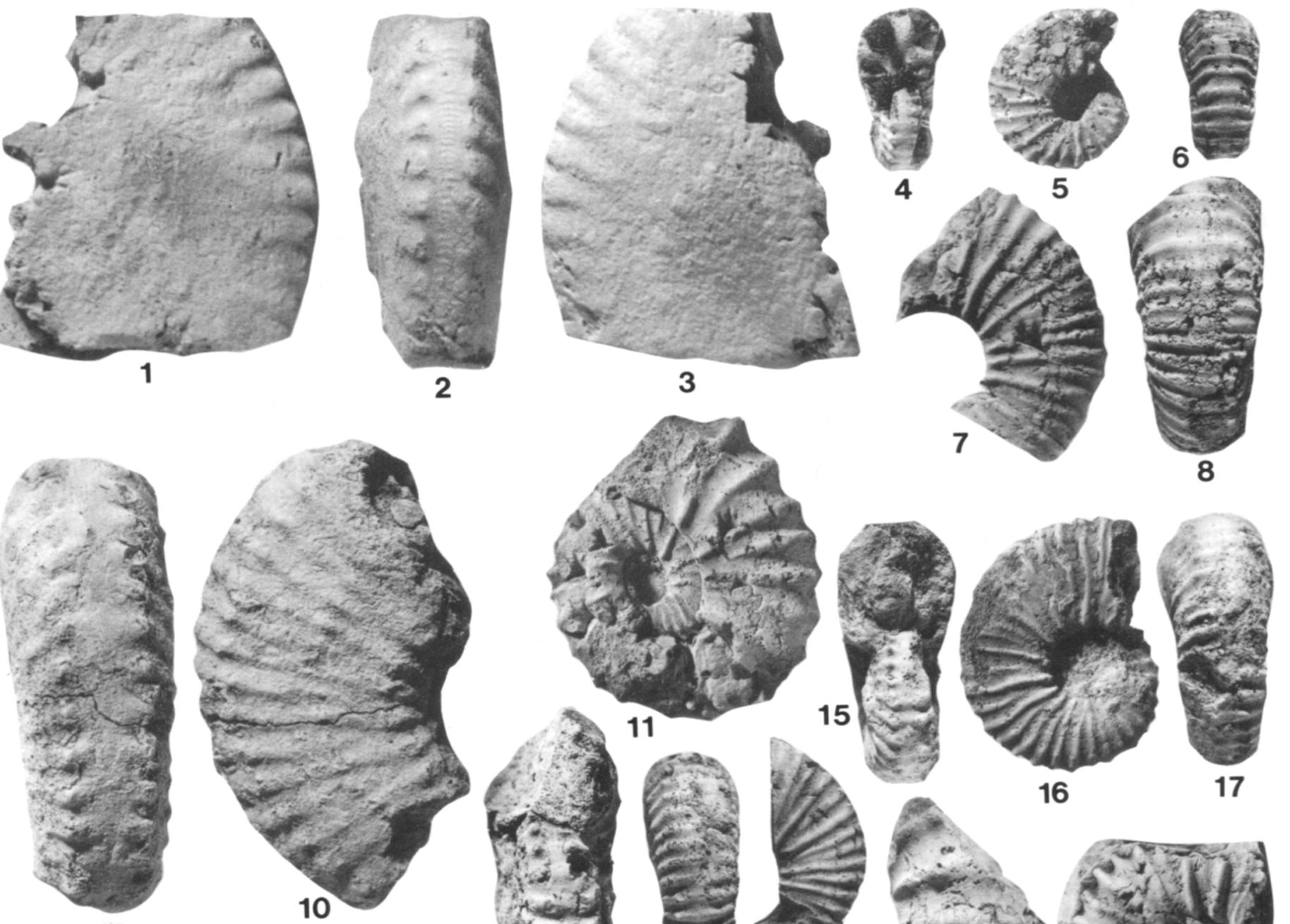

9
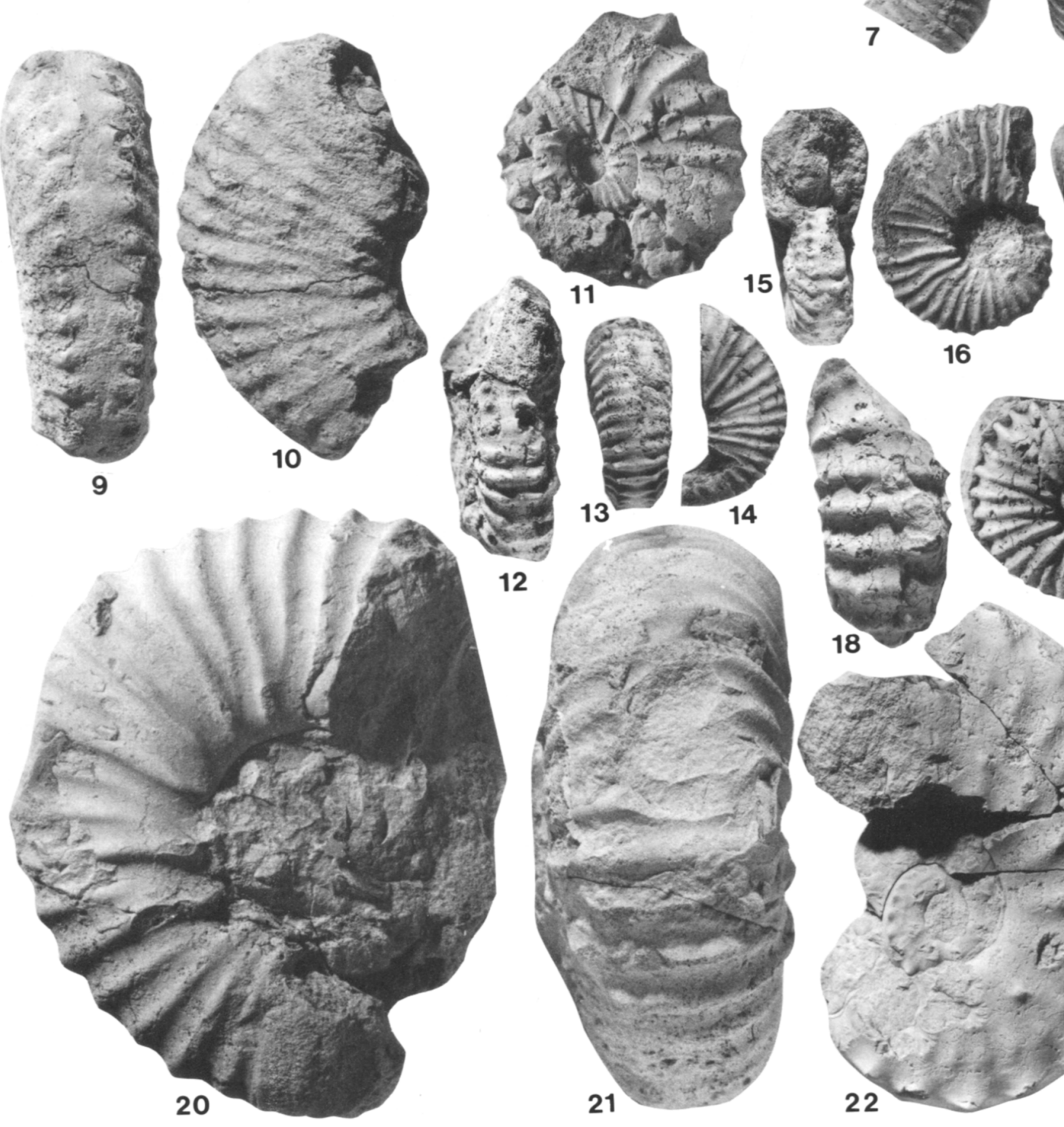

12
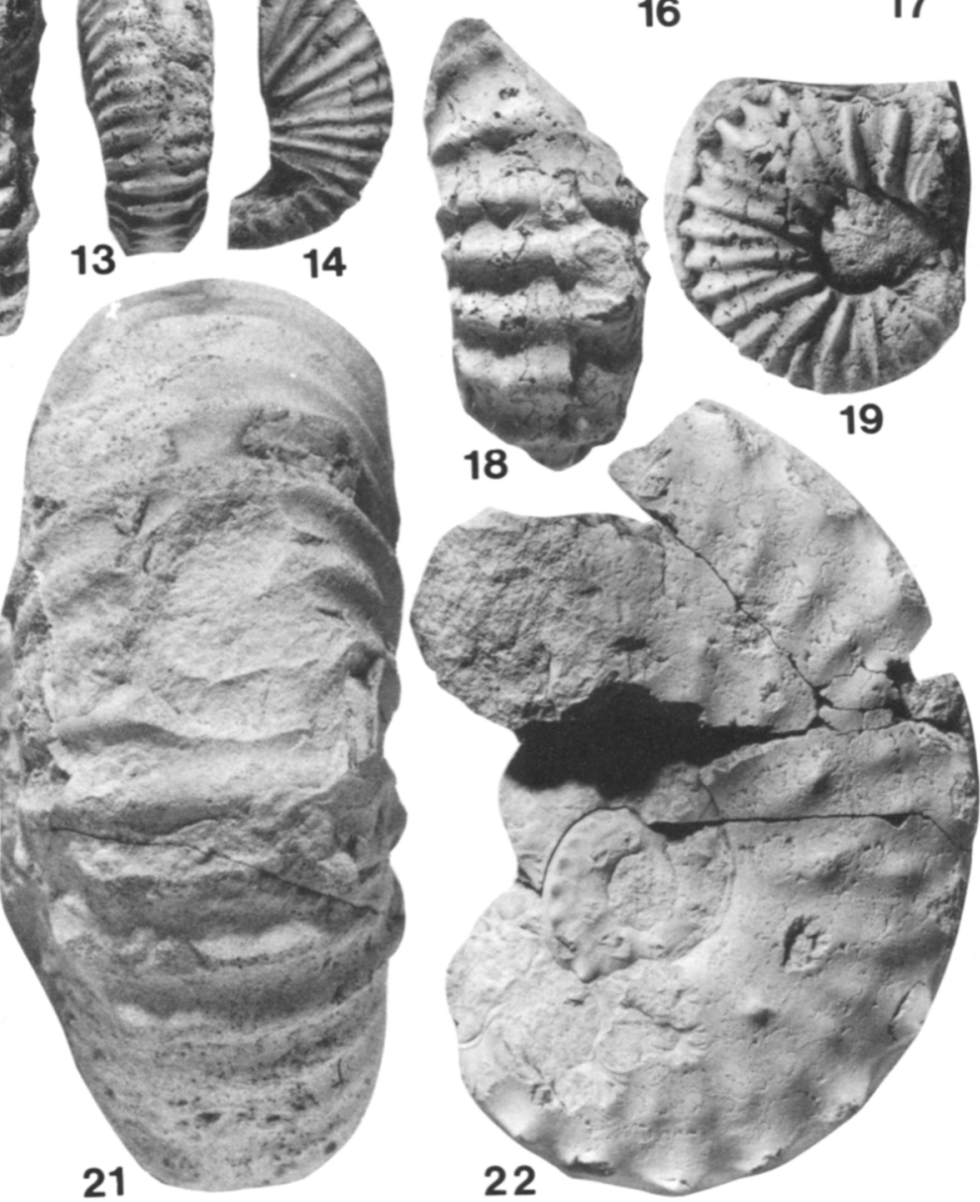
Discussion. - The synonymy lists only the most important specific and varietal names applied to Lower Cenomanian Schloenbachia, all of which are here regarded as synonyms of $S$. varians. As the figures show, there is every variation from depressed, hypernodose individuals corresponding to Stieler's ventriosa (Figure $8.7,8.8,8.18$ ) to ribbed and tuberculate specimens like the lectotype (Figure 8.10, 8.11), those in which the whorls are compressed and ribbing is more important, corresponding to Sharpe's subtuberculata (Figures 8.19, 8.20, 8.29, $8.30,9.22)$, to those in which ribbing is dominant and the shell compressed, corresponding to Pictet's tollotianus (Figure 8.9, 8.13-8.17). These are linked by passage forms, confirming the view that only a single species is present, as previously demonstrated by Juignet and Kennedy (1976), Marcinowski (1980), Hiss (1982), Kennedy and Juignet (1984), and others. For those who wish to use varietal names for Schloenbachia, it should be noted that the holotype of Pictet's Ammonites tollotianus represents the commonest form of this species (Figure 8.15, 8.16). It has feeble umbilical and inner lateral tubercles like individuals commonly referred to Schloenbachia subvarians Spath, 1926a, although it differs in detail from the missing holotype (Sharpe, 1853 , Pl. 8, fig. 7), which lacks such tubercles. Individuals corresponding to the very compressed, near-smooth variant (Schloenbachia subplana (Mantell, 1822) and intermedia (Mantell, 1822)) are poorly represented in our collection; the closest fragment is shown in Figure 8.23, 8.24.

Occurrence.-Lower Cenomanian of the Old World Boreal Realm from Greenland to Iran north of the Zagros and the Alpes-Maritimes in France. A single specimen is known from Aquitaine and the species is absent from the Iberian Peninsula.

Superfamily ACANTHOCERATACEAE de Grossouvre, 1894 Family FORBESICERATIDAE Wright, 1952

Discussion.-See Wright and Kennedy, 1984, p. 80.

Genus Forbesiceras Kossmat, 1897

(=Discoceras Kossmat, 1895; Cenomanites Haug, 1898; Neopulchellia Collignon, 1929)

Type species. - By the subsequent designation of Diener, 1925, p. 180: Ammonites largilliertianus d'Orbigny, 1841, p. 320, Pl. 95.

Discussion.-See Wright and Kennedy, 1984, p. 174.

FORBESICERAS LARGILLIERTIANUM (d'Orbigny, 1841) Figure 8.25

Ammonites largilliertianus D'ORBIGNY, 1841, p. 320, PI. 95.

Forbesiceras largilliertianum (d'Orbigny). KENNEDY AND JUIGNET, 1984, p. 143, figs. 22b-d, 25a-c, 26i, j, 27c, d, g, h, 28a-f; WRIGHT AND KenNeDy, 1984, p. 89, Pl. 11, figs. 2-6, Pl. 12, figs. 1-3, 9, Pl. 16, fig. 2, text-figs. 12A-L, 13A-S, 14A-H (with full synonymy); IMMEL AND SeYed-EMAmi, 1985, p. 97, Pl. 3, fig. 5.

Lectotype. - By the subsequent designation of Wright and Kennedy, 1984, p. 90; the fragment from the Rouen Fossil Bed, Côte Ste Catherine, Rouen, Seine-Maritime, France, in the d'Orbigny Collection (MNHP 6120a) refigured by Wright and Kennedy, 1984, text-fig. 12d, e.

Collection.-One specimen: MHNG 1270 from the Pointe de l'Ecorchoir, Haut-Giffre Massif, Haute-Savoie.

Discussion. - Our specimen is wholly septate and $70 \mathrm{~mm}$ in diameter. It shows the fine ribbing, compressed whorls, and narrow venter typical of this well-known species, closely resembling the better preserved Lower Cenomanian specimens figured by Wright and Kennedy (1984, Pl. 11, figs. 2-6).

This species is only likely to be confused with $F$. beaumontianum (d'Orbigny, 1841) (see below), from which it differs in its narrower venter and very compressed rather than evenly elliptical whorl section, as well as in details of ornament.

Occurrence. - This species ranges throughout the Lower and Middle Cenomanian. It occurs widely, if rarely, in western Europe, with records from Devon, Dorset, Somerset, Wiltshire, Hampshire, the Isle of Wight, Sussex, and Kent in England. It occurs widely in France from the Boulonnais to Sarthe and Provence, northern Spain, Cressier in Switzerland, the German Federal Republic, the U.S.S.R. east to the Carpathians, north Africa, Zululand, Madagascar, and southern India.

\section{FORBESICERAS BEAUMONTIANUM (d'Orbigny, 1841)} Figure $8.21,8.22$

Ammonites beaumontianus D'OrBignY, 1841, p. 328, Pl. 98, figs. 1, 2. Forbesiceras beaumontianum (d'Orbigny). KENNEDY AND JUIGNET, 1984, p. 147, figs. 26d-h, 27i; Wright AND KENNEDY, 1984, p. 91, Pl. 12, figs. 7, 8, Pl. 13, fig. 1, text-figs. 15A-C, 16A-F (with full synonymy).

Lectotype.-By the subsequent designation of Wright and Kennedy, 1984, p. 92; EMP 691, the original of d'Orbigny, 1841, Pl. 98, figs. 1, 2 from the Lower Cenomanian Craie Glauconieuse à Pecten asper of Lamnay, Sarthe.

Collection._One specimen: MHNG 1271 from Sautet, Platé Massif, Haute-Savoie.

Remarks. - Our specimen is a phosphatic fragment only, but the coiling, relatively evolute for the genus, the flat-sided whorls, and broad venter crossed transversely by narrow ribs, which bear outer ventrolateral tubercles, show this to be a $F$. beaumontianum rather than $F$. largilliertianum. The species is fully discussed by Wright and Kennedy $(1984$, p. 92).

Occurrence. - This species is restricted to the lower Neostlingoceras carcitanense Subzone of the Mantelliceras mantelli Zone of the Lower Cenomanian where precisely dated. It is rare in southern England (Sussex, Hampshire, Devon), France (Sarthe, Var), and Madagascar.

\section{FORBESICERAS CHEVILLEI (Pictet and Renevier, 1866)} Figure 9.1-3

Ammonites chevillei Pictet AND Renevier, 1866, p. 102, Pl. 4, fig. 2. Forbesiceras chevillei (Pictet and Renevier). WRIGHT AND KENNEDY, 1984 , p. 93, Pl. 13, fig. 2, PI. 15, figs. 1, 2, text-fig. 17 (with synonymy). Forbesiceras sculptum Crick, 1907. IMMEL AND SEYED-EMAMI, 1985, p. 97, Pl. 3, fig. 4.

Holotype.-By monotypy, the original of Pictet and Renevier, 1866, Pl. 4, fig. 2, from the "couche moyenne" at Cheville Valais, Switzerland, housed in the Musée géologique de Lausanne (MGL 3402).

Discussion. - The holotype is a worn phosphatic fragment only. Coiling is very involute, with a tiny umbilicus. The whorl section is highly compressed with broadly rounded flanks and a narrow, flattened venter; the whorl breadth to height ratio is approximately 0.45 . There are traces of fine prosiradiate ribs on the inner flank and small rounded tubercles at mid-flank. These give rise to groups of flat broad ribs that strengthen on the outer flank and terminate in long, low ventral clavi. These are linked over the venter by up to six fine transverse riblets with additional riblets in the interspaces.

Discussion. - Although only a fragment, the holotype shows well the distinctive ornament that links it to the extensive suite of English specimens described by Wright and Kennedy (1984). This has been a neglected species and no less than five other names have been given to it by other authors.

Occurrence. - Lower Cenomanian when precisely dated. The species is also known from Sussex, the Isle of Wright, and Devon in England, Nigeria, Madagascar, Spain, Zululand (South Africa), and Turkmenia (U.S.S.R.). 
Family ACANTHOcERATIDAE de Grossouvre, 1894

Subfamily MANTELliCERATINAE Hyatt, 1903 Genus MANTELlICERAS Hyatt, 1903

(=Couloniceras Busnardo, 1966; Promantelliceras Thomel, 1972; Neomantelliceras Thomel, 1972; Bunburyiceras Thomel, 1972)

Type species. - By original designation: Ammonites mantelli J. Sowerby, 1814, p. 119 (ICZN Specific Name No. 1634). Discussion.-See Wright and Kennedy, 1984, p. 200.

MANTElliceras MANTELli (J. Sowerby, 1814) Figure 9.4-9.6, 9.19, 9.21

Ammonites mantelli J. SOWERBY, 1814, p. 119, Pl. 55, lower figure only. Ammonites mantelli var. tuberculatus MANTELL, 1822, p. 114.

Mantelliceras indianense HYATT, 1903, p. 115.

Mantelliceras (Mantelliceras) laticostatum RENZ, 1963, p. 1107, Pl. 3, fig. 2.

Mantelliceras mantelli J. Sowerby. Collignon, 1964, p. 27, Pl. 323 , fig. 1436 , p. 66 , Pl. 337, figs. $1506-1508$, p. 68 , Pl. 338, figs. 1509 , 1510 (var. percostata).

Mantelliceras tuberculatum Mantell. Collignon, 1964, p. 27, Pl. 323 , fig. 1437, p. 68, Pl. 338, fig. 1511 (var. umbilicata), p. 512, Pl. 339, figs. 1513-1517 (var. pinguis).

Mantelliceras ampakabense Collignon, 1964, p. 74, Pl. 341, fig. 1528.

Mantelliceras isovokyense Collignon, 1964, p. 76, Pl. 342, figs. 1529 , 1530.

Mantelliceras betiokyense Collignon, 1964, p. 78, Pl. 343, figs. 1531, 1532.

Mantelliceras alternans Collignon, 1964, p. 97, Pl. 351, fig. 1557.

Mantelliceras (Neomantelliceras) zeilleri THOMEL, 1972, p. 44, Pl. 13, figs. $1-4$.

Mantelliceras mantelli (J. Sowerby). SzÁsz, 1983, p. 243, Pl. 5, fig. 3, Pl. 6, figs. 2, 3, Pl. 12, figs. 1, 2, Pl. 19, fig. 5; WRIGHT AND KENNEDY, 1984 , p. 99 , Pl. 16, fig. 5, Pl. 17, figs. 1, 3, Pl. 18, figs. 1-3, Pl. 19, figs. 1-6, Pl. 21, figs. 2, 4, Pl. 24, fig. 3, Pl. 36, fig. 1, text-figs. 20AD, 26A, C, E (with full synonymy); IMMEL AND SEYED-EMAMI, 1985, p. 99, Pl. 4, fig. 5; KENNEDY, JUIGNET, AND WRIGHT, 1986, p. 22, figs. 2a, 4a-g, 10d, e, 23a, b, f.

Mantelliceras tuberculatum (Mantell). IMMEL AND SEYED-EMAMI, 1985, p. 99, Pl. 4, fig. 4.

Lectotype.-By the subsequent designation of Kennedy, 1971 , p. 52: BMNH 43940a from the Lower Cenomanian Chalk Marl of Ringmer Near Lewes, Sussex (=J. Sowerby, 1814, Pl. 55, lower figure only).

Collections. - Five specimens: MHNG 19378 and MGL 42990 from Cheville, Morcles Massif, Valais; MHNG 1240 from Arberroz and MHNG 1227 from Lindars, both in the Plate Massif, Haute-Savoie; MHNG 19379 from Bourgets (Mont Saxonnet of authors), Bornes Massif, Haute-Savoie.

Discussion. - The synonymy gives only the most important forms regarded as synonyms of this species; see Wright and Kennedy, 1984, p. 99 for additional details. Juveniles of $M$. mantelli are characterized by a polygonal whorl section with 32-40 ribs per whorl, alternating irregularly long and short. The long ribs have umbilical and lateral tubercles and inner and outer ventrolateral clavi. The short ribs all bear inner and outer ventrolaterals while a few of the longer ones have the lateral tubercle as well. Microconchs of the species are adult at $60 \mathrm{~mm}$; macroconchs (Figure 9.20,9.21) are known to be up to $150 \mathrm{~mm}$ in diameter. Lateral and inner ventrolateral tubercules disappear on the adult body chamber, while the outer ventrolaterals decline or disappear to give a rounding venter.

Wright and Kennedy (1984, p. 99) outlined the reasons for regarding the species and varieties listed in the synonymy as inseparable from $M$. mantelli. The species is easily distinguished from $M$. lymense (Spath, 1926b), M. couloni (d'Orbigny, 1850), and $M$. saxbii (Sharpe, 1857), which are generally compressed and typically lack lateral tubercles. Mantelliceras picteti Hyatt,
1903, has a similar style of ribbing and tuberculation but the whorl section is quadrate and compressed, with rather distant ribbing at maturity. Mantelliceras cantianum Spath, 1926a, is very inflated with a whorl section that expands rapidly during development, has a broad venter with strong ribs and feeble outer ventrolateral tubercles, inner ventrolateral tubercles that are lost early in ontogeny, and strong lateral tubercles linked to a weak umbilical bulla by a strong rib.

Occurrence. - Elsewhere in Europe the species is commonest in the lower two-thirds of the Lower Cenomanian and is only rarely found above. It ranges from England to northern Ireland (a doubtful record), the Boulonnais, Haute Normandie, Sarthe, Maine, the Argonne, Iserè and south to Cassis (Bouches-duRhône) in France and the remainder of western Europe, the U.S.S.R., north Africa, Madagascar, and southern India.

\section{MANTElliCERAS CANTIANUM Spath, 1926a \\ Figures $10.1-10.5,10.10-10.12,11.7-11.8$ $12.1-12.4$}

Mantelliceras cantianum SPATH, 1926a, p. 82.

Calycoceras souaillonense RENZ, 1963, p. 1111, Pl. 6, fig. 1.

Mantelliceras cantianum Spath. Collignon, 1964, p. 80, Pl. 344, fig.

1532, ?fig. 1533 (var. unituberculata), non fig. 1534 (var. abrupta).

Mantelliceras geyeri Collignon, 1964, p. 99, Pl. 352, fig. 1560.

Mantelliceras (Bunburyiceras) moulinense THOMEL, 1972, p. 47, PI. 14, figs. 3-5.

Mantelliceras cantianum Spath. SzÁsz, 1983, p. 244, Pl. 5, fig. 4, Pl. 6 , figs. 4, 5, Pl. 13, figs. 2-4, Pl. 16, fig. 2, Pl. 17, fig. 2; WRIGHT AND KENNEDY, 1984, p. 103, Pl. 17, fig. 2, Pl. 20, fig. 3, Pl. 21, fig. 3, Pl. 24, figs. 1, 2, 4-6, Pl. 25, figs. 1-6, Pl. 26, figs. 1, 2, 4, 5, text-figs. 25A, 27E-H, J-L; Kaplan, Keller, and WiedmanN, 1984, Pl. 3, fig. 4; IMMEl AND SeYed-EMami, 1985, p. 100, Pl. 4, fig. 4; KenNedy, JUIGNET, AND WRIGHT, 1986, p. 31, Figs. $2 \mathrm{~b}-\mathrm{e}, 6 \mathrm{a}-\mathrm{c}, 7,8 \mathrm{a}-\mathrm{c}, 16 \mathrm{i}$, j, $18 \mathrm{a}-\mathrm{e}, 20 \mathrm{e}, \mathrm{f}$.

Holotype. - By original designation, BMNH 36834, from the Lower Cenomanian Chalk Marl of Dover, Kent, paratype BMNH C5027 is from the same unit at Lewes, Sussex. They were figured by Sharpe, 1857 (Pl. 18, figs. 1, 2).

Collections.-Nine specimens MGL 8371, MHNG 19411, 1223, 1228 from Cheville and MHNG 19374 from Ecuelle, Morcles Massif, Valais; MHNG 19376 from the Lanche des Aux, Haute-Giffre Massif, Valais; MHNG 1220, 1226, 1337, from Lindars, Platé Massif, Haute-Savoie.

Discussion. - The early whorls of this species are generally inflated and expand rapidly. The ribs are coarse, 28-36 per whorl, alternately long and short. The long ribs bear a strong umbilical bulla and even stronger inner lateral tubercle, linked by a strong rib (Figures $10.12,12.1-12.4$ ) that persists to the beginning of the adult body chamber (Figure 10.11, 10.12).

Both long and short ribs bear inner ventrolateral tubercles that decline and disappear in middle growth and outer ventrolateral tubercles that persist to the beginning of the adult body chamber (Figure 10.10-10.12).

The present collection includes a fine adult macroconch 100 $\mathrm{mm}$ in diameter and complete microconchs $62-66 \mathrm{~mm}$ in diameter; elsewhere macroconchs are up to $150 \mathrm{~mm}$ in diameter, with microconchs $60-80 \mathrm{~mm}$ in diameter. One specimen has a more slowly expanding whorl section and serpenticone form, a type found in both England and northern France (Wright and Kennedy, 1984, Pl. 20, fig. 3).

Of other species recognized in the present study, only Mantelliceras mantelli is likely to be confused with $M$. cantianum, but the massive, depressed, rapidly expanding whorls with prominent umbilico-lateral tuberculation of the latter are distinctive.

Occurrence. - The species ranges throughout the Lower Cen- 
omanian in western Europe, although it is rare in the upper third of the substage. In England it is widespread from Norfolk south and southwestwards, also occurring in northern Ireland. It also occurs in the Boulonnais, Haute Normandie, Sarthe, Maine, the Argonne, Isère south to Cassis (Bouches-du-Rhône) in France, in Switzerland, in Lleida in Spain, Roumania, Iran, Madagascar, and Japan.

MANTELliCERAS PICTETI Hyatt, 1903

Figure $12.5,12.6,12.9,12.10,12.13,12.14$

Mantelliceras picteti HYATT, 1903, p. 114, pars MARCINOWSKI AND RADWANSKY, 1983, PI. 7, fig. 10; KENNEDY, JUIGNET, AND WRIGHT, 1986, p. 35, text-figs. 8d, e, 9, 10a-c, 11a-d.

Mantelliceras tenue SPATH, 1926b, p. 427, 430.

Mantelliceras cressierense RENZ, 1963, p. 1105, Pl. 4, fig. 3.

Mantelliceras antanimangaense CollignON, 1964, p. 83, Pl. 346, fig. 1539.

Mantelliceras patens Collignon, 1964, p. 87, Pl. 347, fig. 1546.

Mantelliceras crassecostatum ColligNoN, 1964, p. 95, Pl. 350, figs. 1553, 1555, ?1554.

Mantelliceras (Submantelliceras) marrei THOMEL, 1972, p. 23, PI. 8, figs. 1-6.

Mantelliceras (Couloniceras) couloni ravelense THомеL, 1972, p. 30, Pl. 3, figs. 1-3.

Mantelliceras (Promantelliceras) picteti collignoni TномеL, 1972, p. 33, Pl. 5, figs. 3-5, Pl. 6, fig. 3.

Mantelliceras (Promantelliceras) picteti alpina forma crassa THOMEL, 1972, p. 34.

Mantelliceras (Promantelliceras) picteti densecostata THомеL, 1972, p. 35, Pl. 5, figs. 1, 2.

Mantelliceras picteti Hyatt. SzÁsz, 1983, p. 247, Pl. 13, fig. 5, Pl. 16, fig. 2; Wright AND KENNEDY, 1984, p. 117, Pl. 27, figs. 1-5, Pl. 28, figs. 1-3, text-figs. $25 \mathrm{~g}, 27 \mathrm{n}-\mathrm{q}$ (with full synonymy).

Mantelliceras tenue Spath, 1926. IMMEL AND SEYED-EMAMI, 1985, p. 100, Pl. 4, fig. 7.

Lectotype. - By subsequent designation of Wright and Kennedy, 1984, p. 117, the original of Pictet and Campiche, 1859, Pl. 26, fig. 3, from the Cenomanian of St. Croix, Switzerland. This is also the holotype, by original designation, of Mantelliceras tenue Spath, 1926b, which is thus an objective synonym.

Collections. - Three specimens: MHNG 1218, 1224 from the Lanche des Aux, Haut-Giffre Massif, Valais, and MG L42865 from Ecuelle, Morcles Massif, Valais.

Discussion. - This species shows moderately evolute coiling, with compressed, subrectangular whorls. The ribs are alternately long and short, and number 34-38 per whorl. The long ribs bear umbilical, lateral, inner and outer ventrolateral tubercles; the short ribs bear inner and outer ventrolaterals only.

Compressed whorls separate this species from $M$. mantelli and $M$. cantianum, while the ornament of the latter is highly distinctive. Mantelliceras couloni (d'Orbigny, 1850) and M. saxbii (Sharpe, 1857) are also compressed. The former lacks a lateral tubercle and bears high ventral clavi during much of its ontogeny. The latter sometimes bear a feeble or incipient lateral tubercle, but this does not persist as it does in $M$. picteti. The inner whorls of some variants of $M$. dixoni Spath, 1926b, resemble those of $M$. picteti, but tubercles decline more rapidly in the former, and the bar-like strengthening of the primary ribs on the inner flank is distinctive in juveniles, as is loss of ornament on adult body chambers.

Occurrence. - In southern England the species is widespread and restricted to the lower two-thirds of the Lower Cenomanian. It also occurs in the Boulonnais, Haute Normandie, the Argonne and Isère south to the Alpes-Maritimes in France, in northern Spain, Switzerland, Podolia, the Crimea, Iran, and Madagascar.

MANTELliCERAS COULONI (d'Orbigny, 1850)

Figures 9.7, 9.8, 9.11-9.18, 10.6-10.9, 13.1, 13.2

Turrilites ?babeli Brongniant, 1822, p. 99, 400, Pl. 9, fig. 16.

Ammonites Mantelli Sowerby. D'OrBIGNY, 1841, p. 340 (pars), Pl. 104, figs. $1-4$.

Ammonites couloni D'OrBiGNY, 1850, p. 147.

?Mantelliceras couloni (d'Orbigny). SzÁsz, 1983, p. 246, Pl. 17, fig. 3.

?Mantelliceras aff. couloni (d'Orbigny). SzÁsz, 1983, p. 247, Pl. 17,

fig. 1.

Mantelliceras couloni (d'Orbigny, 1850). WRIGHT AND KENNEDY, 1984, p. 119, Pl. 21, fig. 1, Pl. 23, figs. 5, 6, Pl. 29, figs. 1-3, Pl. 30, figs. 1, 2, Pl. 31, figs. 3-5, PI. 36, fig. 5, text-figs. $25 \mathrm{~F}, \mathrm{H}, 27 \mathrm{~A}-\mathrm{D}$ (with full synonymy); KENNEDY, JUIGNET, AND WRIGHT, 1986, p. 41, figs. 1a $2 \mathrm{f}, 12,13,14 \mathrm{a}, \mathrm{d}-\mathrm{f}, 15 \mathrm{a}-\mathrm{c}$.

Lectotype.-By the subsequent designation of Juignet and Kennedy, 1976, p. 95, is MNHP 1896-27 (ex de Vibraye Collection), the original of d'Orbigny, 1841, Pl. 104, figs. 1, 2, from the Lower Cenomanian Craie Glauconieuse à Pecten asper of Lamnay, Sarthe, France. Paralectotypes MNHP 6116 (d'Orbigny Collection) are from Lamnay and were the basis of d'Orbigny's Pl. 104, figs. 3, 4. A further paralectotype, MNHP 6116a (d'Orbigny Collection) is from "Vibrayes."

Collections. - Ten specimens: MHNG 19375, 1253, 1300, 1322 and EMP unregistered, the holotype of Turrilites? babeli Brongniart, 1822 (original of Pl. 9, fig. 16), from the Rochers des Fiz. MHNG 1237-1239 from Arberroz, MHNG 1286 from Lindars, MHNG 1289 from Sautet, all in the Plate Massif, Haute-Savoie. Also MHNG 1221 from Bourgets (=Mont Saxonnet of authors), Bornes Massif, Haute-Savoie.

Discussion. - The early whorls of this species are densely and flexuously ribbed, the ribs arising singly or in pairs from small umbilical bullae with some shorter intercalated ribs to give a total of up to 40 ribs per whorl. There are inner and outer ventrolateral tubercles during early growth (Figure 9.11, 9.12, 9.15-9.18); the former decline during middle growth in most specimens, but the latter strengthen into high clavi (Figure 10.710.9) that persist onto the early part of the adult body chamber. These clavi decline towards the adult aperture, where the venter broadens and rounds and the ribs crowd (Figure 13).

Absence of lateral tubercles separates this species from $M$. mantelli, $M$. picteti, and $M$. cantianum. Mantelliceras lymense have inflated whorls and never develop the distinctive clavi of $M$. couloni. There are close similarities to $M$. saxbii (see below)

FIGURE 10-1-5, 10-12, Mantelliceras cantianum Spath, 1926a. 1, 2, MHNG 19376; 3-5, MHNG 1226; 10-12, MHNG 19411. 6-9, Mantelliceras couloni (d'Orbigny, 1850). 6, MHNG 1286; 7-9, EMP unregistered, the holotype of Turrilites babeli Brongniart, 1822, Pl. 9, fig. 16. All figures are natural size.

FIGURE 11-1-4, Mantelliceras dixoni Spath, 1926b. 1, 2, MGL 42847; 3, 4, MHNG 1217. 5, 6, 9-13, Mantelliceras saxbii (Sharpe, 1857). 5, 6, MHNG 19377; 9, 10, MHNG 1236; 11-13, MHNG 1274. 7, 8, Mantelliceras cantianum Spath, 1926a, MHNG 19374. All figures are natural size.

FIGURE 12-1-4, Mantelliceras cantianum Spath, 1926a. 1, 2, MHNG 1223; 3, 4, MHNG 1228. 5, 6, 9, 10, 13, 14, Mantelliceras picteti Hyatt, 1903. 5, 6, MHNG 1218; 9, 10, MHNG 1225; 13, 14, MHNG 1224. 7, 8, Mantelliceras lymense (Spath, 1926b), MGL 42992. 11, 12, Mantelliceras dixoni Spath, 1926b, MGL 42853. All figures are natural size. 

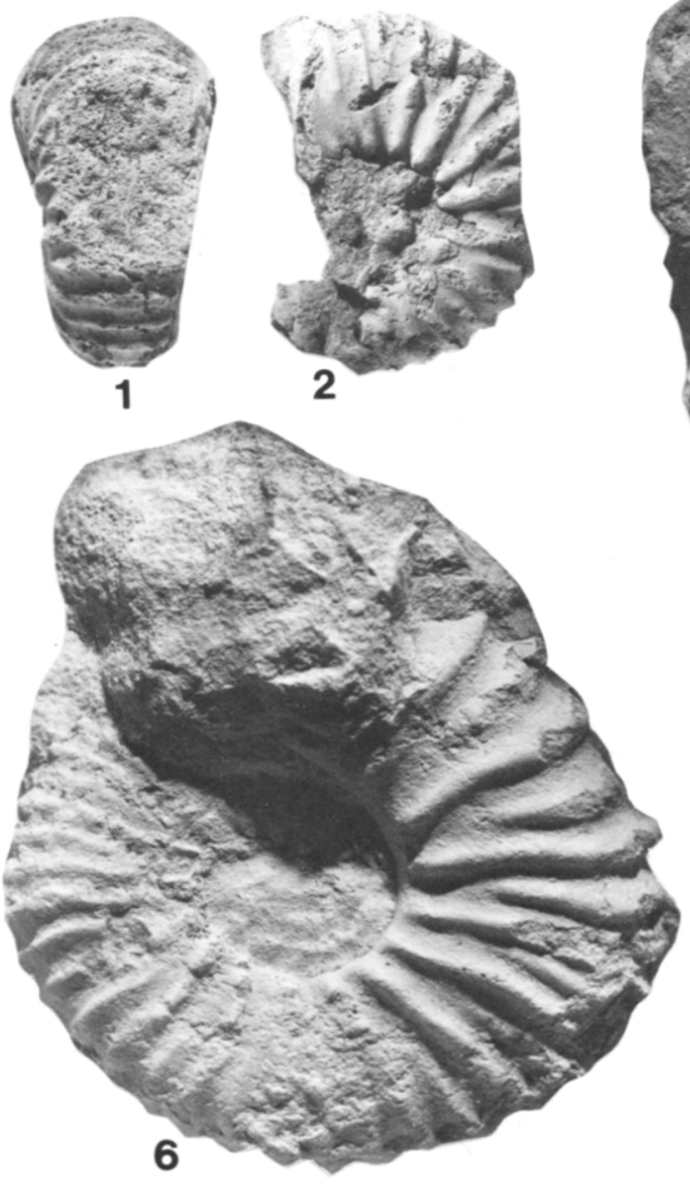

6.

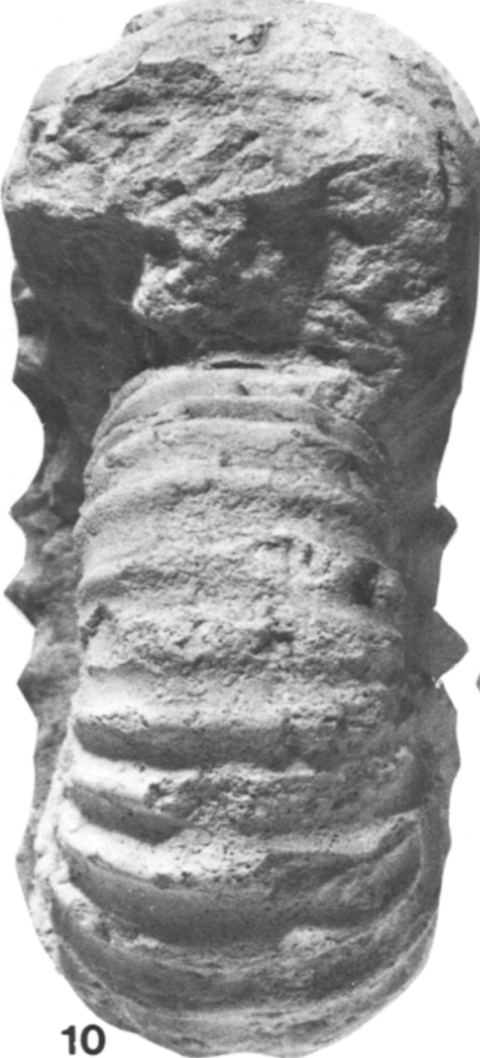

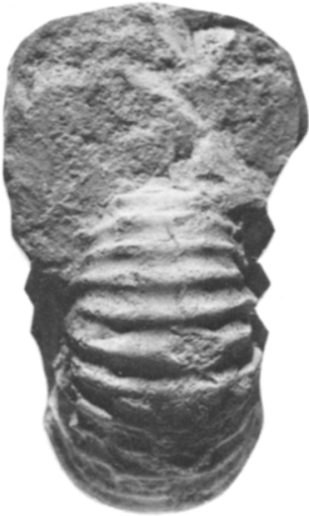

3

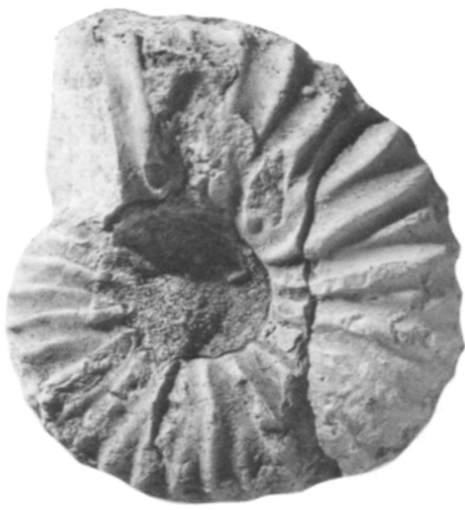

4
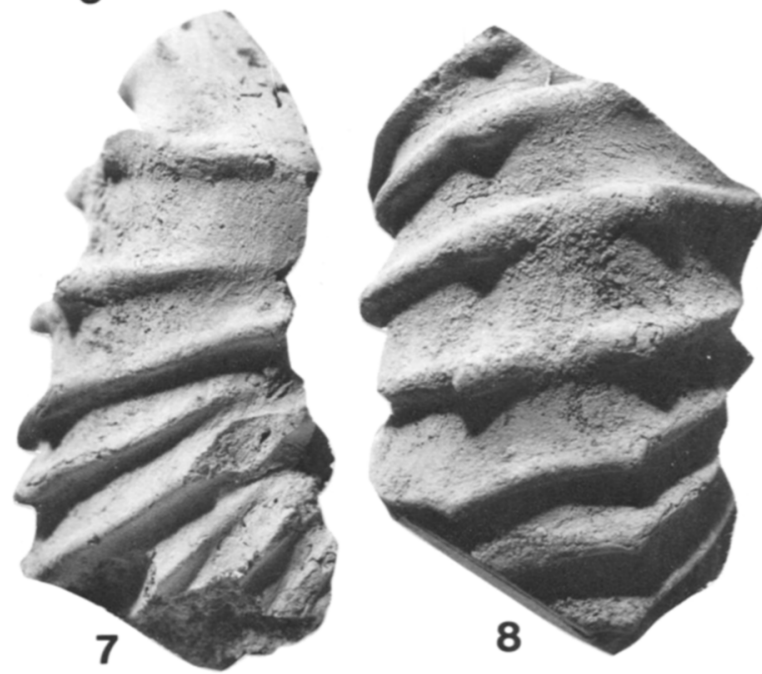

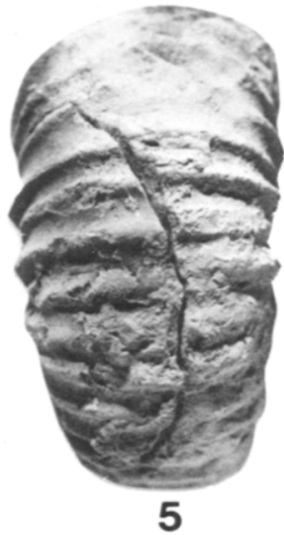

5
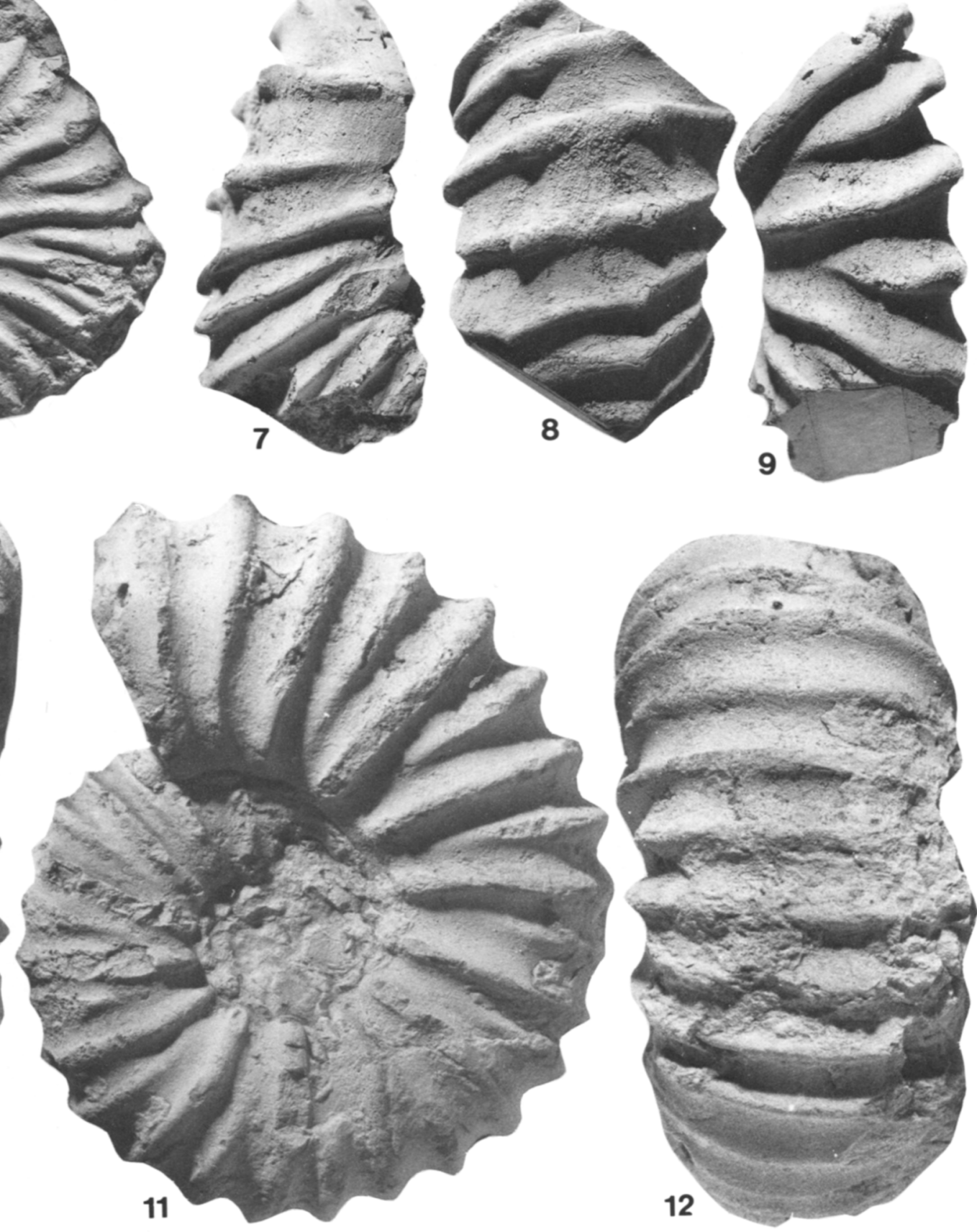


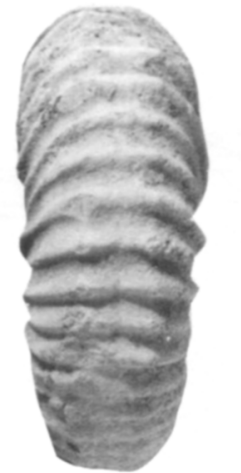

1
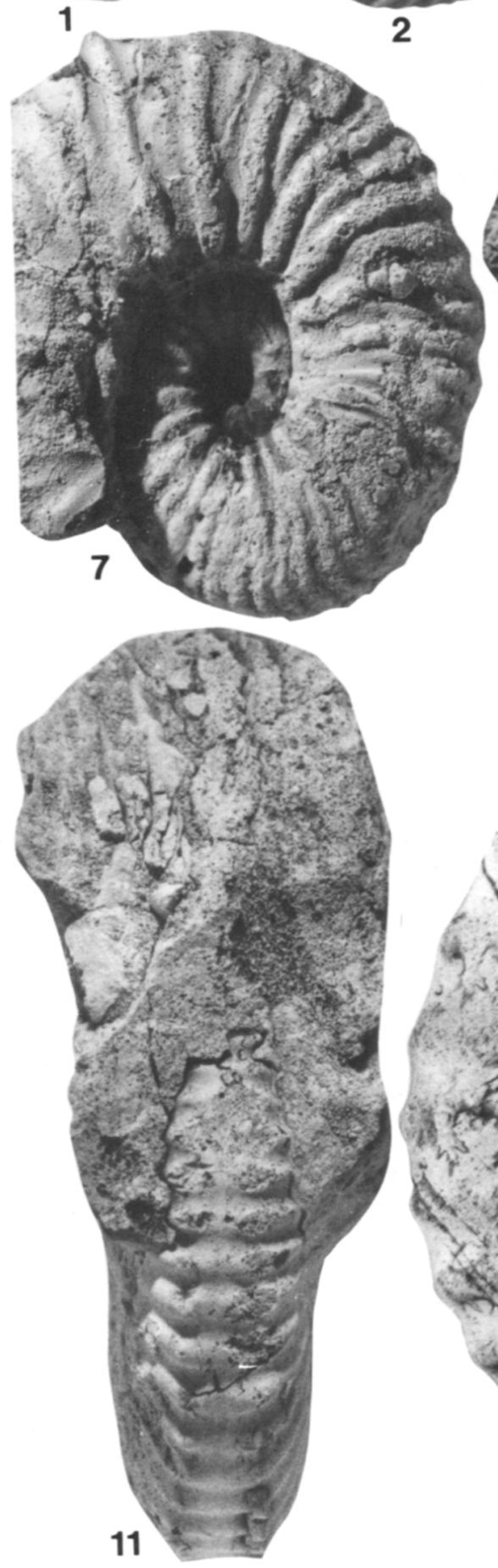
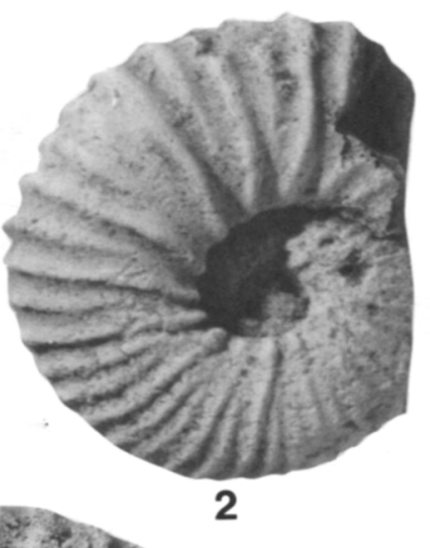
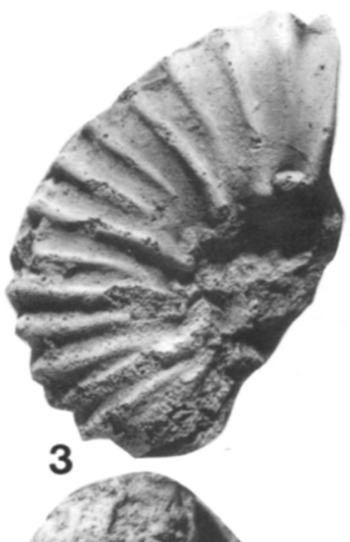
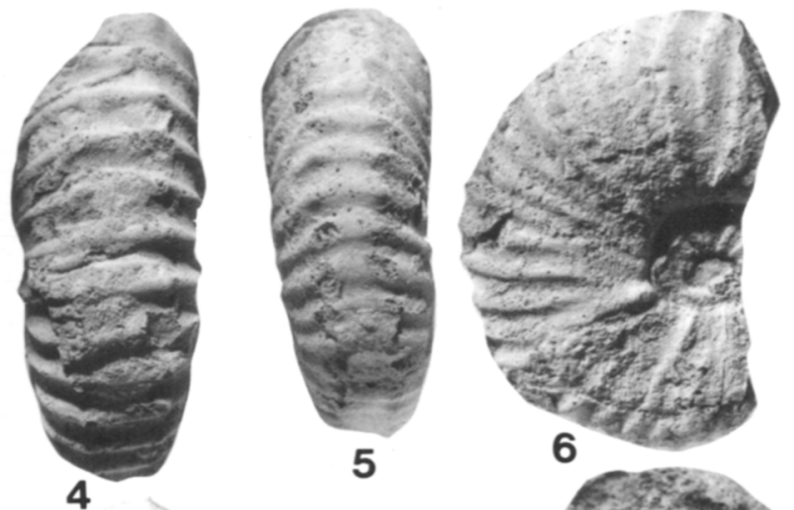

5
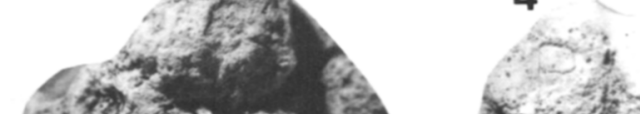

.

(t) * mor nas
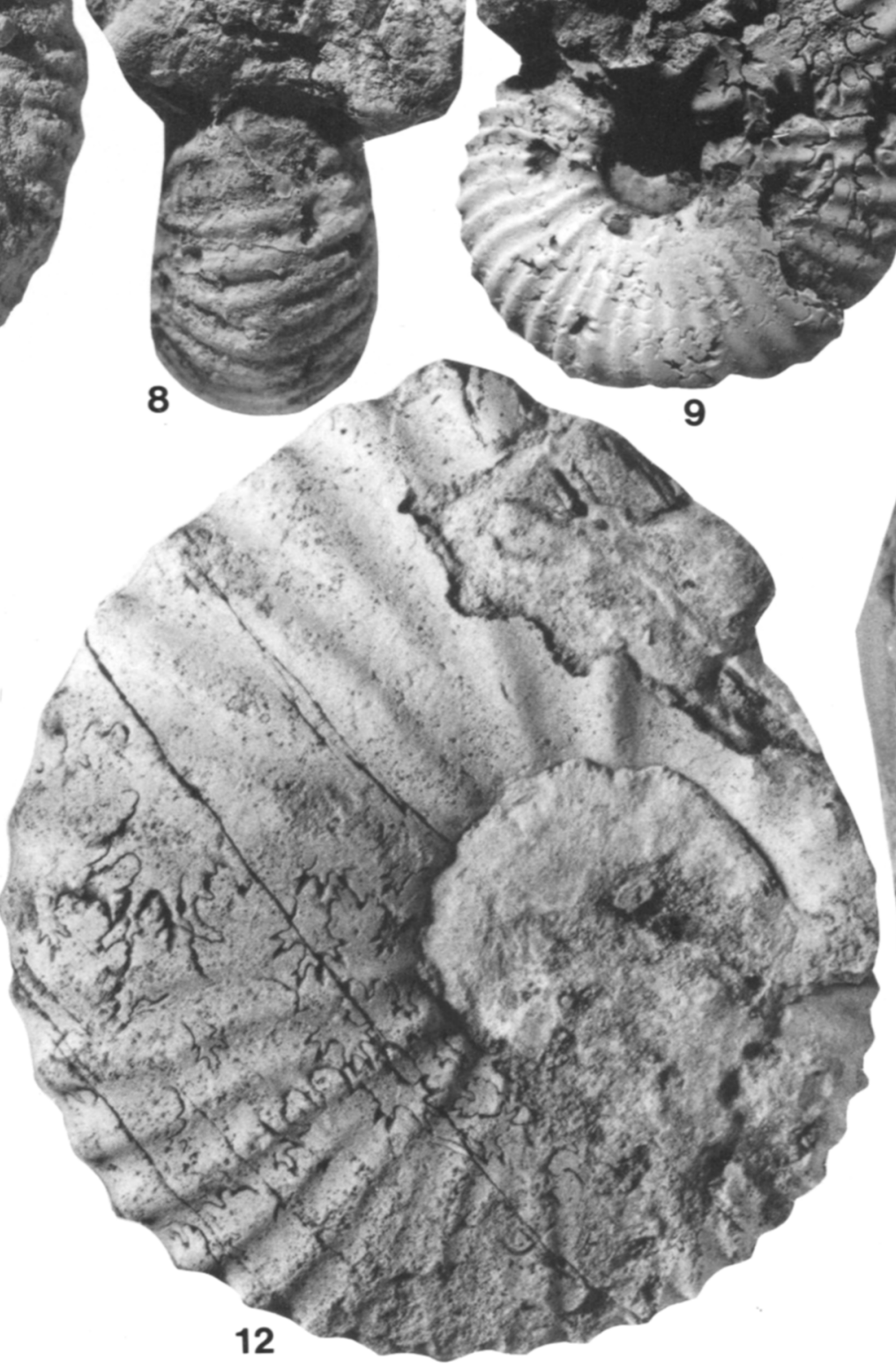
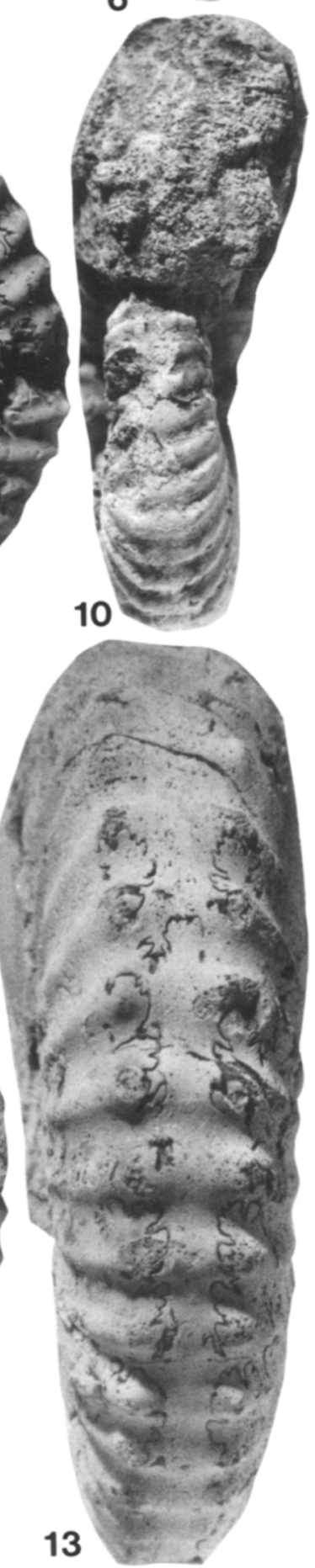


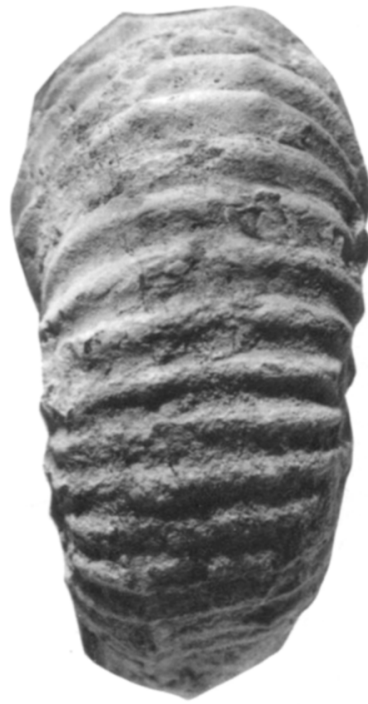

1

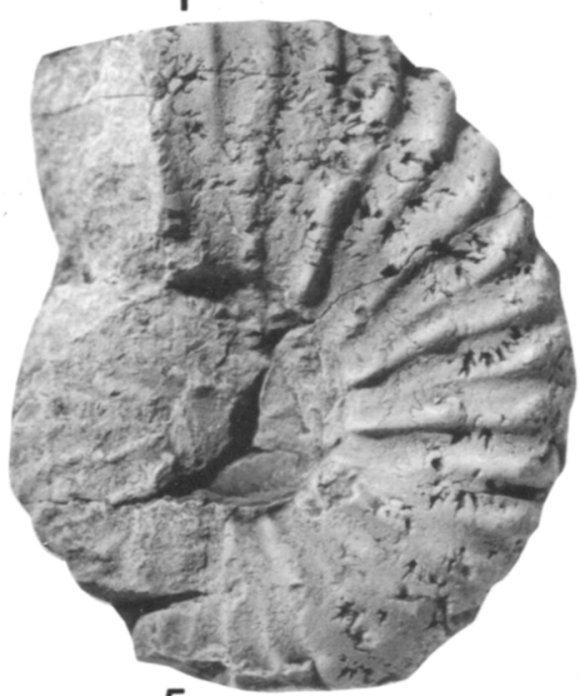

5

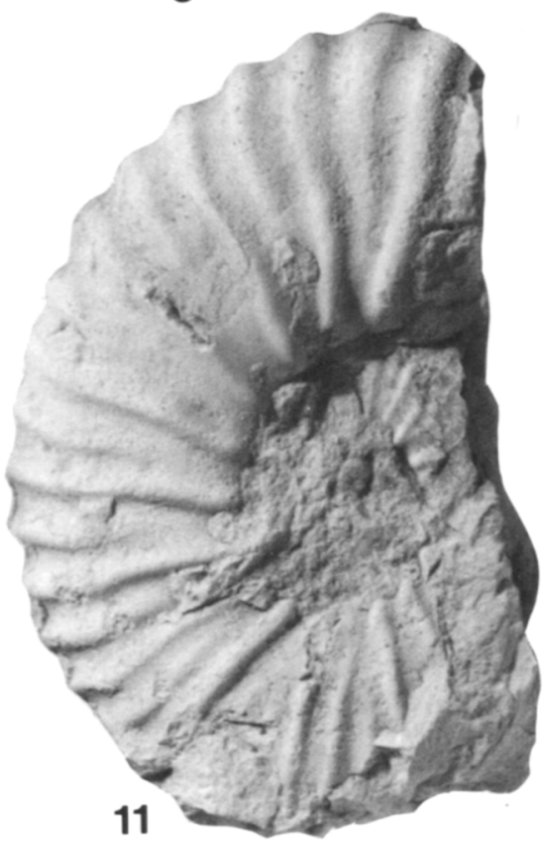

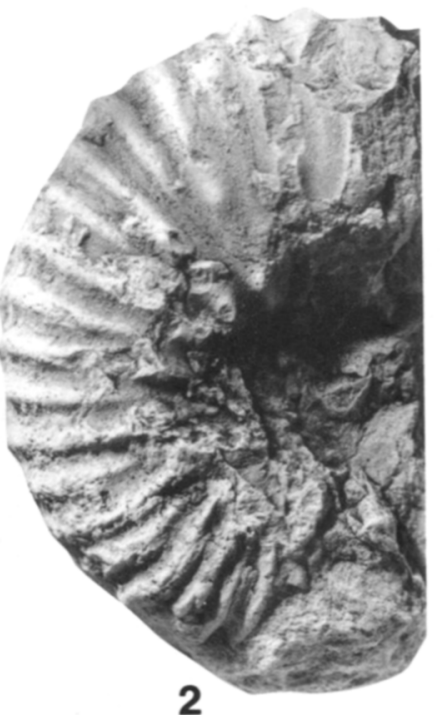
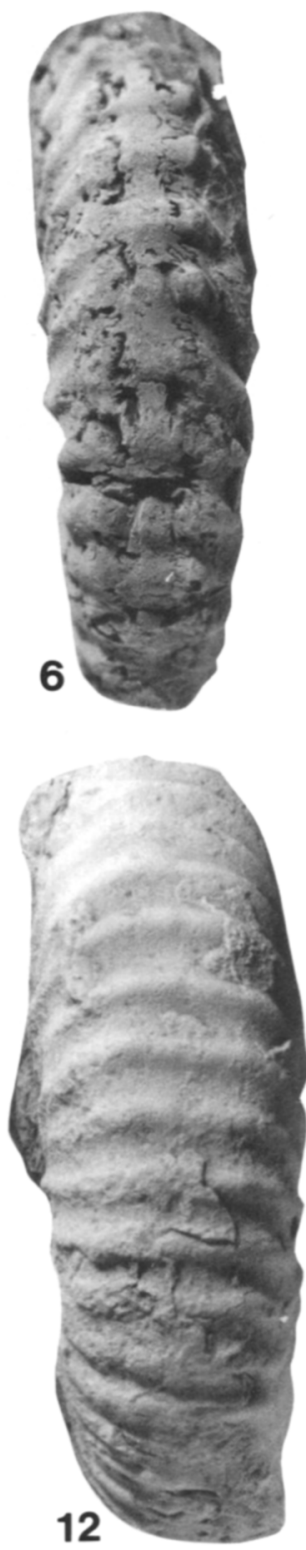
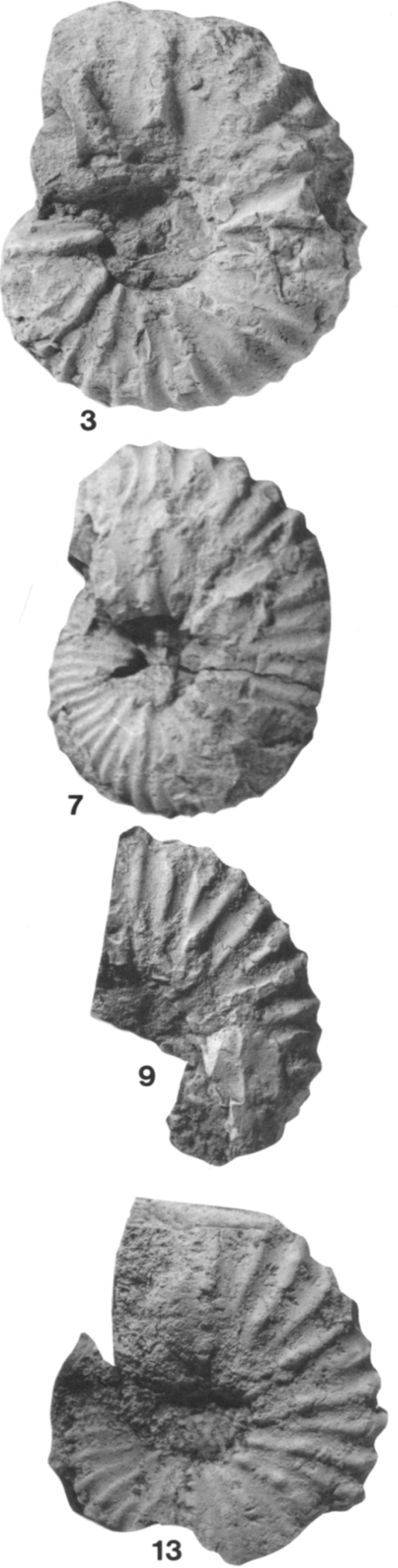
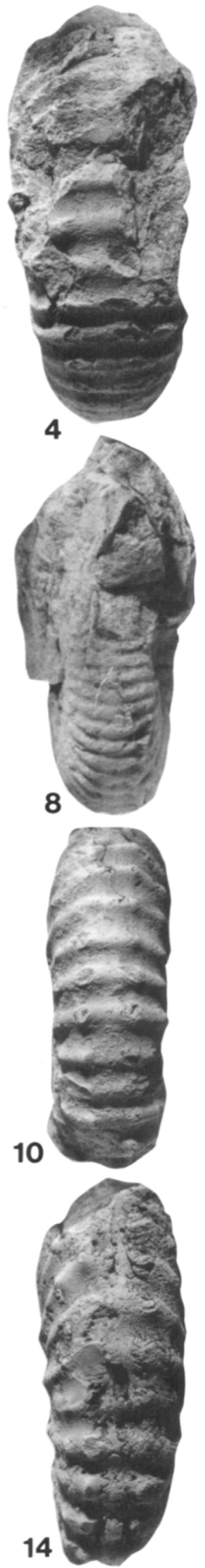

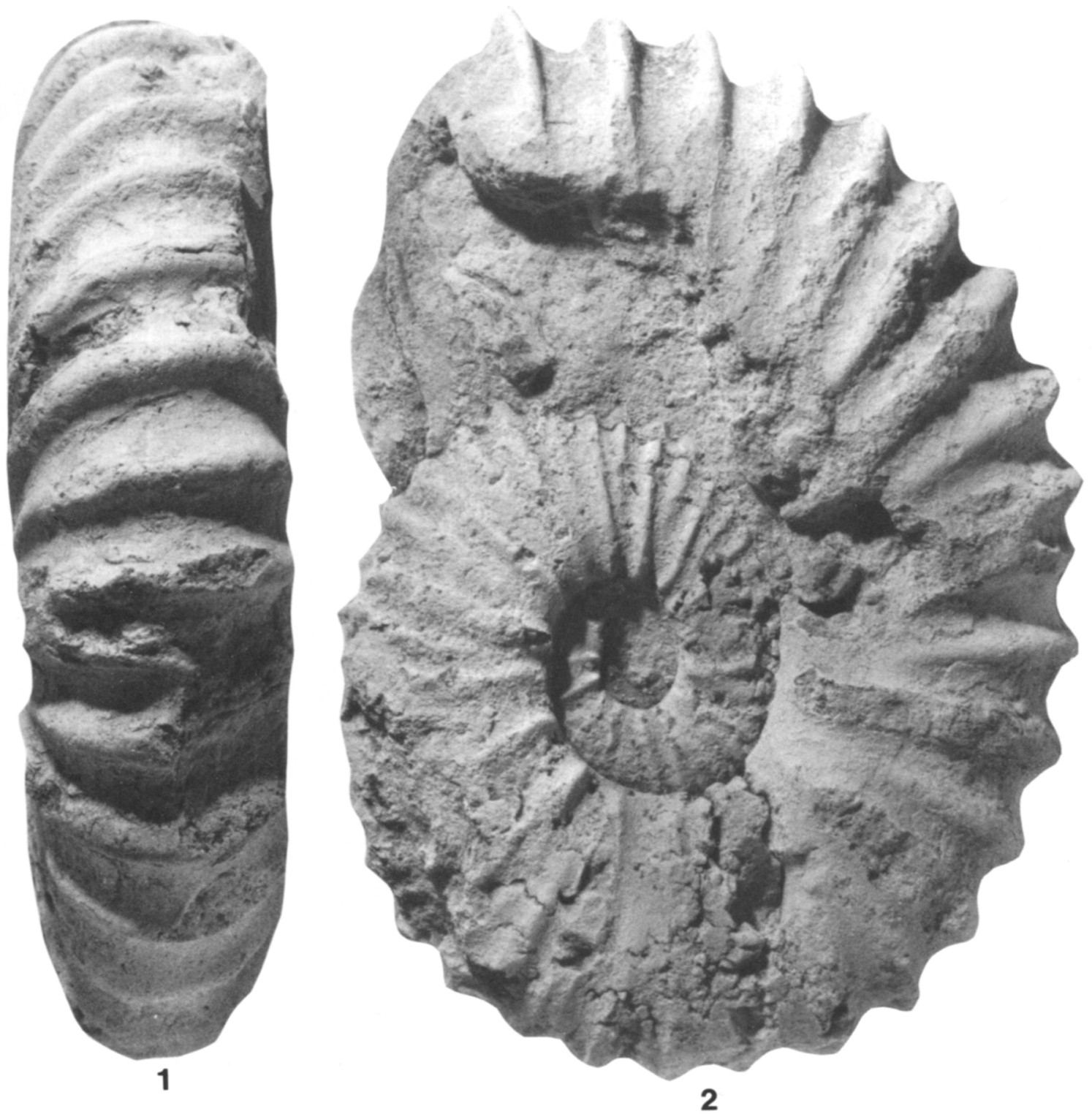

Figure 13-1, 2, Mantelliceras couloni (d'Orbigny, 1850). MHNG 1221, from Bourgets (=“Mont Saxonnet" of authors), Bornes Massif, HauteSavoie. All figures are natural size.

which is also a compressed species, but it never develops the exaggerated clavi of the present form. Turrilites? babeli Brongniart, 1822 (p. 99, 400, Pl. 9, fig. 16) is based on a poor fragment from the Rochers de Fiz, reillustrated here as Figure 10.7-10.9 that may be a fragment of $M$. couloni.

Occurrence. - This species has a very restricted stratigraphic range at the top of the Lower Cenomanian $N$. carcitanense Subzone of the $M$. mantelli Zone. At the type locality and elsewhere in Sarthe there are records from the Gaize facies in the lower part of the Craie Glauconieuse à Pecten asper. In England it occurs chiefly in Dorset and Devon with a single occurrence in the Isle of Wight, Hampshire. It also occurs in the Lower Cenomanian of southeastern France, Iran, and perhaps Roumania.

MANTElliceras SAXBII (Sharpe, 1857)

Figure 11.5-11.6, 11.9-11.13;14.1-14.4

Ammonites saxbii SHARPE, 1857, p. 45, Pl. 20, fig. 3.

Ammonites martimpreyi CoQUAND, 1862, p. 172, Pl. 1, figs. 7, 8.
Mantelliceras ventnorense DIENER, 1925, p. 170.

Mantelliceras subcostatum SPATH, 1925, p. 197.

Mantelliceras batheri SPATH, 1926b, p. 431, pars.

Calycoceras planum RENZ, 1963, p. 1111, Pl. 5, fig. 2.

Mantelliceras hyattiforme Collignon, 1964, p. 71, PI. 340, figs. 15211524.

Mantelliceras biroi Collignon, 1964, p. 84, Pl. 346, figs. 1540, 1541, Pl. 351, fig. 1540.

Mantelliceras agrawali Collignon, 1964, p. 86, Pl. 347, figs. 1542 , 1543.

Mantelliceras agrawali var. concava Collignon, 1964, p. 86, Pl. 347 , fig. 1544.

Mantelliceras agrawali var. celsa Collignon, 1964, p. 87, Pl. 347, fig. 1545.

Mantelliceras spissum Collignon, 1964, p. 90, Pl. 348, figs. 1549, 1550. Mantelliceras divaricatum Collignon, 1964, p. 97, Pl. 351, fig. 1556.

Mantelliceras (Couloniceras) roqueti BUSNARDO, 1966, p. 224, PI. 12, fig. 5, Pl. 14, fig. 1 .

?non Mantelliceras saxbii paucicostatum THOMEL, 1972, p. 20, Pl. 1, fig. 7 . 
Mantelliceras (Couloniceras) couloni tourrettense THомеL, 1972, p. 29, Pl. 3, figs. 4-9.

Mantelliceras saxbii (Sharpe). SzÁsz, 1983, p. 245, Pl. 6, fig. 6, ?Pl. 7, figs. 3, 4, ?Pl. 9, fig. 1, ?Pl. 10, fig. 1, ?Pl. 18, fig. 4; KAPLAN, Keller, AND WIEDMANN, 1984, Pl. 3, fig. 3; KENNEDY, JUIGNET, AND WRIGHT, 1986, p. 43, figs. 1c, 2d, 9, 11 e, 14b, c, 16a-d, g-h, k-1, 17a-d, 19ac; WRIGHT AND KENNEDY, 1984, p. 121, Pl. 23, fig. 4, Pl. 23, figs. 13 , Pl. 33, figs. $1-4$, Pl. 34, figs. $1-4$, Pl. 35, figs. $1-5$, Pl. 36, figs. 2,3 , Pl. 39, fig. 1, text-figs. 25B-D, I, 26B, 28 L-P (with full synonymy); non IMMEL AND SEYED-EMAMI, 1985, p. 102, Pl. 6, fig. 5.

Submantelliceras wooldridgei (Young). IMMEL AND SEYED-EMAMI, 1985, p. 98, Pl. 4, figs. 1-3.

Mantelliceras cressierense Renz, 1963. IMMEL AND SeYED-EMAMI, 1985, p. 101, Pl. 4, fig. 8.

Lectotype.-By the subsequent designation of Wright and Wright, 1951, p. 38 is GSM 7763, the original of Sharpe, 1857, PI. 20, fig. 3.

Collections. - Nineteen specimens: MHNG 19337 and MGL 42848, 42858 from Cheville, Morcles Massif, Valais; MHNG 1236 from Arberroz, MHNG 1274, 1275, 1277, 1315, 52489 from Lindars, all in the Platé Massif Haute-Savoie; MHNG 1326 from the Tête du Fer à Cheval, Haut-Giffre Massif, HauteSavoie.

Discussion. - This species is described in detail by Kennedy and Hancock (1971), Juignet and Kennedy (1976), and Wright and Kennedy (1984). The early whorls, which are compressed, densely ribbed, and generally lack a lateral tubercle, are easily distinguished from $M$. mantelli, $M$. cantianum, $M$. lymense, $M$. picteti and $M$. dixoni. Mantelliceras couloni is more difficult to separate when young, but generally has coarser inner ventrolateral tubercles and, in middle growth, prominent ventral clavi that increase in size through ontogeny, rather than declining, as in the present species.

Occurrence-Mantelliceras saxbii ranges throughout the Lower Cenomanian, but is common only in the middle of the substage, being represented by rather stout forms in the lower part of its range and by densely and flexuously ribbed forms in the upper part. It is widespread in southern England, the Boulonnais, Haute Normandie, Maine, Sarthe, and Provence in France and also in the Germanies, northern Spain, Switzerland, Poland, Roumania, Bulgaria, the Soviet Union, Iran north of the Zagros, north Africa, Angola, South Africa, and Madagascar.

\section{MANTELlicerAS LYMENSE (Spath, 1926b)}

Figure $12.7,12.8$

Ammonites Mantelli var. costata MANTELl, 1822, p. 289 (pars), Pl. 21, fig. 9, non Pl. 22, fig. 1 (=M. saxbii).

Mantelliceras batheri SPATH, 1926b, p. 431 (pars).

Eucalycoceras lymense SPATH, 1926b, p. 427, 431.

Mantelliceras costatum (Mantell). SzÁsz, 1983, p. 245, Pl. 10, fig. 3, Pl. 11, fig. 1, Pl. 14, fig. 1; IMMEL AND SeYed-EMAMI, 1985, p. 102, PI. 5 , fig. 2.

Mantelliceras lymense (Spath, 1926). WRIGHT AND KENNEDY, 1984, p. 102, Pl. 10, fig. 9, Pl. 22, figs. 1-6, Pl. 23, figs. 1-3, Pl. 31, figs. 1, 2 , Pl. 36, fig. 4, text-figs. 19, 24A, B, 26D, 28F-J; KENNEDY, JuIGNET, AND Wright, 1986, p. 27, Figs. 5a-f, 6d, e, 16e, f.

Mantelliceras thomeli Collignon, 1964. IMMEL AND SEYED-EMAMI, 1985, p. 102, Pl. 5, fig. 3 .

Lectotype.-By the subsequent designation of Wright and Kennedy, 1984, p. 102, the original of Pervinquière, 1907, Pl. 16, fig. 15, an unregistered specimen in the Sorbonne Collections, now in the Université Pierre et Marie Curie, Paris, and from north of Bargou, Tunisia. lais.

Collection. -MGL 42992 from Cheville, Morcles Massif, Va-

Discussion.-Mantelliceras lymense is the correct name for the more familiar $M$. costatum (Mantell, 1822), a junior primary homonym of Ammonites costatus Schlotheim, 1820, p. 68. It is easily distinguished from all other Mantelliceras species by its combination of an inflated whorl section and ribs with umbilical bullae and outer ventrolateral tubercles only beyond diameters of $25 \mathrm{~mm}$. Very small specimens may have an inner ventrolateral, but the species never develops a lateral tubercle. The single specimen in the present collections matches well with finer ribbed English specimens (e.g., Wright and Kennedy, 1984, Pl. 31, fig. 1).

Occurrence. - This species ranges throughout the Lower Cenomanian. It is recorded from southern England from Devon to Kent and Cambridgeshire; the Boulonnais, Haute Normandie, Sarthe, Maine, the Argonne, and Isère south to Cassis (Bouchesdu-Rhône) in France, Germany, Iran, Algeria, Tunisia, and Madagascar.

\section{MANTELLICERAS DIXONI Spath, 1926b}

Figures 11.1-11.4, 12.11, 12.12

Ammonites Milletianus d'Orbigny. J. DE C. SOWERBY, 1850, p. 359, Pl. 29, fig. 15.

Mantelliceras dixoni SPATH, 1926b, p. 427; KAPLAN, KELLER, AND WiedManN, 1984, Pl. 4, fig. 2; KenNedy, JUIGNET, AND Wright, 1986, figs. 1b, 3a-d, 18f, g, 19d, e, 20a-d, 21a-e, 22a-d.

Metacalycoceras Orbignyi Collignon, 1937, p. 45 (24), Pl. 10.

Mantelliceras charlestoni Kellum AND MiNTz, 1962, p. 272, Pl. 3, figs. 1, 2, Pl. 4, fig. 1.

Mantelliceras portalesi Kellum AND Mintz, 1962, p. 273, Pl. 4, figs. $3,4$.

Mantelliceras pseudohyatti Collignon, 1964, p. 73, Pl. 341, fig. 1525. Mantelliceras lateretuberculatum CollignoN, 1964, p. 90, PI. 348, fig. 1548, Pl. 349, fig. 1552.

Mantelliceras albanense BUSNARDO, 1966, p. 222, Pl. 12, figs. 1, 2. Mantelliceras beynense THOMEL, 1972, p. 41, Pl. 9, figs. 3-5.

Mantelliceras beynense baylei THOMEL, 1972, p. 42, Pl. 10, figs. 1, 2. Calycoceras salvadorense KEMPER AND WEBER, 1979, p. 11, Pl. 1, fig. 1 , text-fig. 4.

Mantelliceras n. sp. (aff. M. dixoni Spath). SzÁsz, 1983, p. 248, Pl. 11, fig. 2.

Mantelliceras dixoni Spath, 1926. WRIGHT AND KENNEDY, 1984, p. 124, Pl. 37, figs. 1-6, Pl. 38, figs. 2-5, Pl. 39, figs. 2-5, Pl. 40, figs. 1-5, text-figs. 21D-F, 22A-G, 23, 25E, J, 27M, R, S (with full synonymy). ?Mantelliceras gr. dixoni Spath. IMMEL AND SEYED-EMAMI, 1985, p. 103, Pl. 5, fig. 5.

Holotype. - By original designation, BMNH 33630, from the Lower Chalk of Sussex, the original of Ammonites milletianus J. de C. Sowerby (non d'Orbigny) 1850, Pl. 29, figs. 1, 2.

Collections. - Four specimens: MHNG 1217 and MGL 42847, 42853, 8375, all from Cheville, Morcles Massif, Valais.

Discussion. - MGL 42847 is an adult microconch $50 \mathrm{~mm}$ in diameter, and closely comparable to the holotype (Wright and Kennedy, 1984, Pl. 37, fig. 6), MGL 42853, a nearly complete macroconch $82 \mathrm{~mm}$, and MGL 8375 a complete macroconch $91 \mathrm{~mm}$ in diameter, are again similar to English specimens (e.g., Wright and Kennedy, 1984, Pl. 40, figs. 3, 4). The ribs are alternately long and short. The long ribs arise at umbilical bullae and are strong and bar-like on the inner flank. They flex back across the outer flank and bear outer ventrolateral clavi only, as do the shorter, intercalated ribs. All ribs are strongly developed across the tabulate venter. These specimens are of interest as the only firm evidence for the high Lower Cenomanian in the present faunas.

Occurrence. - This species is restricted to the Mantelliceras dixoni Zone of the upper Lower Cenomanian and is known from Cambridgeshire, Kent, Wiltshire, Dorset, and Devon in southern England, the Boulonnais, Haute Normandie, Sarthe, Jura, and Basses Alpes in France, Westphalia, German Federal Republic, Roumania, El Salvador, northern Mexico, and Madagascar, and possibly Iran north of the Zagros. 
Genus SHARPEICERAS Hyatt, 1903

(=Tlahualiloceras Kellum and Mintz, 1962)

Type species. - By original designation: Ammonites laticlavius Sharpe, 1855, p. 31, Pl. 14, fig. 1.

\section{SHARPEICERAS LATIClAVIUM (Sharpe, 1855)}

Figure 9.9, 9.10

Ammonites laticlavius SHARPE, 1855, p. 31, Pl. 14, fig. 1.

Sharpeiceras laticlavium (Sharpe). WRIGHT AND KENNEDY, 1987, p. 127, Pl. 41, fig. 4, text-figs. 29, 30, 34a (with full synonymy).

Holotype.-By monotypy, GSM 7755, from the Lower Chalk of Bonchurch, Isle of Wight, the original of Sharpe, 1855, Pl. 14, fig. 1 .

Collection.-One specimen: MHNG 1222, from Cheville, Morcles Massif, Valais.

Discussion. - The fragment from Cheville has a maximum preserved whorl height of $35 \mathrm{~mm}$. It is identical in style, strength, and density of ribbing to the holotype of the species. Sharpeiceras schlueteri Hyatt, 1903, is a close ally of $S$. laticlavium and adults of the two species have been confused by authors. Hyatt's form has a more evolute shell, the whorls increasing more slowly, while the ribbing is much coarser and more distant.

Occurrence. - The holotype is from the Lower Cenomanian of Bonchurch, Isle of Wight, and probably comes from the saxbii Subzone of the mantelli Zone or higher. Other English specimens also seem to come from above the base of the Cenomanian. The species also occurs in southeast France, Iran, Madagascar, and, perhaps Roumania.

\section{SHARPEICERAS SCHLUETERI (Hyatt, 1903)}

Ammonites laticlavius Sharpe. SCHLÜTER, 1871, p. 18 (pars), Pl. 7, figs. 4-8.

Sharpeiceras schlueteri HyATT, 1903, p. 111; WRIGHT AND KENNEDY, 1987 , p. 129 , Pl. 41 , figs. $1-3$, text-figs. $32,33,34$ d, e (with full synonymy).

Types. - Hyatt (1903, p. 111) based this species on Schlüter's Ammonites laticlavius (1871, p. 18, Pl. 7, figs. 4-8). The figured specimen on which subsequent authors based their interpretation of the species is missing, while the surviving specimens in the Schlüter collection belong to $S$. laticlavium.

Collections. -One specimen: MGL 42861, from the Lanche des Aux, Haut-Giffre Massif, Valais.

Discussion. - The specimen is distorted into an ellipse with a major diameter of $65 \mathrm{~mm}$. Coiling is quite evolute, with a slightly compressed rectangular whorl section. There are an estimated 26 ribs on the outer whorl. All are single and bear small umbilical bullae, small bullate mid-lateral tubercles, conical inner and stronger clavate outer ventrolateral tubercles. The specimen closely matches the fine juvenile figured by Kaplan et al. (1984, Pl. 2). This species is easily distinguished from $S$. laticlavium at this diameter by the more evolute coiling, lower whorls, fewer, coarser, mainly single ribs, and coarser tuberculation.

Occurrence.-This species is restricted to the Lower Cenomanian $M$. mantelli Zone and, in addition to the present record, is known from Sussex, Devon, and Cambridgeshire in England,
Haute Normandie, Sarthe, and Provence in France, the German Federal Republic, Peru, Angola, and Mozambique.

Subfamily ACANTHOCERATINAE de Grossouvre, 1894 Genus ACOMPSOCERAS Hyatt, 1903

(=Pseudacompsoceras Spath, 1925, p. 197)

Type species. -Ammonites bochumensis Schlüter, 1871, p. 1, Pl. 1, figs. 1-4, by original designation, =Ammonites renevieri Sharpe, 1857, p. 44, Pl. 20, fig. 2.

\section{ACOMPSOCERAS sp.}

Figure 14.7, 14.8

Collection.-One specimen: MGL 42877, from the Lanche des Aux, Haut-Giffre Massif, Valais.

Discussion. - This fragment shows only the venter, which is smooth and arched, flanked by clavate outer and conical inner ventrolateral tubercles, and part of a quite finely incised suture with subphylloid folioles. It is clearly an Acompsoceras but poor preservation precludes specific assignation. It is either $A$. re nevieri (Sharpe, 1857), which lacks a lateral tubercle, or $A$. inconstans (Schlüter, 1871) where a lateral is present.

\section{Genus ACANTHOCERAs Neumayr, 1875 (=Metacanthoplites Hyatt, 1900; \\ Alternacanthoceras Marcinowski, 1979)}

Type species. - By the subsequent designation of de Grossouvre, 1894, p. 27: Ammonites rhotomagensis Brongniart, 1822, p. 83,391 , Pl. 6 , fig. 2 .

\section{ACANTHOCERAS RHOTOMAGENSE (Brongniart, 1822)} Figure 15.12, 15.13

Ammonites rhotomagensis, Defr. Brongniart in Cuvier and Brongniart, 1822, p. 83, 391, Pl. 6, fig. 2.

Acanthoceras (Acanthoceras) rhotomagense rhotomagense (Brongniart, 1822). MarCINOWSKI, 1980, p. 305, Pl. 17, fig. 1, Pl. 18, figs. 1, 2. Acanthoceras rhotomagense (Brongniart). WRIGHT AND KENNEDY, 1987 p. 156, Pl. 42, fig. 8, Pl. 44, figs. 1-11, Pl. 45, figs. 1-5, Pl. 46, figs. $1-4,6$, Pl. 47, figs. 1, 2, Pl. 48, figs. 1, 2, Pl. 49, figs. 1, 5, 6, text-figs. $47-54,63 f-j, 64 a, b, 65 a-d, k, 66 a, f, g, j, 67 a-g, 68,69$ (with full synonymy).

Lectotype.-By the subsequent designation of $\mathrm{R}$. Douville, 1912, p. 238: the original of Brongniart, 1822, Pl. 6, fig. 2, now preserved in the Sorbonne Collections, housed in the Université Pierre et Marie Curie, Paris.

Collection.-One specimen: MHNG 19480 from Cheville, Morcles Massif, Valais.

Discussion. - The present specimen is a well-preserved juvenile $77 \mathrm{~mm}$ in diameter. All the visible ribs are primaries, numbering 12 on the last half whorl. The whorl section is compressed, with a whorl breadth to height ratio of 0.78 . The specimen is one of the common variants intermediate between sussexiense of Mantell, 1822, and subflexuosum of Spath, 1923 (see e.g. Kennedy and Hancock, 1970, Pl. 92, fig. 1). The specimen is easily distinguished from juvenile Acanthoceras jukesbrownei Spath, 1926a (p. 82; see Kennedy, 1971, p. 88, P1. 52, figs. 13, Pl. 53, fig. 1, Pl. 54, fig. 1, Pl. 55, figs. 1, 2), where primary

FIGURE 14-1-4, Mantelliceras saxbii (Sharpe, 1857). 1-3, MHNG 1315; 4, MHNG 1277. 5, 10, 13-15, 23, Hypoturrilites sp. 5, MHNG 23539; 10, MHNG 1306; 13, MHNG unreg; 14, MHNG 1219; 15, MHNG 13037; 23, MHNG 1312. 6, Hypoturrilites gravesianus gravesianus (d'Orbigny, 1842), MHNG 1323. 7, 8, Acompsoceras sp., MGL 42877. 9, 16, Mariella (Mariella) cf. gallienii (Boule, Lemoine, and Thevénin, 1906). 9, MHNG 1329; 16, MHNG 1330. 11, 12, 17, 18, Mariella (Mariella) sp. a. 11, MHNG 19254; 12, MHNG 1209; 17, MHNG 1210; 18, MHNG 19253. 19, Neostlingoceras sp.?, MHNG 1342. 20, 21, Anisoceras cherixi (Pictet and Renevier, 1866), holotype, MGL 894, the original of Pictet and Renevier, 1866, p. 103, Pl. 5, fig. 1. 22, 24, Anisoceras cf. perarmatum Pictet and Campiche, 1861, MGL 42868. All figures are natural size. 

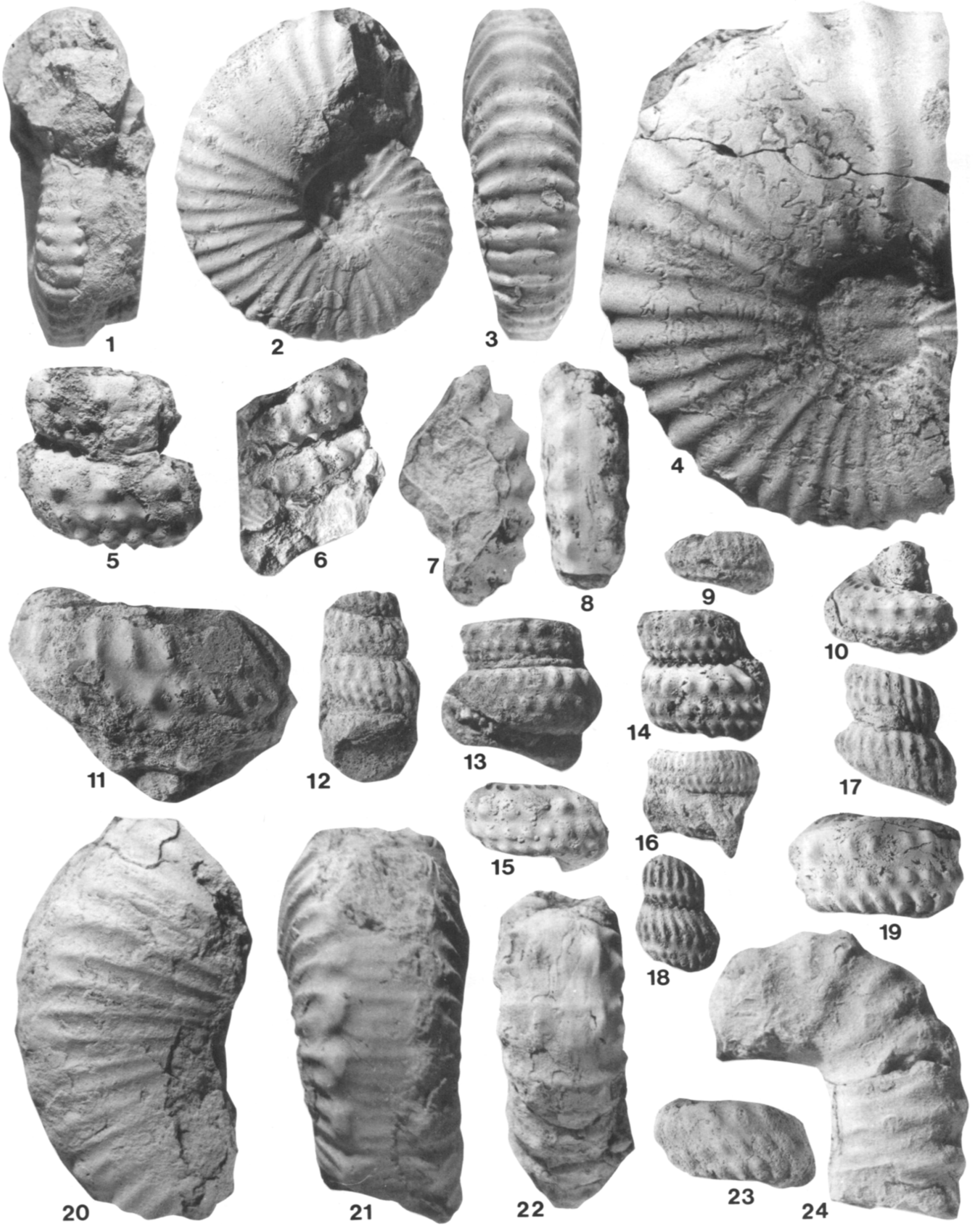
and secondary ribs alternate regularly at a stage where all ribs are long in rhotomagense.

Occurrence. - Acanthoceras rhotomagense is common only in the lower half of the Middle Cenomanian, the rhotomagense Zone. It occurs widely in southern and eastern England, across France from the Boulonnais to Provence, in northern Spain, Germany, Switzerland, Poland, Daghestan in the Caucasus, Crimea, north Africa, and Peru.

\section{Genus CUNnIngtoniceras Collignon, 1937}

Type species. - By original designation: Ammonites cunningtoni Sharpe, 1855, p. 35, Pl. 13, fig. 4.

\section{CUNNINGTONICERAS CUNNINGTONI (Sharpe, 1855) Figure 16.1-16.3}

Ammonites cunningtoni SHARPE, 1855, p. 35, Pl. 15, fig. 2. Cunningtoniceras cunningtoni (Sharpe). WRIGHT AND KENNEDY, 1987, p. 196, Pl. 52, fig. 2, Pl. 53, fig. 4, text-figs. 76-78 (with full synonymy).

Holotype.-By monotypy, BMNH 88704, from the Lower Chalk of Upton Scudamore, Wiltshire, England, the original of Sharpe, 1855, p. 35, Pl. 15, fig. 2.

Collections.-Five specimens: MHNG 19435, 19438 and MGL 8373, 8374, 42892 from Cheville, Morcles Massif, Valais. Discussion. - This species is characterized by its depressed whorl section, high umbilical wall, and broad venter, plus ornament of 10-13 distant, straight primary ribs with strong umbilical bullae, prominent inner ventrolateral horns, and weaker outer ventrolateral clavi that merge with the inner ventrolateral horn to form a massive ventrolateral horn at maturity. In earlymiddle growth siphonal tubercles are 2-3 times as numerous as the ventrolateral and are borne on a low siphonal ridge; those opposite the ventrolateral tubercles are linked to these by low transverse riblets, while short tuberculate riblets also intercalate. At maturity this multiple ventral ribbing and tuberculation declines.

Cunningtomiceras cunningtoni is easily separated from the $C$. inerme (Pervinquière, 1907), which also occur in the present collections. These have a more quadrate whorl section, lower expansion rate, more numerous primary ribs, up to 20 per whorl, less exaggerated ventrolateral tuberculation, and more numerous ventral riblets and siphonal tubercles.

Occurrence. - Where precisely dated this species characterizes the lower part of the Ancanthoceras rhotomagense Zone, the Turrilites costatus Subzone. It is known from Devon, Wiltshire, and Kent in England, from the Alpes-Maritimes in France as well as the present records, from Lleida, Spain, Switzerland, northern Iran, the U.S.S.R., Tunisia, Morocco, Nigeria, southern India, Madagascar, Japan, northern Australia, New Guinea, and, perhaps, Colorado and New Mexico in the U.S.A.

CunNingtoniceras INERme (Pervinquière, 1907) Figure 15.1-15.11, 15.14

Acanthoceras cunningtoni var. inermis PERVINQUIÉRE, 1907, p. 277.

Euomphaloceras inerme (Pervinquière). KENNEDY, 1971, p. 94, Pl. 59, fig. 6, Pl. 61, fig. 1, Pl. 62, fig. 1, Pl. 64, fig. 1; KAPLAN, KelleR, AND WiedMaNN, 1984, Pl. 15, fig. 6.

Acanthoceras (Acanthoceras) sowerbyi THOMEL, 1972, p. 147 (pars), non Pl. 79, figs. 8-10.

Acanthoceras vergonense THомеL, 1972, p. 158, Pl. 78, figs. 2-4, non Pl. 79, figs. 5-7.
Euomphaloceras inerme (Pervinquière). ZABORSKI, 1985, p. 40, fig. 44. Cunningtoniceras inerme (Pervinqière). WRIGHT AND KENNEDY, 1987, p. 194 , Pl. 52, fig. 1 , Pl. 53, fig. 6 , text-figs. $74,75,79$ (with fully synonymy).

Holotype.-By monotypy, GSM Geol. Soc. Collection no. 7754, from the Lower Chalk of Lewes, Sussex, the original of Sharpe, 1855 , p. 34 , Pl. 15, fig. 1.

Collections. - Nine specimens: MHNG 19434, 19436, 19437, 1214-1216, 1336, and MGL 8372, 42891, all from Cheville, Morcles Massif, Valais.

Description. - All our specimens are juveniles. Coiling is evolute, with a quadrate whorl section. There are 10 ribs per half whorl, straight and prorsiradiate, with strong umbilical bullae, large conical inner and smaller clavate outer ventrolateral tubercles, the latter linked by a broad rib. The outer ventrolateral clavi are linked by two or three low rounded ribs, each of which bears a rounded siphonal tubercle while additional short ventral ribs with a siphonal tubercle intercalate between the primary ribs. There is great variation in the ventral ornament, as can be seen from Figure 15.1-15.11, 15.14.

Discussion. - This distinctive species is much commoner than C. cunningtoni in the present fauna; differences from that species are indicated above.

Occurrence. - Where precisely dated this species characterizes the lower part of the Acanthoceras rhotomagense Zone, particularly the lower part of the Turrilites costatus Subzone. The geographic distribution includes Surrey, Sussex, Wiltshire, and Bedfordshire in England, Sarthe and Provence in France, Switzerland, Germany, as well as the present occurrence, and Japan.

\section{Superfamily TURRILITACEAE Gill, 1871 \\ Family ANISOCERATIDAE Hyatt, 1900 \\ Genus ANISOCERAS Pictet, 1854}

Type species. - Hamites saussureanus Pictet, 1847, p. 118, Pl. 13, figs. 1-4, from the Upper Albian of Mont Saxonet, Savoy.

\section{Anisoceras cf. A. Perarmatum \\ Pictet and Campiche, 1861 \\ Figure 14.22, 14.24}

Anisoceras perarmatus PICTET AND CAMPICHE, 1861, p. 65, Pl. 49, figs. $1-3,6,7$.

Anisoceras perarmatum perarmatum Pictet and Campiche. RENZ, 1968, p. 74, Pl. 13, fig. 5, Pl. 14, figs. 1-3, 5, text-figs. 27a, 28g (with full synonymy).

Lectotype.-By the subsequent designation of Renz, 1968, p. 74: the original of Pictet and Campiche, 1861, Pl. 49, fig. 1, from the Upper Albian of La Vraconne, Sainte Croix, Switzerland.

Collections. - Two fragments: MGL 42868-9, from Cheville, Morcles Massif, Valais.

Discussion. - The fragments are part of a curved section between the sub-parallel limbs of the late growth stages of this species. It shows coarse ribbing and tuberculation of the same general type as the lectotype of $A$. perarmatum (Renz, 1968, Pl. 13, fig. 5), with which it is compared. Anisoceras plicatile (J. Sowerby, 1819 , p. 281 , Pl. 234, fig. 1) is finely ribbed with more numerous intercalatories, and groups of two or three ribs linking tubercles. Anisoceras perarmatum is typically Upper Albian and has not been previously recorded from the Cenomanian. The

Figure 15-1-11, 14, Cunningtoniceras inerme (Pervinquière, 1907). 1, 11, MHNG 1214; 2, 3, MHNG 19436; 4, 9, MHNG 1215; 5, 6, MHNG 19437; 7, 8, MHNG 19434; 10, 14, MHNG 1336. 12, 13, Acanthoceras rhotomagense (Brongniart, 1822), MHNG 19430. All figures are natural size. 

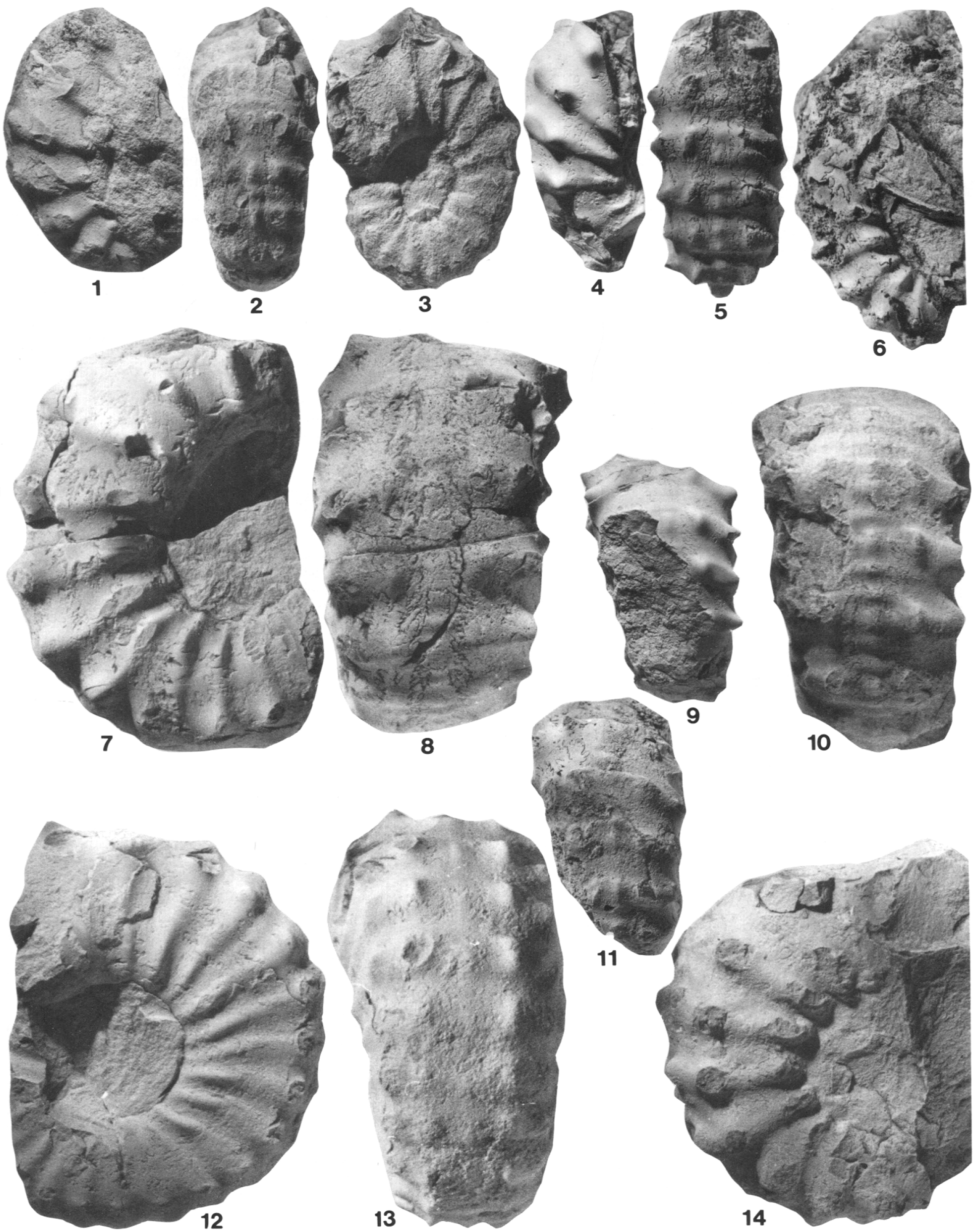
present specimens, from old collections, may possibly be remanié Albian material within the Cenomanian fauna at Cheville.

Occurrence. - Upper Albian Stoliczkaia dispar Zone of southern England, France, Switzerland, Sardinia, Tunisia, Nigeria, Madagascar, southern India, and Texas.

\section{ANISOCERAS Cherixi Pictet and Renevier, 1866} Figure 14.20, 14.21

Anisoceras(?) Cherixi Pictet AND Renevier, 1866, p. 103, Pl. 5, fig. 1.

Holotype. - By monotypy, the original of Pictet and Renevier, 1866, p. 103, Pl. 5, fig. 1, from the 'Couche Moyenne', Cheville, Morcles Massif, Valais.

Collection. - The holotype only, MGL 894.

Description. - The holotype is a large body-chamber fragment, lacking the dorsum and with a maximum whorl height in excess of $40 \mathrm{~mm}$. The whorl section appears to have been compressed, with broadly rounded flanks and a broad, flattened venter. The flanks are ornamented by narrow, sharply rounded ribs, separated by wide interspaces. They change in direction around the curvature of the fragment, but are feebly prorsiradiate and feebly concave on the outer flank. They are linked in pairs to long, blunt ventral clavi, with no intercalatories. Groups of three narrow, weaker ribs link the clavi across the venter with, again, no intercalatories.

Discussion. - Absence of a lateral tubercle separates $A$. cherixi from most other species of the genus, while the absence of nontuberculate intercalatories separates it from species such as $A$. exoticum Spath, 1939 (p. 555, Pl. 59, fig. 7, Pl. 60, fig. 4, Pl. 63, fig. 2, text-fig. 195) and A. campichei Spath, 1939 (p. 559, Pl. 63, figs. 6, 7, text-fig. 197). There are closer similarities to A. auberti (Pervinquière, 1907) (p. 85, Pl. 3, fig. 32); this species is based on a crushed composite mold showing one flank only, from the Cenomanian of Toukabeur, Tunisia. At the smallest diameter seen it shows pairs of narrow crowded flank ribs linked to ventral clavi, as in the present species, with additional intercalatories, while the final section, which is curved as in the holotype of cherixi, shows single ribs, each with a discrete weak ventral clavus.

Occurrence. - As for type.

Family TURRILITIDAE Gill, 1871

Genus TURRILITES Lamarck, 1801

Subgenus TURRILITES Lamarck, 1801

(=Euturrilites Breistroffer, 1953;

Turbinites Dubourdieu, 1953, non Martin, 1809)

Type species. - By original designation: Turrilites costatus Lamarck, 1801, p. 102.

TURRILITES (TURRILITES) COSTATUS Lamarck, 1801 Figure 17.26, 17.27, 17.29

Turrilites costata LAMARCK, 1801, p. 102.

Turrilites costatus Lamarck. DIENER, 1925, p. 81 (with synonymy).

Turrilites (Turrilites) costatus Lamarck. JUIGNET AND KENNEDY, 1976, p. 63, Pl. 9, figs. 15, 18, 19 (with synonymy); CHIRIAC, 1981, p. 75, Pl. 7, fig. 7; SeYed-EMAMI, 1982, p. 428, text-fig. 4, figs. 4, 5, 11; MARTINEZ, 1982, p. 161, Pl. 27, fig. 2; SzÁsz, 1982, p. 36, Pl. 4, figs. 1-5; KENNEDY AND JUIGNET, 1983, p. 47 , Figs. 25a-0, 26a, b, 27a-i, $28 \mathrm{a}, \mathrm{b}, \mathrm{d}$ (with synonymy).

Lectotype.-By the subsequent designation of Kennedy, 1971, p. 30: the specimen in the Lamarck collection from the Côte Ste Catherine, Rouen, Seine-Maritime, France, figured by Douvillé, 1904, p. 54a, fig. 1.

Collection.-Seven specimens: MHNG 19252, 1211, 1212 , 1251, 1252 and MGL 42870 all from Cheville, Morcles Massif,
Valais. MHNG 52485 from Arberroz, Platé Massif, Haute-Savoie.

Discussion. - This well-known species is relatively uncommon in the present collections, but the examples agree well with topotypes we have studied, as well as the extensive suite of specimens from Sarthe, France, recently illustrated by Kennedy and Juignet (1983). Of other species of Turrilites in the present collections, $T$. costatus is only likely to be confused with $T$. scheuchzerianus, described below. Adults are utterly distinctive, for $T$. scheuchzerianus have simple ribs only, extending across the whole of the exposed whorl face. In juvenile $T$. scheuchzerianus, however, the ribbing is interrupted at mid-flank (the Turrilites desnoyersi of authors), but never develops the tubercles that typify the present species, while the upper and lower whorl faces are smooth, rather than ribbed.

Occurrence. - Turrilites costatus is first recorded from the top of the Lower Cenomanian, but at least some of these records are based on T. (Mesoturrilites) boerssumensis Schlüter, 1876. It has a lower Middle Cenomanian acme, and ranges into the low Upper Cenomanian, with a near world-wide distribution including eastern, western and southern Europe, the U.S.S.R., north, west, and south Africa, Madagascar, the Middle East, Mongolia, southern India, Japan, New Guinea, northern Australia, Mexico, Texas and California in the U.S.A.

\section{TURRILITES (TURRILITES) SCHEUCHZERIANUS BoSc, 1801} Figure 17.23-17.25, 17.28, 17.30, 17.33, 17.42

Turrilites scheuchzerianus Bosc in Buffon, 1801, p. 190 (copy of Langius, 1708 , p. 112 , fig. 6); DIENER, 1925, p. 84 (with synonymy); SeYed-Emami, 1982, p. 430, text-fig. 4, figs. 6-8.

Turrilites (Euturrilites) scheuchzerianus Bosc. WIEDMANN, 1962, p. 192, Pl. 11, fig. 3 (with synonymy); Hiss, 1982, p. 190, figs. 7, 10.

Turrilites (Turrilites) scheuchzerianus Bosc. MARTINEZ, 1982, p. 162 , Pl. 27, figs. 3-5; KENNEDY AND JUIGNET, 1983, p. 52, text-figs. 27j, 28c, e, 29a-f, 30a (with synonymy); SeYed-EMami, FörSTER AND Mojtehedi, 1984, text-fig. 3, 3; KAPLAN, KelleR, AND WiedManN, 1984, PI. 5, fig. 4.

Collections. - Twenty-three specimens: MHNG 19263, 19267, $19269,1213,1250$, and MGL 8370, 42862-63, 42999-43001, 12721 from Cheville; MGL 43002-43004 from La Corday; MHNG 19264, 19266 from Ecuelle, all in the Morcles Massif, Valais. MHNG 19265 from the Chalets de Criou and MHNG 1290-1293 from the Pointe de l'Ecorchoir, both in the HautGiffre Massif, Haute-Savoie.

Discussion. - This well-known species has 19-21 ribs per whorl in typical forms. Juveniles show a distinct interruption of the rib at mid-flank (e.g., Figure 17.25, 17.33) with entire ribs characterizing the adult (Figure 17.23, 17.42). D'Orbigny $(1842, \mathrm{Pl}$. 146, figs. 1, 2) named specimens with interrupted ribbing Turrilites desnoyersi, and provided a reconstruction in which this feature is show persisting to maturity. It is indeed true that medium-sized specimens of the same whorl height have both interrupted and entire ribs, but these are juvenile macroconchs and adult microconchs, respectively.

Occurrence. - This species first appears in the upper part of the Lower Cenomanian and persists to the Upper Cenomanian with a near world-wide distribution including western, eastern and southern Europe, the U.S.S.R., north, east, west, and south Africa, Madagascar, southern India, Texas, Colorado, and California in the U.S.A., Mexico, Japan, and perhaps British Columbia.

Genus NeOstlingoceras Klinger and Kennedy, 1978

Type species. - By original designation: Turrilites carcitanensis Matheron, 1842, p. 267, P1. 12, fig. 4. 

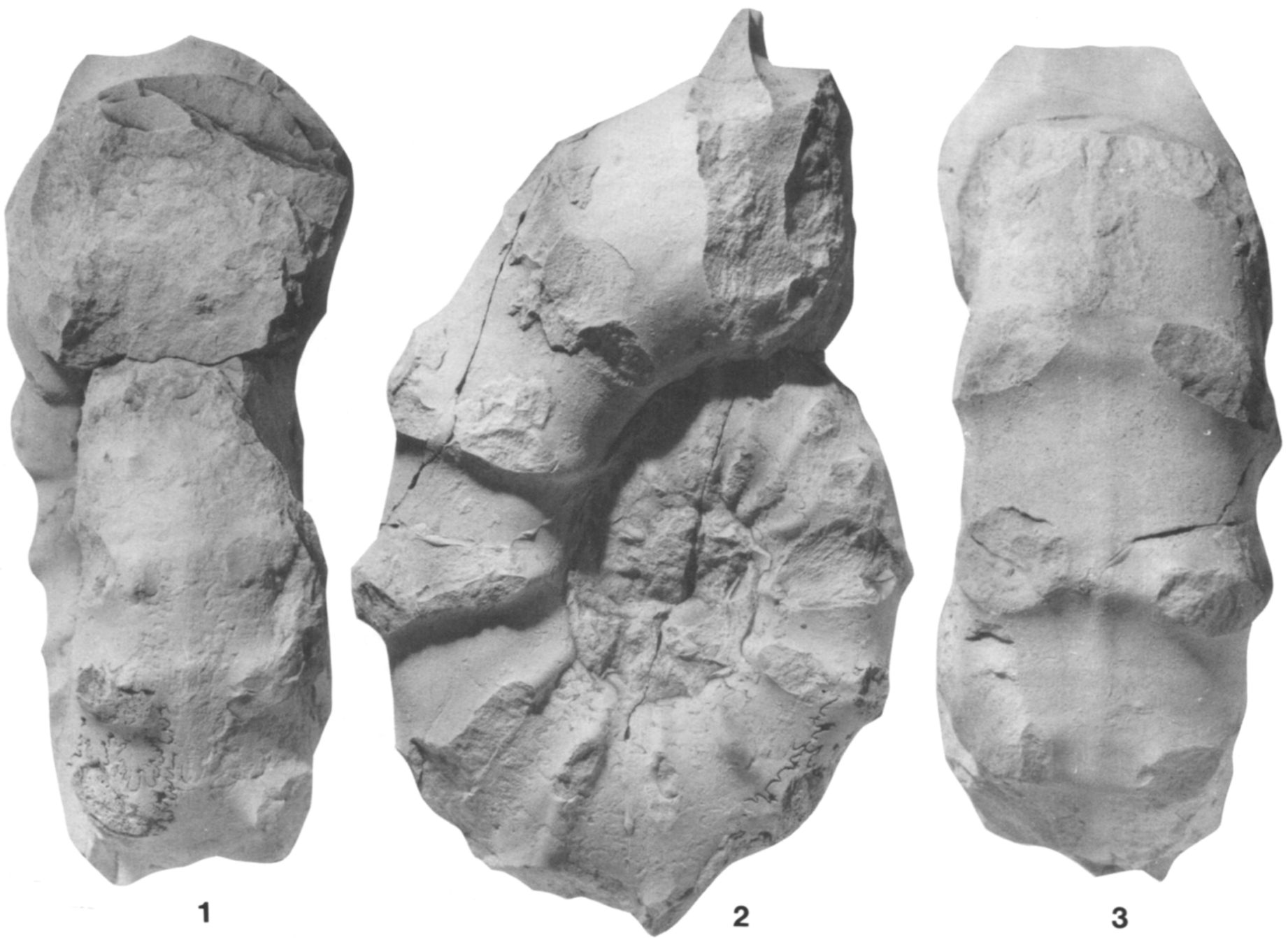

FIGURE 16-1-3, Cunningtoniceras cunningtoni (Sharpe, 1853), MHNG 19435. All figures are reduced $\times 0.7$.

\section{NEOSTLINGOCERAS CARCITANENSE (Matheron, 1842)}

Figure $17.31,17.32,17.36-17.38,17.40,17.41$

Turrilites carcitanensis MATHERON, 1842, p. 267, Pl. 12, fig. 4.

Neostlingoceras carcitanense (Matheron). MARCINOWSKI, 1980, p. 260, Pl. 4, fig. 16; KENNEDY AND JuIGNET, 1983, p. 43, fig. 22a, b, c (?) (with synonymy); SzÁsz, 1983, p. 239, Pl. 17, figs. 7, 8.

Hypoturrilites carcitanensis (Matheron). MARCINOWSKI AND RADWANSKY, 1983, Pl. 7, fig. 7.

Neostlingoceras aff. carcitanense (Matheron). KENNEDY AND JUIGNET, 1983 , p. 44, fig. 22d.

Holotype.-By monotypy: the original of Matheron, 1842, p. 267, Pl. 12, fig. 4.

Collections. - Nineteen specimens: MHNG 1298 from Avoudrues, Haut-Giffre Massif, Haute-Savoie; MHNG 1229, 1340a-d from Arberroz, MHNG 1278-79, 1314, 1324, 52478 from the Rochers des Fiz, MHNG 1325 from Barmerousse and MHNG 1296, 52488a-b from Lindars, all in the Plate Massif, Haute-Savoie. MGL 8365, 42882, 42884, 42885 from Cheville, Morcles Massif, Valais.

Discussion. - The present collection of this well-known species shows a comparable range of variation to that shown by both English (Kennedy, 1971) and French collections (Kennedy and Juignet, 1983), with specimens showing small, sharp tu- bercles (Figure 17.38), larger blunt ones (Figure 17.41), as well as those with (Figure 17.36, 17.37) and without feeble ribs on the upper part of the exposed whorl face (Figure 17.31, 17.38).

Occurrence. - This species is restricted to the lower $N$. carcitanense Subzone of the Lower Cenomanian Mantelliceras mantelli Zone with a wide geographic distribution in western Europe, Roumania, Yugoslavia, Poland, Iran, the Middle East, north Africa, Madagascar, Zululand, and perhaps southern India.

Genus HyPOTURRILITES Dubourdieu, 1953

Type species. - By original designation: TURRILITES GRAVESIANUS d'Orbigny, 1842, p. 596, Pl. 144, figs. 3-5.

\section{HYPOTURRILITES GRAVESIANUS GRAVESIANUS (d'Orbigny, 1842) \\ Figure 14.6}

Turrilites gravesianus D'ORBIGNY, 1842, p. 596, Pl. 144, figs. 3-5. Hypoturrilites gravesianus (d'Orbigny). SEYED-AMAMI AND ARYAI, 1981, p. 25, Pl. 6, figs. 1, 2; SEYED-EMAMI, 1982, p. 423, text-fig. 3, figs. 14; MARTINEZ, 1982, p. 159, Pl. 27, fig. 1; Hiss, 1982, p. 188, fig. 7; KENNEDY AND JUIGNET, 1983, p. 35, text-fig. 21d, e, i, j, 22g, 23b-g (with synonymy); SzÁsz, 1983, p. 238, Pl. 8, fig. 1. 
Types.-Kennedy (1971, p. 21) designated the original of d'Orbigny's Pl. 144, fig. 3 lectotype of the species, but the figure is a composite, based on two or more specimens.

Collections. - Ten specimens: MHNG 19281, 19282 and MGL 42854-57, 42874-75, 42988 from Cheville, Morcles Massif, Valais. MHNG 52481 from Sautet, Platé Massif, Haute-Savoie.

Discussion. - This distinctive species is represented by fragments only, referred to the species on the basis of their being two large and four small tubercles in a distance equal to the exposed whorl height. The closely allied $H$. tuberculatus (Bosc, 1801) has three large and 5-6 small tubercles in the same distance.

Occurrence. - This is chiefly a Lower Cenomanian species, with a few Middle Cenomanian records (the latter discussed by Kennedy and Juignet, 1983, p. 40). It has a wide geographic distribution in Europe, the U.S.S.R., northern Iran, north Africa, Zululand, Madagascar, and northern Australia.

\section{HYPOTURRILITES GRAVESIANUS BETAITRAENSIS Collignon, 1964 \\ Figure 17.35, 17.39}

Hypoturrilites gravesi d'Orbigny var. betaitraensis CollignoN, 1964, p. 13, Pl. 320, figs. 1387, 1388; KLINGER AND KENNEDY, 1978, p. 20 , Pl. 4, figs. A-C, Pl. 8, fig. F.

Holotype. - By original designation: the original of Collignon, 1964, PI. 320, fig. 1387, from the Cenomanian of Betaitra, Madagascar.

Collection. - One specimen: MHNG 19270 from the Chalets de Criou, Haut-Giffre Massif, Haute-Savoie.

Discussion. - The fragment is distorted, but shows clearly ribs and tubercles alternating on the upper whorl face as is diagnostic of the form betaitraensis.

Occurrence. - Lower Cenomanian of Madagascar and Zululand, in addition to the present records.

\section{HYPOTURRILITES sp.}

Figures 14.5, 14.6, 14.10, 14.13-14.15, 14.23, 17.34

Collections. - Ten specimens: MHNG 23539, 1219 from the Lanche des Aux, Haut-Giffre Massif, Valais and MHNG 13031309, 1320, 1323 from the Rochers des Fiz, Platé Massif, HauteSavoie.

Discussion. - This distinctive suite of Hypoturrilites are characterized by markedly loose coiling. There are 13-18 tubercles in the upper row and 20-22 in the lower three rows, so that in morphological terms, the group spans the Mariella (Mariella) to Hypoturrilites transition, some being very close to $M$. (M.) of the cenomanensis-lewesiensis group (e.g., Kennedy and Juignet, 1983, text-fig. 25p-r), others approaching $H$. tuberculatus. They are left in open nomenclature.

Genus MARIElla Nowak, 1916

Subgenus MARIELla Nowak, 1916

(=Paraturrilites Breistroffer, 1953;

Hemiturrilites Breistroffer, 1953;

Paraturrilites (Bergericeras) Wiedmann, 1962)

Type species. - By the original designation of Nowak, 1916, p. 10: Turrilites bergeri Brongniart, 1822, p. 99, 394, Pl. 7, fig. 3 .

MARIElla (MARIELla) cf. GALLIENII
(Boule, Lemoine, and Thévenin, 1906)

Figure 14.9, 14.16

compare:

Turrilites puzosianum d'Orbigny var. gallienii BOULE, LEMOINE, AND ThÉvenIN, 1906, p. 40 (60), Pl. 7 (14), figs. 4, 5.

Turrilites gallienii Boule, Lemoine, and Thévenin. Collignon, 1931, p. 89 (49), Pl. 9 (5), figs. 15, 16.

Paraturrilites gallienii (Boule, Lemoine, and Thévenin). Collignon, 1964 , p. 12, Pl. 320, figs. 1379, 1380.

Ostlingoceras gallienii (Boule, Lemoine, and Thévenin). KENNEDY, 1971, p. 27, Pl. 7, figs. 3, 4 .

Mariella (Mariella) gallienii (Boule, Lemoine, and Thévenin) evoluta Kinger AND KenNedy, 1978, p. 29, Pl. 3, figs. C, H, I, Pl. 6, figs. B, D, O, Pl. 7, figs. A, B, figs. 1E, 4E-G.

Collections.-Six specimens: MHNG 1329, 1330 from the Chalets de Criou, Haut-Giffre Massif, Haute-Savoie and MHNG $52479 \mathrm{a}-\mathrm{d}$ from the Rochers des Fiz, Platé Massif, Haute-Savoie.

Discussion. - These fragments have a low whorl height, the exposed outer face decorated by transverse ribs bearing three rows of tubercles, with a fourth concealed below the suture between whorls. They closely resemble the Ostlingoceras aff. gallienii of Kennedy, 1971, PI. 8, fig. 2.

Occurrence. - This is a rare species. In western Europe it occurs in the Mantelliceras mantelli Zone, Neostlingoceras carcitanense Subzone in Dorset, with an allied form present at a slightly higher level on the Devon Coast. It is also known from the Lower Cenomanian of Madagascar, while subspecies evoluta characterizes a low level in the Lower Cenomanian in Zululand.

Mariella (Mariella) sp. a Figure 14.11, 14.12, 14.17, 14.18

Collections. - Four specimens: MHNG 1209, 1210 from Cheville, Morcles Massif, Valais; MHNG 19253 from Avoudrues and MHNG 19254 from the Chalets de Criou, both in the HautGiffre Massif, Haute-Savoie.

Discussion. - These fragmentary specimens are ornamented by a long rib on the outer upper whorl face, terminating in a tubercle, with a second row of tubercles below and a third housed in notches at the lower whorl contact and a fourth, lying close to the third, concealed below the whorl suture. They resemble the $M$. (M.) cenomanensis (Schlüter, 1876)-lewesiensis (Spath, $1926 \mathrm{~b})$ group, although the long rib on the upper, outer whorl face of some (Figure 14.17, 14.19) is reminiscent of Turrilites (Turrilites).

Family BACULITIDAE Gill, 1871

Genus SCIPONOCERAS Hyatt, 1894

(=Cyrtochilus Meek, 1876, non Jakowlew, 1875; Cyrtochilella Strand, 1929)

SCIPONOCERAS ROTO Cieśliński, 1959

Figure 17.8-17.13, 17.16-17.23

FIGURE 17-1-5, Scaphites (Scaphites) obliquus. J. Sowerby, 1813. 1-3, MHNG 1242; 4, 5, MGL 42879. 6, 7, 14, 15, Sciponoceras baculoide (Mantell, 1822). 6, 7, MGL 42886a; 14, 15, MGL 42886b. 8-13, 16-22, Sciponoceras roto Cieśliński, 1959. 8, 9, MHNG 1341; 10, 11, MHNG $1310 ; 12,13$, MHNG 1233; 16, 17, MHNG 1316; 18, 19, MHNG 1317; 20, MHNG 1319; 21, 22, MHNG 1318. 23-25, 28, 30, 33, 42, Turrilites (Turrilites) scheuchzerianus Bosc, 1801. 23, MHNG 19262; 24, MHNG 1213; 25, MHNG 1290; 28, MHNG 19268; 30, MHNG 19266; 33, MHNG 1291; 42, MHNG 1216. 26, 27, 29, Turrilites (Turrilites) costatus Lamarck, 1801. 26, MHNG 1212; 27, MHNG 19252; 29, MHNG 1211. 31, 32, 36-38, 40, 41, Neostlingoceras carcitanense (Matheron, 1842). 31, MHNG 1325; 32, MHNG 1298; 36, MHNG 1314; 37, MHNG 1324; 38, MHNG 1296; 40, 41, MHNG 1229. 34, Hypoturrilites sp., MHNG 19282. 35, 39, Hypoturrilites gravesianus betaitraensis Collignon, 1964, MHNG 19270. All figures are natural size. 


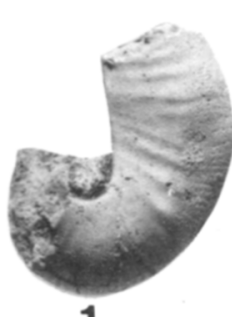

1

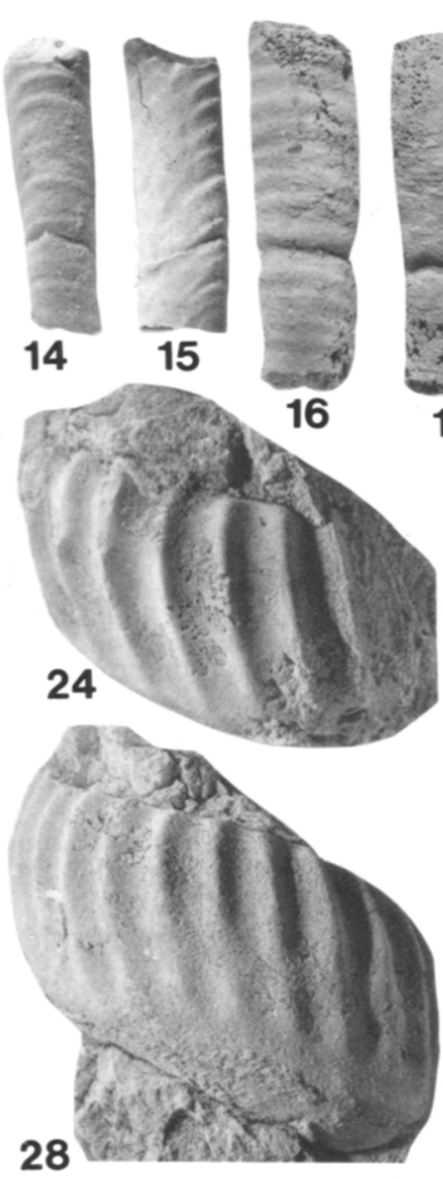

28

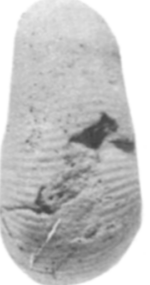

2

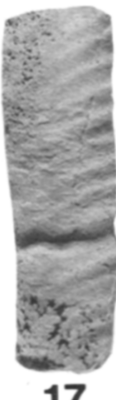

17

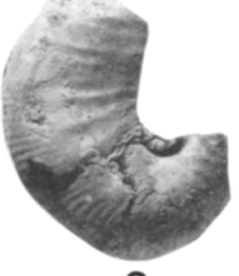

3
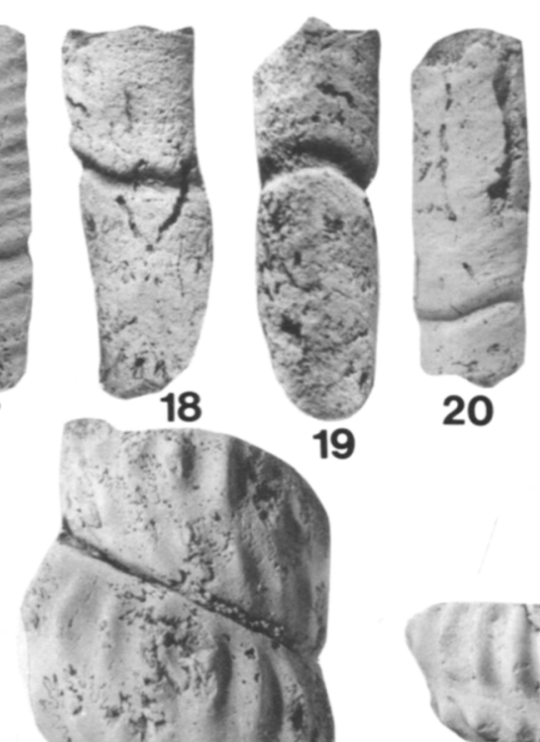

5

4
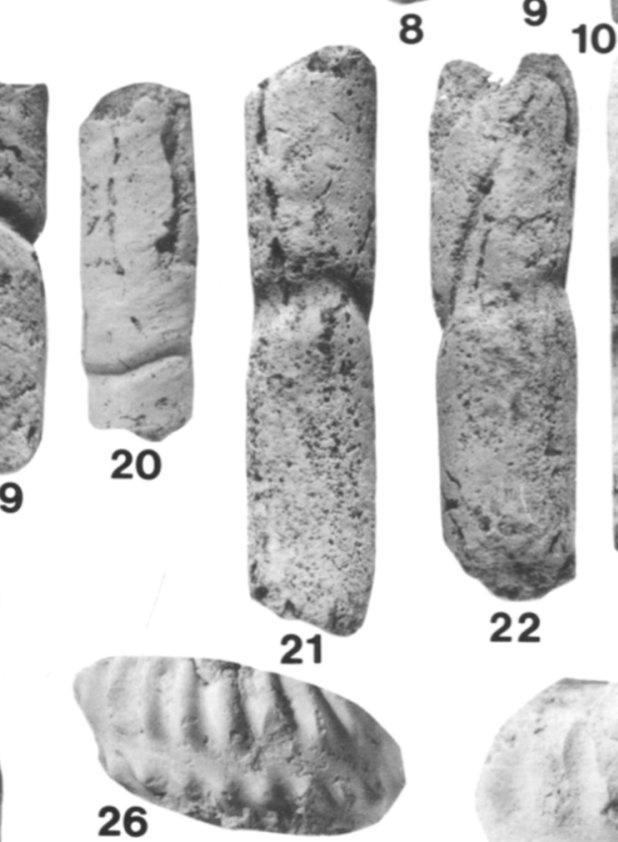

10
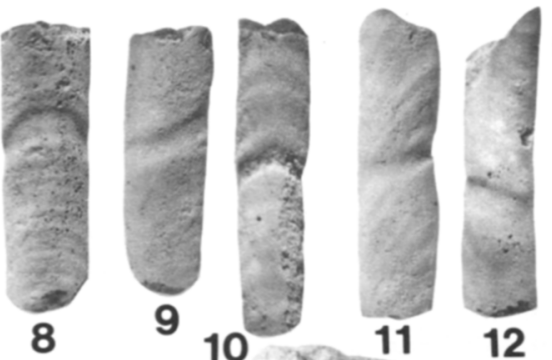

1213

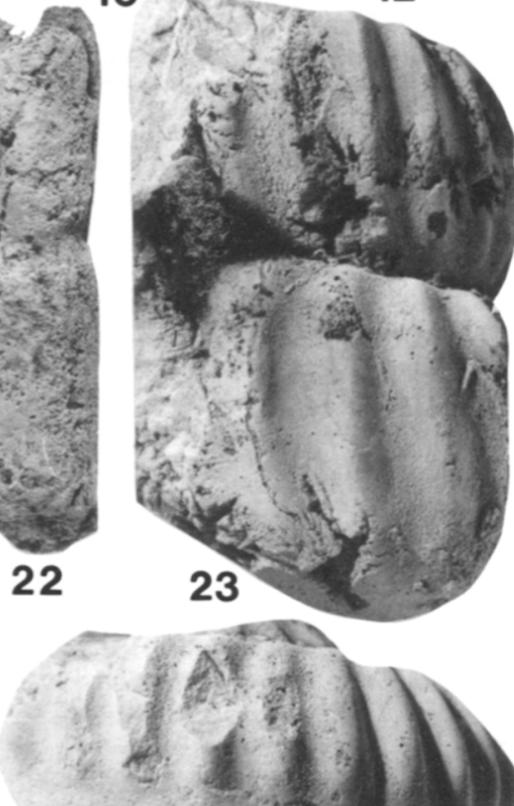

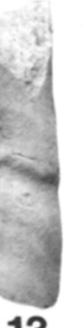
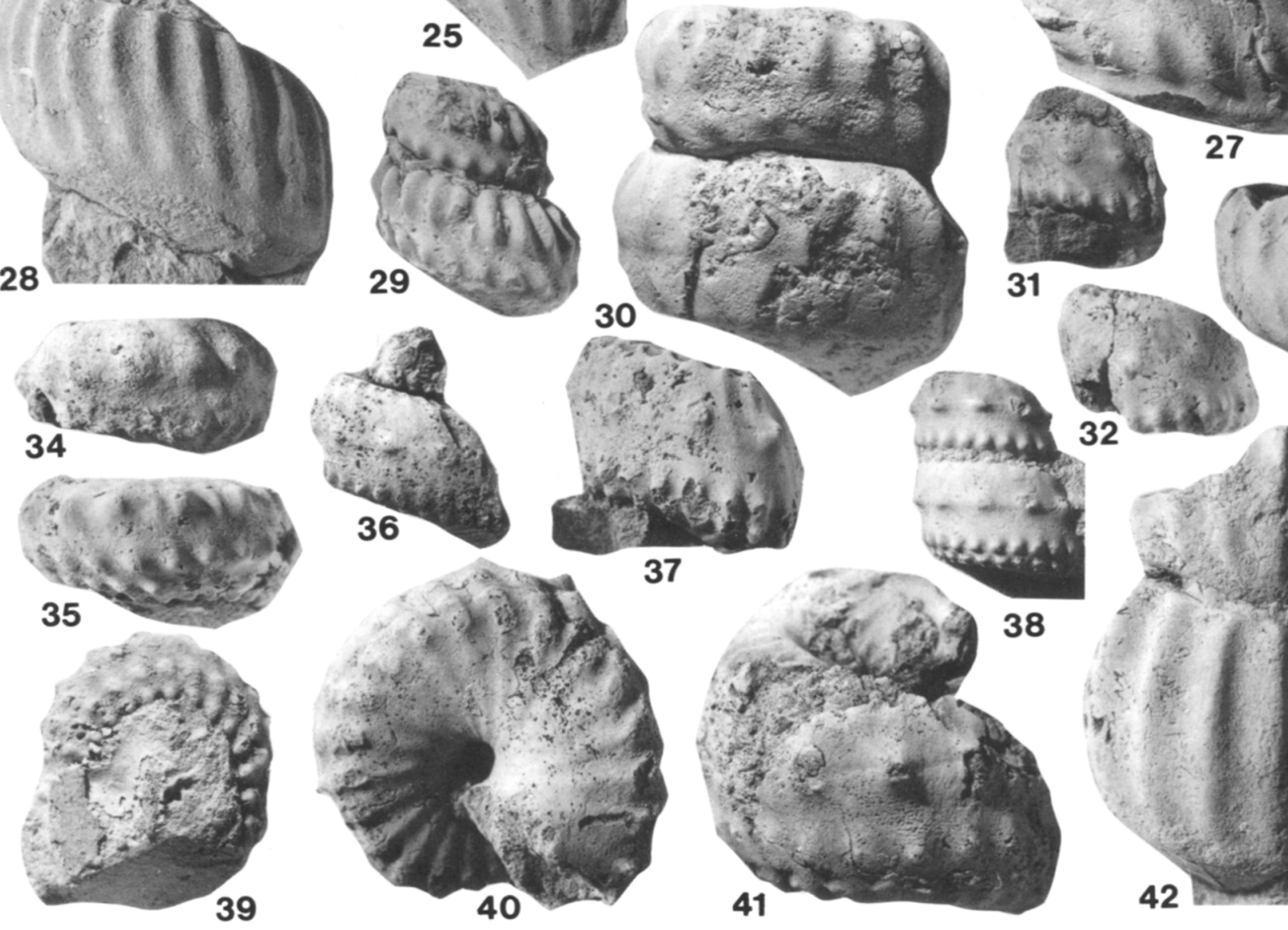

31

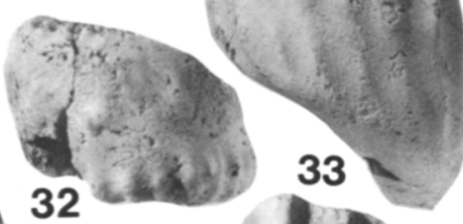

32
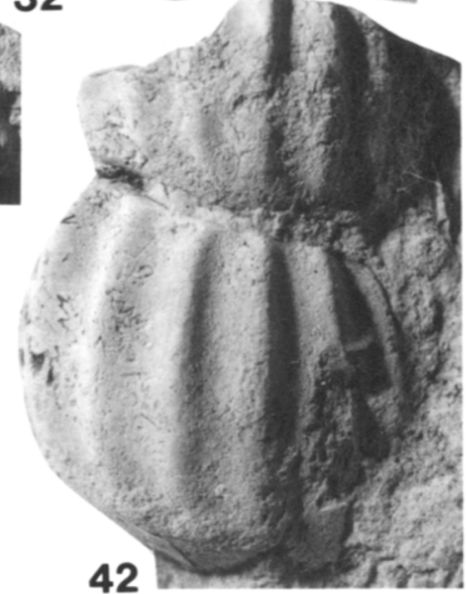
Sciponocers roto CIEŚLIŃSKI, 1959, p. 39, 75, 89, Pl. 4, fig. 10, text-fig. 14; Wright, 1963, p. 599; KENNEDY, 1971, p. 10, Pl. 3, fig. 7; HANCOCK, KENNEDY, AND KLAUMANN, 1972, P1. 81, fig. 8; KENNEDY AND KLINGER, 1975 , p. 277; MARCINOWSKI, 1980, p. 254, Pl. 3, figs. 14, 15.

Sciponocers cf. roto Cieśliński. KenNedy, Chahida, AND DJAfarian, 1979, p. 10, Pl. 1, fig. 4.

Types. - Cieśliński based this species on nine syntype fragments. We hesitate to designate a lectotype without seeing the original specimen.

Collections. -Twenty-one specimens: MHNG 1233 from Cheville, Morcles Massif, Valais; MHNG 1235, 1316-1319, 1322a-k; 1341 from the Rochers des Fiz and MHNG 1310, $1311 \mathrm{a}, \mathrm{b}$ from Arberroz, both in the Platé Massif, Haute-Savoie.

Discussion. - Sciponoceras roto is based on fragments with a circular to subcircular whorl section that are smooth between distant constrictions approximately three whorl heights apart. The present collection includes numerous fragments of this type (e.g., Figure 17.12, 17.13) plus those with faint lateroventral ribs and striae (Figure 17.10, 17.11, 17.14, 17.15). Also present are specimens with a circular cross section and very distant constrictions that bear strong lateroventral ribs (Figure 17.16, 17.17); these appear to be body chambers developing a comparable style of ornament to that seen in S. baculoide (Mantell, 1822) (e.g., Kennedy, 1971, Pl. 2, figs. 1-5) although the whorl section and distant constrictions separate the two. The direction of constrictions varies from markedly prorsiradiate to near transverse, but this is in part due to post-mortem distortion.

Also present in the collection are fragments with a compressed, oval whorl section, the whorl breadth to height ratio being as little as 0.8 , and thus resembling $S$. baculoide (fide Kennedy and Juignet, 1983 p. 19). These specimens have, however, the very distant constrictions typical of $S$. roto and although some have suffered post-mortem compression others appear undistorted, suggesting a wider range of whorl proportions than previously recognized in the species.

Occurrence. - This species is known from the low Lower Cenomanian of southern England, Germany, South Africa, and Mangyschlak, and is said to range throughout the whole of the Cenomanian in Poland (fide Marcinowski, 1980, p. 254).

\section{SCIPONOCERAS BACULOIDE (Mantell, 1822)}

Figure 17.6, 17.7, 17.14, 17.15

Hamites baculoide MANTELL, 1822, p. 123, Pl. 23, figs. 6, 7. Sciponoceras baculoide (Mantell). KENNEDY AND JUIGNET, 1983, p. 19, figs. 11a-y, 12a-bb, 13a-w, 14a-n (with full synonymy); KAPLAN, Keller, and WiedmanN, 1984, Pl. 5, fig. 2.

Lectotype.-By the subsequent designation of Kennedy (1971, p. 9): the larger specimen on BMNH 8612, a block figured by Mantell (1822, Pl. 23, fig. 6) from the lower Middle Cenomanian of Hamsey, Sussex.

Collections. - Four specimens: MGL 42866, 42993-42995 from Cheville, Morcles Massif, Valais.

Discussion. - Sciponoceras baculoide is a slender, slowly expanding species characterized by a compressed oval whorl section and a phragmocone with constrictions at intervals of 1.32.3 major diameters. In contrast, $S$. roto has an essentially circular whorl section with one constriction every three major diameters. Because of distortion, many fragmentary septate specimens of Sciponoceras in the present collections are best left in open nomenclature. Body chambers show prominent prorsiradiate flank ribs, convex on the ventrolateral region and strengthened into a scale-like projection on the venter.

Occurrence.-The species is typically Middle Cenomanian, but may range higher and lower. The geographic distribution extends from southern England through France and the German
Federal Republic. There are records from North America, north Africa, south India, Japan, and Madagascar that may or may not refer to this species.

Superfamily SCAPHITACEAE Gill, 1871

Family SCAPHITIDAE Gill, 1871

Genus SCAPHITES Parkinson, 1811

Subgenus SCAPHITES Parkinson, 1811

(=Anascaphites Hyatt, 1900; Jahnnites Hyatt, 1900;

Yezoites Yabe, 1910; Holcoscaphites Nowak, 1911)

SCAPHITES (SCAPHITES) OBLIQUUS J. Sowerby, 1813 Figure 17.1-17.5

Scaphites obliquus J. SowERBY, 1813, p. 54, Pl. 18, figs. 4-7.

Sc. (Scaphites) obliquus J. Sowerby. WIEDMANN, 1965, p. 417, Pl. 56, figs. $1-4$, text-fig. 3a, b (with synonymy); KeNNEDY, CHAHIDA, AND DuAfarian, 1979, p. 22, PI. 2, figs. 4, 5, 11; MARCINOWSKI, 1980, p. 264, Pl. 5, figs. 1-5; KENNEDY AND JUIGNET, 1983, p. 73, text-figs. 32a, b, 35a-c, 36a-h, 1-q, 37a-g, 38a-d, g-p; MARCINOWSKY AND RadwansKi, 1983, p. 7, figs. 3, 4; Kaplan, Keller, and WiEdManN, 1984, Pl. 4, fig. 5 .

Lectotype.-By the subsequent designation of Kennedy, 1971, p. 33; BMNH 43987a, the original of J. Sowerby, 1813, PI. 18, figs. 4-6.

Collections. - Two specimens: MHNG 1242 from Cheville and MGL 42879 from Ecuelle; both in the Morcles Massif, Valais.

Discussion.-MGL 42879 is a complete adult $24 \mathrm{~mm}$ long; the MHNG specimen is a body chamber $26 \mathrm{~mm}$ long. They show the typical weak flank ribs, bi- or trifurcating into secondary ribs over the venter, with additional intercalatories, and are easily distinguished from $S$. equalis J. Sowerby, 1813 (see Wiedmann, 1965, and Kennedy, 1971, for illustrations of the lectotype), which has strong flank ribs.

Occurrence. - This species ranges throughout the Lower and Middle Cenomanian. It is recorded widely from western and eastern Europe, the U.S.S.R., Balkans, Iran north of the Zagros, north and South Africa, Madagascar, and southern India.

\section{REFERENCES}

Atakbekyan, A. A. 1960. [Stratigraphy of the Upper Cretaceous deposits of Western Kopet Dag. In Geology and Oil-gasbearing in the Western Part of Central Asia]. Trudy Vsesoyuznogo Issledovat et skogo Geologicheskogo Institua (VSEGEI), n.s., 42:182-210 [in Russian].

BAYLE, E. 1878. Fossiles principaux des terrains. Explication de la Carte Géologique de la France, 4 (1), (Atlas), 158 pls. Service de la Carte Géologique détaillée, Paris.

Bosc, L. A. G. 1801. (An 13). In F. Roissy, Histoire Naturelle générale et particulière, des Mollusques, Animaux sans vertebrès et à sang blanc. Ouvrage faisant suite aux Oeuvres de Leclerc de Buffon, et partie du Cours complet d'Histoire naturelle, rédigé par C.S. SONNINI, membre de plusieurs Sociétés savantes. Continué par F. de Roissy. Chez Deterville, Paris, 448 p.

Boule, M., P. Lemonne, AND A. Thévenin. 1906-1907. Paléontologie de Madagascar III Céphalopodes crétacés des environs de DiegoSuarez. Annales de Paléontologie, 1:173-192 (1-20); 2:1-56 (21-76).

BOURBON, M. 1980. Évolution d'un secteur de la marge nord-téthysienne en milieu pélagique: la zone briançonnaise près de Briançon entre le début du Malm et l'Eocène inférieur. Unpubl. doctoral thesis, Université Louis Pasteur at Strasbourg, $580 \mathrm{p}$.

BreistrofFer, M. 1940. Révision des ammonites du Vraconien de Salazac (Gard) et considérations générales sur ce sous-étage albien. Travaus du Laboratoire de Géologie de l'Université de Grenoble, 22 (1938-39):17-171 (1-101 in separates).

. 1953. L'evolution des Turrilitidés Albiens et Cénomaniens. Compte Rendu Hebdomadaire des Séances de l'Académie des Sciences, Paris, (D), 234:2633-2635. 
Brongniart, A. 1822. Sur quelques terrains de la Craie hors du Bassin de Paris, p. 80-101. In G. Cuvier and A. Brongniart, Description Géologique des Environs de Paris, 3rd ed. Chez G. Dufour et E. d'Ocagne, Paris and Amsterdam.

BusNARDO, R. 1966. In R. Busnardo, R. Enay, G. Latreille and P. Rouquet, Le Crétacé moyen détritique à céphalopodes près de Poncin (Jura méridional). Travaux du Laboratoire de Géologie de l'Université de Lyon. n.s., 13:205-228.

CAROzzı, A. 1951. Contribution à l'étude micrographique de l'Albien de la région de Genève. Publications du Laboratoire de Géologie de l'Üniversite de Genève, n.s., 54, 45 p.

Charollais, J. 1966. Notes préliminaires sur le Crétacé moyen dans le massif des Bornes (Haute-Savoie). Laboratoire de Géologie de l'Universite de Genève, n.s., 153:1-3.

ChIRIAC, M. 1981. Amoniti cretacici din Dobrogia de Sud. Studiu biostratigraphic, Bucuresti, Academiei Republicii Socialiste România, $143 \mathrm{p}$.

CIEŚLIŃSKI, S. 1959. [The Albian and Cenomanian in the northern periphery of the Swiety Krzyz Mountains.] Instytut Geologiczny Prace, 28:1-95. [in Polish with English and Russian summaries].

Collignon, M. 1928-1929. Paléontologie de Madagascar, XV. Les céphalopodes du Cénomanien pyriteux de Diégo-Suarez, Annales de Paléontologie, 17(1928):139-160 (1-24); 18 (1929):1-56 (25-80).

- 1931. Paléontologie de Madagascar, XVI. La faune du Cénomanien à fossiles pyriteux du nord de Madagascar. Annales de $\mathrm{Pa}-$ léontologie, 20:43-104 (1-64).

- 1937. Ammonites Cénomaniennes du sud-ouest de Madagascar. Annales géologiques du Service des Mines de Madagascar, 8:29-72.

- 1964. Atlas des fossiles caractéristiques de Madagascar (Ammonites). XI Cénomanien. Service géologique, Tananarive, $152 \mathrm{p}$.

CoOper, M. R., AND W. J. Kennedy. 1987. A revision of the Puzosiinae (Cretaceous Ammonites) of the Cambridge Greensand. Neues Jahrbuch für Geologie und Paläontologie, Abhandlung, 174:105-121.

COQuAND, $H$. 1862. Géologie et paléontologie de la région sud de la Province de Constantine. Mémoires de la Société d'Emulation de la Provence, 2:1-341.

Crick, G. C. 1907. Cretaceous fossils of Natal, p. 161-250. In W. Anderson, Third and Final Report of the Geological Survey of Natal and Zululand. West, Newman and Co., London.

DelAMETTE, M. 1988. L'evolution du domaine helvétique (entre Bauges et Morcles) de l'Aptien supérieur au Turonien: séries condensées, phosphorites et circulations océaniques (Alpes occidentales francosuisses). Publications du Département de Géologie et Paléontologie de l'Université de Genève, 5, $316 \mathrm{p}$.

- H. Termier, AND G. Termier. 1983. Présence de l'Heteroastriidae Parkeria Carpenter, 1870 (Hydrozoa Milleporina) dans le Cénomanian de Haute-Savoie. Comptes Rendus de l'Académie des Sciences, Paris (2), 296:1351-1354.

Diener, C. 1925. Ammonoidea neocretacea. Fossilium Catalogus (1: Animalia), 29, 244 p.

Douvillé, H. 1890. Sur la classification des Cératites de la Craie. Bulletin de la Société Géologique de France (3), 18:275-292.

Douvillé, R. 1912. Ammonites rhotomagensis Defrance. In Brongniart, 1822. Palaeontologia Universalis, Fiche 238.

Dubourdieu, G. 1953. Ammonites nouvelles des Monts du Mellègue. Bulletin du Service de la Carte Géologique de l'Algérie. Première Série, Paléontologie, 16, $76 \mathrm{p}$.

Gidon, M. 1979. Carte géologique simplifiée des Alpes occidentales, du Léman à Digne. Didier-Richard and Bureau de Recherches géologique et minières (ed.).

Gill, T. 1871. Arrangement of the families of mollusks. Smithsonian Miscellaneous Collections, 227, 49 p.

Grossouvre, A. DE. 1894. Recherches sur la craie supérieur, 2, Paléontologie. Les ammonites de la craie supérieure. Mémoires de la Carte Géologique Détaillée de la France, 264 p.

Hancock, J. M., W. J. Kennedy, and H. KlaumanN. 1972. Ammonites from the transgressive Cretaceous on the Rhenish Massif, Germany. Palaeontology, 15:445-499.

HaUg, E. 1898. Études sur les Goniatites. Mémoires Paléontologiques de la Société Géologique de France, 7, 18, 112 p.

Hébert, [E.] AND [E. C. P. A.] Munier-Chalmas. 1875. Fossiles du bassin d'Uchaux. Annales des Sciences Géologique, 6:113-132.

Hiss, M. 1982. Ammoniten des Cenomans von Sudrand der westfäl- ischen Kreide zwischen Unna und Möhnesee. Paläontologisches Zeitschrift, 56:177-208.

Hyatr, A. 1894. Phylogeny of an acquired characteristic. Proceedings of the American Philosophical Society, 32:349-647.

1900. Cephalopoda, p. 502-604. In K. A. von Zittel, 18961900, Textbook of Palaeontology, transl. C. R. Eastman. Macmillan, London and New York.

- 1903. Pseudoceratites of the Cretaceous. Monographs of the United States Geological Survey, 44, $351 \mathrm{p}$.

Immel, H., AND K. Seyed-Emami. 1985. Die Kreideammoniten des Glaukonitkalkes (O. Alb- O. Cenoman) des Kolah-Qazi-Gebirges südöstlich von Esfahan (Zentral Iran). Zitteliana, 12:87-137.

JAKOWLEW, W. B. 1875. [Hemiptera and Homoptera of the Russian fauna]. Bulletin de la Société des Naturalites de Moscou, 49:248-285 [in Russian].

Juignet, P., AND W. J. KENNEDY. 1976. Faunes d'ammonites et biostratigraphie comparée du Cénomanien du nord-ouest de la France (Normandie) et du sud de l'Angleterre. Bulletin Trimestriel de la Société Géologique de Normandie et Amis du Muséum du Havre, 63:1-193

KaPlan, U., S. Keller, and J. WiedmanN. 1984. Ammoniten- und Inoceramen-Gliederung des Norddeutschen Cenoman. Schriftenreihe der Erdwissenschaftlichen Komissionen, 7:307-347.

Kellum, L. B., AND L. W. Mintz. 1962. Cenomanian ammonites from the Sierra de Tlahualilo, Coahuila, Mexico. Contributions from the Museum of Geology, University of Michigan, 13:267-287.

KEMPER, E., AND H. S. Weber. 1979. Über einige Cenoman-fossilien aus El Salvador und ihre biostratigraphische und Paläogeographische Bedeutung. Geologisches Jahrbuch, B37:3-29.

KenNEDY, W. J. 1971. Cenomanian ammonites from southern England. Palaeontology, Special Papers, 8, $133 \mathrm{p}$.

. 1984. Ammonite faunas and the 'standard zones' of the Cenomanian to Maastrichtian Stages in their type areas, with some proposals for the definition of stage boundaries by ammonites. Bulletin of the Geological Society of Denmark, 33:147-161.

, M. R. Chahida, AND M. A. DJafarian. 1979. Cenomanian cephalopods from the Glauconitic Limestone southeast of Esfahan. Acta Palaeontologica Polonica, 24:3-50.

-, AND J. M. HANCOCK. 1970. Ammonites of the genus Acanthoceras from the Cenomanian of Rouen, France. Palaeontology, 13 $462-490$

- AND - 1971. Mantelliceras saxbii, and the horizon of the Martimpreyi Zone in the Cenomanian of England. Palaeontology, 14: 437-454.

- AND - 1978. The mid-Cretaceous of the United Kingdom. Annales du Muséum d'Histoire Naturelle de Nice, 4 (for 1976):1-71. , AND P. JUIGNET. 1983. A revision of the Ammonite Faunas of the Type Cenomanian. I. Introduction, Ancyloceratina. Cretaceous Research, 4:3-83.

, AND - 1984. A revision of the ammonite faunas of the type Cenomanian. 2. The families Binneyitidae, Desmoceratidae, Engonoceratidae, Placenticeratidae, Hoplitidae, Schloenbachiidae, Lyelliceratidae and Forbesiceratidae. Cretaceous Research, 5:93-161.

,-- AND C. W. WRIGHT. 1986. A revision of the ammonite faunas of the type Cenomanian. 3. Mantelliceratinae. Cretaceous Research, 7:19-62.

- AND H. C. KLINGER. 1975. Cretaceous faunas from Zululand and Natal, South Africa. Introduction, Stratigraphy. Bulletin of the British Museum (Natural History) (Geology), 25:263-315.

KLINGER, H. C., AND W. J. KenNEDY. 1978. Turrilitidae (Cretaceous Ammonoidea) from South Africa, with a discussion of the evolution and limits of the family. Journal of Molluscan Studies, 44:1-48.

Kossmat, F. 1895-1898. Untersuchungen über die Sudindische Kreideformation. Beiträge zur Geologie und Paläontologie des Osterreichs, Ungarens und des Orient, 9, (1895):97-203 (1-107); 11, (1897): $1-46(108-153) ; 11,(1898): 89-152(154-217)$.

LamarCK, J. B. P. A. DE M. De. 1801. Système des Animaux sans vertèbrés. The author, Deterville, Paris, $432 \mathrm{p}$.

LANGUIS, C. 1708. Ammonis cornu. Historia lapidum figuratorium Helvetiae. Venetiia, 662 p.

MANTELl, G. A. 1822. The Fossils of the South Downs; or illustrations of the geology of Sussex. Lupton Relfe, London, $327 \mathrm{p}$.

MARCINOWSKI, R. 1970. The Cretaceous transgressive deposits east 
of Czestochowa (Polish Jura Chain). Acta Geological Polonica, 20: 413-449.

-1 1979. Alternacanthoceras subgen. nov. (Ammonoidea) and some remarks on other representatives of the genus Acanthoceras. Acta Geologica Polonica, 29:59-65.

- 1980. Cenomanian ammonites from the German Democratic Republic, Poland, and the Soviet Union. Acta Geologica Polonica, 30:215-325.

, AND A. RAdWANSky. 1983. The Mid-Cretaceous transgression onto the Central Polish Uplands (marginal part of the Central European Basin). Zitteliana, 10:65-95.

MaRTin, W. 1809. Petrifacta Derbiensia; or, Figures and Descriptions of the Petrifactions Collected in Derbyshire. White and Company, Wigan, etc., $28 \mathrm{p}$.

Martinez, R. 1982. Ammonoideas cretacicos del Prepirineo de la Provincia de Lleida. Publications de Geologia, Universidad Autonoma de Barcelona, 17, $197 \mathrm{p}$.

Matheron, P. 1842. Catalogue méthodique et descriptif des corps organisés fossiles du département des Bouches-du-Rhône et lieux circonvoisins. Marseille, 269 p.

MEEK, F. B. 1876. A report on the invertebrate Cretaceous and Tertiary fossils of the upper Missouri country. Report of the U.S. Geological Survey of the Territories, $9,629 \mathrm{p}$.

Neumayr, M. 1875. Die Ammoniten der Kreide und die Systematik der Ammonitiden. Zeitschrift der Deutschen Geologischen Gesellschaft, 27:854-942.

NowAK. 1911. Untersuchungen über die Cephalopoden der oberen Kreide in Polen. II. Teil. Die Skaphiten. Bulletin de l'Académie des Sciences de Cracovie, Classe des Sciences Mathématiques et Naturelles. Série B, Sciences Naturelles, B, (1911):547-589.

- 1916. Über die bifiden Loben der oberkretazischen Ammoniten und ihre Bedeutung für die systematik. Bulletin de l'Académie des Sciences de Cracovie, Classe des Sciences Mathématiques et Naturelles. Série B, Sciences Naturelles, (1916):1-10, 67.

OrbignY, A. D. 1840-1842. Paléontologie française: Terrains crétacés. 1. Céphalopodes. 1-120 (1840); 121-430 (1841); 431-662 (1842). Masson, Paris.

- 1850. Prodrome de Paléontologie stratigraphique universelle des animaux mollusques et rayonnés. Masson, Paris, 2,428 p.

ParkInson, J. 1811. Organic Remains of a Former World. Sherwood, Neily and Jones, London, 3, 479 p.

Parona, C. F., AND G. Bonarelli. 1897. Fossili Albiani d'Escragnolles, del Nizzardo e della Liguria occidentale. Palaeontographica Italica, 2:53-107 (1-55)

Pervinquière, L. 1907. Etudes de páleontologie tunisienne. 1. Céphalopodes des terrains secondaires. Carte géologique de Tunisie, de Rudeval, Paris, 438 p.

- 1910. Sur quelques ammonites du Crétacé algérien. Mémoires Paléontologiques de la Société Géologique de France, 17(2-3), 86 p. PicteT, F. J. 1847. In F. J. Pictet and W. Roux. 1847-1854, q.v.

- 1854. Traite de Paléontologie. 2, Cephalopodes, p. 583-716. Masson, Paris.

-, AND G. Campiche. 1858-1860. Description des fossiles du terrain crétacé des environs de Sainte-Croix, Part 2 (1), Description des fossiles. Matériaux pour la paléontologie Suisse, (2) Part 1:29-380. - AND E. RENEVIER. 1866. Notices géologiques et paléontologiques sur les Alpes Vaudoises et les régions environnantes. IV. Céphalopodes de Cheville. Bullétin de la Société Vaudoise des Sciences Naturelles, 9:117-138.

-, AND W. Roux. 1847-1854. Description des mollusques fossiles qui se trouvent dans les Grès Verts des environs de Genève. Mémoires de la Société de Physique et d'Histoire Naturelle de Genève, 11 (1847): 257-412; 12 (1849):21-151; 13 (1852):73-173; 14 (1854):279-341.

RENEVIER, E. 1866. Notices géologiques et paléontologiques sur les Alpes vaudoises et les régions environnantes. III. Environs de Cheville. Bulletin de la Société Vaudoise des Sciences Naturelles, 9:105116.

- 1890. Monographie des Hautes-Alpes Vaudoises. Matériaux pour la Carte Géologique de Suisse, 16e livraison, $562 \mathrm{p}$.

Renz, O. 1963. In O. Renz, H. Luterbacher, and A. Schneider, Stratigraphisch-paläontologische Untersuchungen im Albien und Cénomanien des Neuenberger Jura. Eclogae Geologicae Helvetiae, 56:10731116.
1968. Die Ammonoidea im Stratotyp des Vraconnien bei SainteCroix (Kanton Waadt). Schweizerische Paläontologische Abhandlungen, 87, $99 \mathrm{p}$.

REVIL, J. 1910-1913. Géologie des chaînes jurassiennes et subalpines de la Savoie. Mémoires de l'Académie de Savoie, 5, 926 p.

Rosset, J. 1957. Description géologique de la chaînes des Aravis entre Cluses et le Col des Aravis (Haute-Savoie). Bulletin du Service de la Carte Géologique de France, 247:341-387.

Schlotheim, E. F. voN. 1820. Die Petrefaktenkünde auf ihrem jetzigen Standpunkte durch die Beschreibung seiner Sammlung. Gotha, $437 \mathrm{p}$.

SCHLÜTER, C. 1871-1876. Cephalopoden der oberen deutschen Kreide. Palaeontographica, 21:1-4 (1871); 21:25-120 (1872); 24:1-144 (121264) + x (1876).

Semenov, V. P. [Benjamin] 1899. [Faune des dépots crétacés de Mangychlak et de quelques autres localités de la province Transcaspienne]. Travaux de la Société Impériale des Naturalistes de St.-Pétersbourg, Section de Géologie et Minéralogie, 1-178 [in Russian with French summary].

Seyed-Emami, K. 1982. Turrilitidae (Ammonoidea) aus dem Glaukonitkalk bei Esfahan (Zentraliran). Neues Jahrbuch für Geologie und Paläontologie Abhandlungen, 163(3): 417-434.

- AND A. A. ARYAI. 1981. Ammoniten aus dem unteren Cenoman von nordostiran (Koppeh-Dag). Mitteilungen der Bayerischen Staatsammlung für Paläontologie und Historische Geologie, 21:23-39.

- R. FörSTER, AND A. MoJTEHEDI. 1984. Ammoniten aus dem mittleren Cenoman von Nordost-Iran (Koppeh-Dagh). Neues Jahrbuch für Geologie und Paläontologie. Mönatshefte, 1984:159-172.

SHARPE, D. 1853-1857. Description of the fossil remains of Mollusca found in the Chalk of England. I, Cephalopoda. Palaeontographical Society Monographs, 68 p. 1-26 (1853); 27-36 (1855); 37-68 (1857).

SOWERBY, J. 1812-1822. The Mineral Conchology of Great Britain 1:pls. 1-9 (1812), pls. 10-44 (1813), pls. 45-78 (1814), pls. 79-102 (1815); 2: pls. $103-114$ (1815), pls. 115-150 (1816), pls. 151-186 (1817), pls. 187-203 (1818); 3: pls. 204-221 (1818), pls. 222-253 (1819), pls. 254-271 (1820), pls. 272-306 (1821); 4: pls. 307-318 (1821), pls. 319-383 (1822). The author, London.

SOWERBY, J. DE C. 1823-1846. The Mineral Conchology of Great Britain (continued). 4: pls. 384-407 (1823); 5: pls. 408-443 (1823), pls. 444-485 (1824), pls. 486-503 (1825); 6: pls. 504-544 (1826), pls. 545-580 (1827), pls. 581-597 (1928), pls. 598-609 (1829); 7: pls. 610-618 (1840), pls. 619-623 (1841), pls. 624-628 (1843), pls. 629643 (1844), pls. 644-648 (1846). The author, London.

- 1850. Description of the shells of the Chalk Formation. p. 346359. In F. Dixon, The Geology and Fossils of the Tertiary and Cretaceous Formations of Sussex. 1st ed. W. J. Smith, Brighton, 423 p. SPATH, L. F. 1922a. On the Senonian ammonite fauna of Pondoland. Transactions of the Royal Society of South Africa, 10:113-147.

1922b. On Cretaceous Ammonoidea from Angola, collected by Professor J. W. Gregory, D.Sc., F.R.S. Transactions of the Royal Society of Edinburgh, 53:91-160.

. 1923. On the ammonite horizons of the Gault and contiguous deposits. Summary of Progress of the Geological Survey (for 1922): 139-149.

- 1925. On Upper Albian Ammonoidea from Portuguese East Africa, with an appendix on Upper Cretaceous ammonites frm Maputoland. Annals of the South African Museum, 11:179-200.

. 1926a. On new ammonites from the English Chalk. Geological Magazine, 63:77-83.

1926b. On the zones of the Cenomanian and the uppermost Albian. Proceedings of the Geologists Association, 37:420-432.

1928. A monograph of the Ammonoidea of the Gault. Part 6. Palaeontographical Society Monographs, p. 207-266.

- 1939. A monograph of the Ammonoidea of the Gault. Part 13. Palaeontographical Society Monographs, p. 541-608.

STIEleR, K. 1922. Über Gault-und Cenoman-Ammoniten aus dem Cenoman des Cap Blanc Nez. Neues Jahrbüch für Mineralogie, Geologie und Paläontologie. Abhandlungen, 1922(2):19-44.

STRAND, E. 1929. Zoological and palaeontological nomenclatorial notes. Latvijas Universitates Raksti, 20:3-29.

SzÁsz, L. 1983. Contributions à l'étude des ammonites cénomaniennes de la Roumanie. Mémoires de l'Institu de Geologie et de Géophysique, Bucarest, 31:237-260. 
ThOMEL, G. 1972. Les Acanthoceratidae cénomaniens des chaines subalpines méridionales. Mémoires de la Société Géologique de France, (N.S.), 116, 204 p.

Tolun, N. 1948. Étude stratigraphique du Cénomanien de la nappe de Morcles. Unpubl. thesis no. 1073, Université de Genève, 84 p.

WiEDMANN, J. 1962. Ammoniten aus der Vascogotischen Kreide (Nordspanien). 1, Phylloceratina, Lytoceratina. Palaeontographica, 118A:119-237.

- 1965. Origin, limits and systematic position of Scaphites. $\mathrm{Pa}-$ laeontology, 8:397-453.

Wright, C. W. 1952. A classification of the Cretaceous ammonites. Journal of Paleontology, 26:213-222.

- 1963. Cretaceous ammonites from Bathurst Island, Northern Australia. Palaeontology, 6:597-614.

- AND W. J. KENNEDY. 1984. The Ammonoidea of the Lower Chalk. Palaeontographical Society Monographs, Part 1:1-126.

, AND - 1987. The Ammonoidea of the Lower Chalk. Palaeontographical Society Monographs, Part 2:127-215.
- AND E. V. WRIGHT. 1949. The Cretaceous ammonite genera Discohoplites Spath and Hyphoplites Spath. Quarterly Journal of the Geological Society of London, 104:477-497.

- AND E. V. WRIGHT. 1951. A survey of the fossil Cephalopoda of the Chalk of Great Britain. Palaeontographical Society Monographs: $1-40$.

YABE, H. 1910. Die Scaphiten aus der Oberkreide von Hokkaido. Beiträge zur Paläontologie des Österreichs, Ungarens und des Orients, 23:159-174.

ZABORSKI, P. M. P. 1985. Upper Cretaceous ammonites from the Calabar region, southeast Nigeria. Bulletin of the British Museum (Natural History) (Geology), 39:1-72.

ZITTEL, K. A. voN. 1895. Grundzüge der Palaeontologie (Palaeozoologie). R. Oldenbourg, Munich and Leipzig, 972 p.

ACCEPTED 23 OCTOBER 1990

J. Paleont., 65(3), 1991, pp. 465-480

Copyright (c) 1991, The Paleontological Society

0022-3360/91/0065-0465\$03.00

\title{
BIVALVES (MOLLUSCA) FROM THE MAUCH CHUNK GROUP (MISSISSIPPIAN, CHESTERIAN) OF NORTHERN WEST VIRGINIA AND SOUTHWESTERN PENNSYLVANIA
}

\author{
J.W. BUSANUS AND R. D. HOARE \\ Terra Vac, 806 Sylvia Street, West Trenton, New Jersey 08628 and \\ Department of Geology, Bowling Green State University, Bowling Green, Ohio 43403
}

\begin{abstract}
Bivalves comprise a major component of the faunules of the Mississippian Mauch Chunk Group in northern West Virginia and southwestern Pennsylvania. Twenty-eight species representing 22 genera have been recognized. Of these, three new species are proposed-Limipecten greerensis, Streblochondria tiltoni, and Prothyris (Prothyris) acuticarinata.
\end{abstract}

\section{INTRODUCTION}

$\mathrm{C}$ OLLECTIONS OF bivalves from five localities in the Mauch Chunk Group (Figure 1) form the basis for the present study. The localities (Appendix) coincide with the exposure of the Mauch Chunk outcrop belt along the Chestnut Ridge anticline and are limited to quarry operations in the area. Although many of the specimens are incomplete and poorly preserved, 28 species representing 22 genera are recognized amongst the several hundred specimens collected. It is believed that the following descriptions and illustrations are representative of the bivalve faunules present in the Mauch Chunk Group in this region. A preliminary study of the bivalves from equivalent and slightly younger strata in the Bluefield area of southern West Virginia and southwestern Virginia indicates more diverse faunules in that region than in the study area of this report.

\section{PREVIOUS WORK}

Mauch Chunk invertebrate faunas in the study area have been examined by Meek (1871), Tilton (1928, 1931), Coryell and Sohn (1938), Cooper (1941), Swales (1951), and Busanus (1974). Of these, only Coryell and Sohn and Busanus provided descriptive paleontology, the rest being mainly stratigraphical in nature.

In southern West Virginia, Girty $(1923,1926)$, Tilton (1931), Butts (1940-1941), Cooper (1944, 1948), Hickman (1951), and Englund et al. (1976) have provided discussions on the inver- tebrate faunas of the Upper Mississippian. More recently, Henry and Gordon $(1977,1979)$ and Gordon and Henry (1981) have provided preliminary evaluations of the Late Mississippian and Early Pennsylvanian invertebrate faunas from the area of the proposed stratotype section.

Studies containing Mississippian invertebrates in nearby geographical areas include those by Whitfield $(1882 \mathrm{~b}, 1891,1893)$, Morse (1911), Fagadau (1952), Hyde (1953), and Szmuc (1957) in Ohio; Lesley (1889-1890) and Benson (1934) in Pennsylvania; Cook (1912) and Brezinski (1989a) in Maryland; and Butts (1940-1941) in Virginia.

\section{STRATIGRAPHY}

The type section of the Mauch Chunk in Pennsylvania is primarily composed of nonmarine shales, siltstones, and sandstones. The lower portion is equivalent to the Greenbrier and Loyalhanna units (Edmunds et al., 1979). The Wymps Gap Limestone Member of the Greenbrier Formation in southwestern Pennsylvania is placed in the Meramecian by Edmunds et al. (1979, fig. 5). Busanus (1974) believed that the Wymps Gap is equivalent to the Union Limestone of northern West Virginia, which underlines the Mauck Chunk Group in the study area.

In northern West Virginia the Mauck Chunk was first detailed by Tilton (1928), who applied the stratigraphic designations as 